\title{
The Great Communicators and political reconstruction: A comparative study between President Ronald Reagan and President Barack Obama
}

\author{
Micheal D. Warren
}

A thesis submitted in fulfilment of the requirements for the degree of Master of Arts in Political Science at Victoria University of Wellington.

March 2013 


\begin{abstract}
Presidents come into office wanting to make America a better place, and Stephen Skowronek's recurring model of presidential authority is perfectly suited when comparing one president to another, across political time. President Ronald Reagan was categorised as a reconstructive president alongside Thomas Jefferson, Andrew Jackson, Abraham Lincoln and Franklin D Roosevelt, according to Skowronek's model; at the end of his first term, President Obama's has the potential to be remembered as the sixth president of reconstruction. While the nature of reconstruction has changed and has become more superficial with the ageing of the United States political system, Obama's reconstructive potential is no less potent than that of Jefferson, Jackson and Lincoln.

The passing of Health Care reform is Obama's biggest achievement of his presidency to date and is one of the biggest domestic reforms undertaken since the 1960s. Looking ahead to Obama's second term, further progress looks possible to enhance his reconstructive potential. If Obama can secure immigration reform, then he will give 12 million illegal immigrants the chance to come out from the shadows and work toward residency and legally live the American dream.

With the election and re-election of Obama by an emerging majority made up of women, African Americans, Hispanic Americans and young Americans, the Age of Reagan that existed, has now been replaced by a more diverse coalition. If a democrat can win the White House in 2016, it will truly mean that the Age of Obama has begun.

Obama's most potent legacy will become more evident in the years to come as many Americans will not remember what the unemployment rate was when he assumed office or what it was when he left office. The partisan bickering that dominated for much of Obama's first term will have faded into distant memory, but what will shine through from the Obama presidency is opportunity. Americans will never forget how Obama changed the limits of possibility for generations to come. Today there are ten year old African-American, Hispanic and Asian-American children all over the United States who believe that, because of the Obama presidency, they too can one day become president. That in itself is hugely reconstructive and by being elected President, Obama has achieved something more potent than any other reconstructive presidents could have ever achieved.
\end{abstract}




\section{Acknowledgements}

There are many people who provided support and assistance to me and I would like to thank them for their contribution to this thesis.

Firstly I would like to thank my supervisor Jon Johansson. Jon was always happy to meet to discuss ideas and is a huge source of knowledge on the American political system. I thoroughly enjoyed our regular meetings and I owe a huge amount of thanks and gratitude to Jon for all his assistance. He has taught me a great deal about politics and keeps challenging my ideas and conceptions with new thoughts and ideas, something I will forever be grateful for.

I also owe a huge amount of thanks to Professor Stephen Skowronek, whose two works have been extensively researched and used in the writing of this thesis. The Politics Presidents Make: Leadership from John Adams to George Bush and Presidential Leadership in Political Time: Reprise and Reappraisal are masterful publications that have formed the basis of this thesis. Skowronek's view of the presidency enables the reader to accurately compare one president to another across political time. These two works are exquisite pieces and I urge all those interested in American presidents to take time out to read them.

To my boss, Jo Goodhew, a huge thank you for the support and advice throughout this process. Jo has taught me a great deal about politics in a practical sense and I hope this thesis will expand your understanding about the United States political system.

To my parents, Bruce and Katrina Warren, a huge thanks for all your support, both financial, and for listening to my ideas and thoughts. They have been my rock throughout the research and writing of this thesis. To my siblings, Daniel, Marcus and Jasmin thanks for listening to my rambles and for putting up with me throughout this process. 
Thanks also to Grandpa and Nana, for their financial support throughout my University life. It has been a life saver and has meant me being able to get on with my studies without having to worry about my finances.

Finally I would like to give special thanks to my Grandpa (David Warren) who passed away suddenly mid-way through the writing of this thesis. I wrote to Grandpa just a couple of weeks before his passing, with a promise that I would dedicate my thesis to him. Poet, Henry Wadsworth Longfellow once said: When a great man dies, for years the light he leaves behind him, lies on the paths of men. My only hope is that my path is lit by grandpa, a great man and a real role model for us all.

Finally I hope this thesis enables readers to learn something about the American President and its place within the American Political system. 


\section{$\underline{\text { Table of Contents }}$}

Introduction

Chapter One: Presidential leadership theory - an overview $\quad \mathbf{8}$

$\begin{array}{ll}\text { Richard Neustadt and Presidential Power } & 9\end{array}$

James MacGregor Burns: Transactional vs. Transformational Leadership 16

James David Barber and the Presidential Character $\quad 18$

Cycles of Politics $\quad 22$

Chapter Two: The Politics Presidents Make - Skowronek Defined 28

The Politics of Reconstruction $\quad 32$

Thomas Jefferson Reconstruction 33

Andrew Jackson Reconstruction $\quad 35$

Abraham Lincoln Reconstruction $\quad 36$

FDR Reconstruction 38

The Politics of Disjunction $\quad 40$

John Quincy Adams Politics of Disjunction $\quad 41$

Hubert Hoover and politics of Disjunction 42

Jimmy Carter and the politics of Disjunction $\quad 43$

The Politics of Preemption $\quad 43$

The political preemption of Richard Nixon $\quad 44$

The political preemption of Bill Clinton $\quad 45$

$\begin{array}{ll}\text { The Politics of Articulation } & 47\end{array}$

Articulation of Theodore Roosevelt 48

Articulation of Lyndon Johnson 49

Skowronek Critiqued $\quad 51$

Chapter Three: The accent to the presidency - Reagan and Obama before the White House $\quad 56$

Ronald Reagan - From Film star to Governor 56

Barack Obama - From Hawaii to Community Organiser 60

Chapter Four: Paradigm Changing Elections $\quad 69$

1980 and the rebirth of the Republican Party $\quad 69$

$\begin{array}{ll}\text { The Republican Nomination } & 71\end{array}$

The Race for President $\quad 72$

2008 and Change comes to America $\quad 77$

$\begin{array}{ll}\text { The Democratic Nomination } & 77\end{array}$

The Race for President $\quad 82$ 
1984 and its Morning Again in America $\quad 87$

$\begin{array}{ll}\text { The Race for President } & 87\end{array}$

2012 and the new Democratic Coalition $\quad 90$

$\begin{array}{ll}\text { The Race for President } & 90\end{array}$

Reagan and Obama: Electoral Coalitions $\quad 95$

Reagan Coalition 95

$\begin{array}{ll}\text { Obama Coalition } & 98\end{array}$

Chapter Five: The Presidents as Leader - Reagan and Obama in Office $\quad 103$

Ronald Reagan and the Shining City on the Hill 103

Reagan's First Term: 1981-1985 103

Reagan's Second Term: 1985-1989 106

Barack Obama and the promise of 'Hope and Change' 111

Obama's First Term: 2009-2013 111

Obama and the Economic Recession $\quad 111$

The Passing of Historic Healthcare Reform 114

$\begin{array}{ll}\text { Obama and the World } & 117\end{array}$

Chapter Six: Is Obama the Next Reconstructive President $\quad 120$

Reagan: A Role Model for Obama? 121

Reagan: A Reconstructive President? $\quad 123$

Obama: Following in the Footsteps of Reagan? $\quad 126$

Response 1: Transformational leadership is still possible, and Obama might yet pull it off 129

Response 2: The reconstructive model of transformational leadership may work for some future president, but it was never likely to work for Obama 139

Response 3: The reconstructive model of transformational leadership is irrelevant. It has, in effect, been superseded by more purely progressive models of reform

Response 4: The reconstructive model of political transformation is still operative but only for the American Right 146

A Pre-emptive or reconstructive president? - Obama's future prospects at the beginning of his second term

Chapter Seven: Conclusion - The Great Experiment Moving Forward 152 


\section{List of Tables and Figures}

Table 1:

Political Eras

Table 2:

Hargrove's sequence of politics

26

Table 3:

Recurrent Structures of Political Authority

29

Figure 1:

1980 Presidential Election Results

77

Figure 2:

2008 Presidential Election Results

87

Figure 3:

1984 Presidential Election Results

91

Figure 4:

2012 Presidential Election Results

96 


\section{Introduction}

'All presidents come to power wanting to make America a better place and whether they succeed or fail, all presidents are formidable political actors. $^{\text {" }}$

Stephen Skowronek

On a historic November night in 2008, Barack Obama was elected as the forty-fourth president of the United States of America. Over the past four years, Obama has faced many challenges to his leadership. Obama was elected to the presidency at a time when America was fighting unpopular wars in Iraq and Afghanistan and the world economy was teetering on the brink of collapse. Obama's predecessor George W Bush was deeply unpopular, with approval ratings on a historically downward spiral. ${ }^{2}$ Rewind the clock 28 years and Ronald Reagan was also elected to the presidency in uncertain times. In 1980, American hostages were being held in Iran and the American economy was in the midst of the worst recession since the Great Depression. Incumbent President Jimmy Carter was deeply unpopular and Reagan was elected in a landslide. Both Obama and Reagan entered the White House on the back of a pervasive repudiation of a failed predecessor and, despite coming from parties on opposite sides of the political spectrum, they share many similarities.

In order to compare President Obama to President Reagan, one must first build a theoretical approach. Chapter One will focus on a general discussion of presidential leadership theory. Over time, academics have developed theories to compare and contrast presidents; the first to be discussed is Richard Neustadt. Neustadt's, Presidential Power and the Modern Presidents, is an important first step when analysing presidential

\footnotetext{
${ }^{1}$ Stephen Skowronek, The Politics Presidents Make: Leadership from John Adams to Bill Clinton, (Cambridge: Harvard University Press, 1997), p.3.

2 Gallup Polling, 'Presidential Job Approval Centre', 2011, http://www.gallup.com/poll/124922/Presidential-Approval-Center.aspx (28 December 2011).
} 
leadership and his long-standing theory focuses on three distinctive attributes that a president must possess to be successful. They are: their formal use of powers, their professional reputation and their public prestige. ${ }^{3}$ James MacGregor Burn's concept of transactional vs. transformational leadership is not specifically focussed on presidential leadership and can be applied to leadership in general, but is an important theoretical step to explore before analysing in greater detail Stephen Skowronek's recurring structure of presidential authority. ${ }^{4}$ The third theory that will be discussed in Chapter One introduces into the discussion the character of the president, and James David Barber's model describes four types of presidential character. They are: active-positive, activenegative, passive-positive and passive-negative. ${ }^{5}$ It is important to touch on Barber's theory as Skowronek argues that it takes a person of rare character and political skill to control the political system and manipulate government in their favour. ${ }^{6}$

The second section of Chapter One will further pre-empt Skowronek's recurrent structure of presidential authority by discussing cycles of politics. Cycles occur naturally in all forms of life and Arthur Schlesinger; his son Arthur Schlesinger Junior and Erwin Hargrove have reached across presidential history to attempt to bring a sense of rhythm to what at best is a changing role. The Schlesinger's theory argues that there are distinctive political eras in United States history. Those eras are the liberal or progressive periods and the conservative periods. ${ }^{7}$ Hargrove has developed a more refined structure compared to the Schlesinger's theory by arguing that there are three distinctive types of presidential periods: of preparation, of achievement and of consolidation. ${ }^{8}$

\footnotetext{
${ }^{3}$ Richard E. Neustadt, Presidential Power and the Modern Presidents: The Politics of Leadership from Roosevelt to Reagan, (New York: Free Press, 1990).

${ }^{4}$ James MacGregor Burns, Leadership, (New York: Harper and Row, 1978), p.4.

${ }^{5}$ James David Barber, The Presidential Character: Predicting Performance in the White House Fourth Edition, (New York: Pearson Education Inc., 2009), p.1.

${ }^{6}$ Stephen Skowronek, The Politics Presidents Make: Leadership from John Adams to Bill Clinton, p.76.

${ }^{7}$ Arthur M. Schlesinger Jr., The Cycles of American History, (New York: Mariner Books, 1999).

${ }^{8}$ Erwin C. Hargrove, The President as Leader: Appealing to the Better Angels of our Nature, (USA: University of Kansas, 1999).
} 
Following from the general discussion on presidential leadership theory, Chapter Two will analyse Stephen Skowronek's recurring structure of presidential authority. Skowronek argues that there are four recurring structures of presidential authority in his landmark 1993 publication, The Politics Presidents make: reconstruction, disjunction, pre-emption and articulation. While the present thesis is focussed on two of the four structures that Skowronek identifies: reconstruction and pre-emption, it is still important to discuss disjunction and articulation as alternative structures. Skowronek also argues that there are four distinctive eras in American history: the Patrician Era (1789-1832), the Partisan Era (18321900), the Pluralist Era (1900-1972) and the Plebiscitary Era (1972present). Chapter Two will provide a sweeping overview of his theory by threading together presidencies from the past 200 years of history. Ultimately, Stephen Skowronek's theory will be used to compare and contrast Reagan and Obama and provide an overview of Obama's presidential leadership. Skowronek's recurring structure of a presidential authority model stands out over other models because of its simplicity and the fact that his theory can be applied to every president in American history. Skowronek's historical approach has the ability to compare one president from the $21^{\text {st }}$ century to a president from the early $19^{\text {th }}$ century. When reaching across political time to compare one president to another, it is important to use a historical approach, hence the choice of Skowronek. Skowronek's model is compared to Schlesinger and Hargrove's ahistorical approach, whose model is more applicable to those presidents who served during the $20^{\text {th }}$ century. Chapter Two will also provide a critique of Skowronek's theory, arguing chiefly that his recurrent structure of presidential authority has the potential to create a deterministic and overly simplistic view of the presidency.

Chapter Three will focus on the biographical details of Reagan and Obama's backgrounds. Reagan was elected to the office at the grand old age of 69, making him the oldest man to be elected to the presidency, following a career as a B grade film star and Governor of California. In comparison, Obama was only 47 when he was elected to the presidency. 
The first African American to be elected as president, Obama was born the son of a Kenyan father and an American mother in Hawaii on 4 August 1961. Obama would spend his childhood living in Hawaii and Indonesia with his mother, after his parents divorced. Obama would go on to become a community organiser in Chicago before attending Harvard Law School and becoming the first African American president of the Harvard Law Review. Before becoming president, Obama was an Illinois State Senator from 1997-2004, before becoming the Junior Senator from Illinois following the 2004 election.

Chapter Four will analyse how Reagan and Obama won the presidency. The presidential elections of 1980 and 2008 were historic and paradigmchanging elections in America. Reagan replaced Jimmy Carter in 1980 and in 2008 George W Bush's two terms were completed and Obama was swept to power on a message of hope and change. Reagan defeated Carter by winning 489 electoral votes compared to only 49 for Carter. Reagan held power in 1984 in a massive landslide by winning 49 states and claiming 525 electoral votes compared to only 13 for Democratic candidate Walter Mondale. Reagan won $59 \%$ of the popular vote, compared to only $41 \%$ for Mondale. ${ }^{9}$ In 2008 Obama defeated Republican candidate John McCain by winning 365 electoral votes compared to 173 for McCain. Obama won $52.9 \%$ of the popular vote and carried 28 states, with McCain winning $45.7 \%$ of the vote and 22 states. Obama would win re-election in 2012 defeating Republican candidate, Mitt Romney. Obama won 332 electoral votes and $51 \%$ of the vote compared to 206 electoral votes and $47.2 \%$ of the vote for Romney. Obama became the first re-elected president in more than a century whose share of the vote was smaller a second time around. ${ }^{10}$ Chapter Four will conclude with an analysis of the Reagan and Obama electoral coalition as it links back to Skowronek's reconstructive theory.

\footnotetext{
${ }^{9}$ Yanek Mieczkowski, The Routledge Historical Atlas of Presidential Elections, (New York: Routledge, 2001).

${ }^{10}$ David von Drehle, 'For Obama, Survival is the New Winning,' November 72012 , www.swampland.time.com/2012/11/07/for-obama-survival-is-the-new-winning.html, (Assessed 6 January 2013).
} 
Once the thesis has established how Obama and Reagan were elected to the White House, Chapter Five will focus on the achievements and scandals that have surrounded the Reagan and Obama presidencies. Reagan led the economic recovery of the 1980s and was a strong advocate of supply-side economics. Reagan has also been widely credited with helping end the Cold War, while his second term would be overshadowed by the Iran-Contra Affair. Despite this scandal, Reagan is revered in the eyes of conservatives and many other Americans; since his death in 2004 his reputation and standing in American history has only grown. In comparison, Obama's first term as president was dominated by three key issues: the economic recession, the passing of historic Healthcare Reforms and the continuing wars in Iraq and Afghanistan.

As stated, Obama was first elected under the mantra of 'Hope and Change' and was determined to build a new America. Skowronek defines Reagan as a president of reconstruction and Chapter Six will first describe Obama's thoughts towards Reagan's leadership and will then analyse the nature of Reagan's reconstruction and argue that, compared to his predecessors, Reagan's reconstruction is superficial and more rhetorical in nature. Reagan was successful in creating a paradigm shift and creating a new and enduring governing coalition and this Chapter will focus on the central hypothesis of this thesis. That hypothesis is that despite the comparisons with Reagan, it remains to be concluded whether or not Obama will be categorised as the sixth president of reconstruction under Skowronek's recurring model of presidential authority. This thesis will argue that Obama was given much latitude to frame the debate following his election to the presidency in 2008. Obama was successful in passing economic stimulus and historic but unpopular healthcare reforms. Like Reagan, Obama has been successful in creating a new governing coalition, but it remains to be seen how enduring that coalition made up of Hispanics, African Americans, the young and women will actually be. The 2016 presidential election and the Democratic candidate's fortunes will provide further evidence to answer this question. Obama has not been given a blank check by Washington to carry out his platform and has at 
every step of the way faced stiff opposition by the Republican Party and the off-shoot Tea Party that was established in response to Obama's healthcare reforms. Skowronek identifies in his 2011 publication, Presidential Leadership in Political Time: Reprise and Reappraisal, four possible outcomes to the Obama presidency. Those four options are: i) that transformational leadership is still possible, and Obama might yet pull it off; ii) that the reconstructive model of transformational leadership may work for some future president, but it was never likely to work for Obama; iii) that the reconstructive model of transformational leadership is irrelevant and has, in effect, been superseded by a more purely progressive model of reform; and iv) the reconstructive model of political transformation is still operative, but only for the American right. ${ }^{11}$ Overall Chapter Six will expand on the four possible outcomes that Skowronek has developed to paint an early picture of where Obama will eventually be placed on Skowronek's recurring model of political authority. The passing of time will eventually give a greater perspective on the legacy of the Obama presidency; of whether he will be remembered as a pre-emptive or reconstructive president. But even midway through Obama's presidency, he still has the potential to be remembered as a reconstructive president and arguable has already achieved more 'change' than the Reagan presidency.

Finally, at the beginning of Obama's second term as president, he will have further opportunities to enhance his reconstructive potential. This thesis will specifically look at immigration reform and gun reform as two potential ways Obama can further enhance what in 20 years' time will be a potent legacy. Overall, what will shine through in 20 or 100 years' time, from the Obama presidency, is the fact that, because of him, millions of African-Americans, Hispanics and other minorities now believe that they too have the same opportunity to be elected president. Irrespective of any other achievements of an Obama presidency, this in itself is hugely

\footnotetext{
${ }^{11}$ Stephen Skowronek, Presidential Leadership in Political Time: Reprise and Reappraisal, (USA: University of Kansas Press, 2011).
} 
reconstructive, transformative, and is more potent than anything Reagan and the other reconstructive presidents could have ever hoped to achieve. 


\section{Chapter One: Presidential leadership theory - an overview}

'Leadership: The art of getting someone else to do something you want done because he wants to do it. ${ }^{, 12}$

President Dwight D. Eisenhower

Throughout recorded history one enduring idea has existed: the idea of leadership. Leadership has been a topic of study both intellectually and practically for over 2000 years since the time of the ancient Greek and Chinese philosophers. ${ }^{13}$ Leadership theory has evolved and changed throughout history by both leaders and academics alike. Academic Jon Johansson states:

'Embodying the ideas of leadership have been individuals and groups who have attempted to apply the instruments of leadership to achieve certain purposes and goals, for both good and ill. Keeping pace with idea and person is place - the context in which leadership occurs is a crucial factor in influencing what is or not possible. $^{14}$

Johansson goes on to argue that the 'interaction between ideas, person and place is a dynamic one which cannot be easily predicted. ${ }^{15}$ Leadership is demonstrated throughout all classes of society. This chapter will explain the leadership theories of Richard Neustadt, James MacGregor Burns, and James David Barber. This chapter will also introduce a discussion on cycles of politics and analyse more specifically the Schlesinger's and Erwin Hargrove's unique cycle of politics.

\footnotetext{
${ }^{12}$ General Dwight Eisenhower, 'Leadership Quotes', 2008, www.motivatingquotes.com/leadership.htm, (4 April 2012).

${ }^{13}$ Jon Johansson, Two Titans: Muldoon, Lange and Leadership, (Wellington: Dunmore Publishing, 2005), p. 18.

${ }_{14}^{2}$ Ibid.

15 lbid.
} 


\section{Richard Neustadt and Presidential Power}

Richard Neustadt's publication, Presidential Power and the Modern Presidents is an important first step in attempting to analyse the power of the presidency. Neustadt strikes at the core of American society when he stated:

'In the United States we like to "rate" a President. We measure him as "weak" or "strong" and call what we are measuring his "leadership". We do not wait until the man is dead; we rate him from the moment he takes office. We are quite right to do so. His office has become the focal point of politics and policy in our political system. Our commentators and our politicians make a speciality of taking the man's measurements. ${ }^{16}$

Neustadt sums up one of the core principles of democracy. We all have the right to rate our leaders as either weak or strong and we have the opportunity to vote in or out our leaders. Academics Joel D. Aberbach and Bert A. Rockman argue,

'Neustadt sees the president as a key actor amid a multitude of strategic players within a very convoluted strategic game. The game sets some profound limits on the president's possibilities - the result of a complex constitutional scheme that divides power and puts a president's agenda at the mercy of others. ${ }^{, 17}$

Despite this, Neustadt argues that a president still has the opportunity to optimise his bargaining position and make use of the leverage points available to him. Political leadership is a craft, and the president has to be a skilled master in the craft of politics, adjusting, when necessary, to changes in the available tools of political persuasion. ${ }^{18}$

Neustadt focuses on three distinctive attributes that a president must possess to be successful: the president's formal powers and the power to persuade; their professional reputation and their public prestige. Neustadt argues:

\footnotetext{
${ }^{16}$ Richard E. Neustadt, Presidential Power and the Modern Presidents: The Politics of Leadership from Roosevelt to Reagan, p.3.

${ }^{17}$ Joel D. Aberbach and Bert A. Rockman, 'Hard Times for Presidential Leadership?', Presidential Studies Quarterly, Vol. 29, No 4, 1999, p.761.

${ }^{18}$ lbid.
} 
'Effective influence for the man in the White House stems from three related sources: first are the bargaining advantages inherent in his job with which to persuade other men that what he wants of them is what their own responsibilities require them to do. Second are the expectations of those other men regarding his ability and will to use the various advantages they think he has. Third are those men's estimates of how his public views him and of how their publics may view them if they do what he wants. In short, his power is the product of his vantage points in government, together with his reputation in the Washington community and his prestige outside. ${ }^{19}$

Neustadt believes that 'far from being a powerful office, the presidency is essentially an empty vessel - a glorified "clerkship"- that at any given moment takes the shape of the person who fills it. Whether it is filled ineptly or skilfully was, for him, the vital question. What marked successful modern presidents was their understanding that presidential power is the power to persuade and not command. ${ }^{20}$ Neustadt's view of the presidency is out of step and out of date. The role is not an 'empty vessel' or a 'glorified clerkship', but a sophisticated role which demands working 24 hours a day, 7 days a week to respond to events, not only in America, but around the world. The president not only shapes the direction of America, but also is a leader on the world stage.

The first attribute is the president's 'formal powers'. Despite a president's range of extraordinary powers, Neustadt is a realist in arguing that there are limits to those formal powers. Neustadt sites President Harry Truman as a president who was acutely aware of those limits to power and was even more aware that real presidential power was the power to persuade. Neustadt argues:

'Powers are no guarantee of power; clerkship is no guarantee of leadership. The president of the United States has an extraordinary range of formal power, of authority in statute law and in the Constitution... Formal powers have no bearing

\footnotetext{
${ }^{19}$ Richard E. Neustadt, Presidential Power and the Modern Presidents: The Politics of Leadership from Roosevelt to Reagan, p.150.

${ }^{20}$ Micheal Nelson, 'Neustadt's Presidential Power at 50', March 28 2010, www.chronicle.com/article/Neustadts-Presidential/64816/, (14 March 2012).
} 
on influence. It disappears the moment one takes Truman to imply that mere assertion of a formal power is really enough. ${ }^{, 21}$

'Long before he (Truman) came to talk of Eisenhower he had but his own experience in other words: "I sit here all day trying to persuade people to do the things they ought to have sense enough to do without my persuading them...

That's all the powers of the president amount to". 22

Neustadt goes onto accurately point out that that a president does not obtain results by just giving orders:

"Here is testimony that despite his "powers" he does not obtain results by giving orders - or not, at any rate, merely by giving orders. He also has extraordinary status, ex officio, according to the customs of our government and politics. Here is testimony that despite his status he does not get action without argument. Presidential power is the power to persuade. ${ }^{23}$

Neustadt was quoting President Harry Truman when declaring that presidential power is the power to persuade. The power to persuade is perhaps the most important aspect of the presidency under Neustadt's thesis. Neustadt accurately argues that the power of the United States government is vastly dispersed and the president cannot simply command and receive:

'It is much more complicated than that. Other levels of government have different constituencies and difference sources of power and interest. The president is one man and needs others to get things done. The president must bargain and persuade others that what he wants is in their best interest. ${ }^{, 24}$

Neustadt defines the power to persuade as,

'Persuasive power, thus defined, amounts to more than charm or reasoned argument. These have their uses for a President, but these are not the whole of his resources. For the individuals he would induce to do what he wants done on their own responsibility will need or fear some acts by him on his responsibility. If they share his authority, he has some share in theirs. Presidential powers may be inconclusive when a President commands, but always remain relevant as he

\footnotetext{
${ }^{21}$ Richard E. Neustadt, Presidential Power and the Modern Presidents: The Politics of Leadership from Roosevelt to Reagan, p.11.

${ }^{22}$ Ibid.

${ }^{23}$ Ibid, p.11.

${ }^{24}$ Leif Ellington, 'Presidential Power and the Modern Presidents: A Review', www.academic.regis.edu/iriley/414\%20Power\%20to\%20Persuade.htm, (14 March 2012).
} 
persuades. The status and authority inherent in his office reinforce his logic and his charm. Status adds something to persuasiveness; authority adds still more. ${ }^{25}$

The power to persuade is critical to a president's overall success. If a president is unable to persuade the American people to support his programme then will unlikely get the support of congress. Before that, if a presidential candidate is unable to persuade the American people to support them, then they won't even be given the opportunity to roll out a legislative programme and a vision for America.

The second of the three distinctive attributes that a president must possess is professional reputation. Neustadt defines professional reputation as being:

'What other men expect of him becomes a cardinal factor in the president's own power to persuade. When people in the government consider their relationships with him it does them little good to scan the Constitution or remind themselves that Presidents possess potential vantage points in excess of enumerated powers. They must anticipate, as best they can, his ability and will to make use of the bargaining advantages he has. Out of what others think of him emerge his opportunities for influence with them. If he would maximize his prospects for effectiveness, he must concern himself with what they think. ${ }^{26}$

For a president to achieve anything in Washington he must have the support of Congress and thus his professional reputation in Washington is also vital. As will be explained in more depth later in this thesis, Obama struggled throughout his first term to muster the support of congress to deliver on the policies he campaigned on before the 2008 election, especially healthcare reform.

The third distinctive attribute that a president must possess according to Neustadt is public prestige. Neustadt argued that the "presidents "public prestige," their "standing with the public outside Washington," influences the decisions of other government officials and nongovernmental elites, including members of Congress and the bureaucracy, state governors,

\footnotetext{
${ }^{25}$ Neustadt, Richard, Presidential Power and the modern Presidents: The Politics of Leadership from Roosevelt to Reagan, p.30.

${ }^{26}$ Ibid, p.52.
} 
military commanders, party politicians, journalists, and foreign

diplomats. ${ }^{27}$ Neustadt describes public prestige as being:

'Prestige, like reputation, is a subjective factor, a matter of judgement. It works on power just as reputation does through the mechanism of anticipated reactions. The same men, Washingtonians, do the judging. In the instance of prestige they anticipate reactions from the public. Most members of the Washington community depend upon outsiders to support them or their interests. The dependence may be as direct as votes, or it may be as indirect as passive toleration. What their publics may think of them becomes a factor, therefore, in deciding how to deal with the desires of a President. His prestige enters into that decision; their publics are part of his. Their view from inside Washington of how outsiders view him thus affects his influence with them. ${ }^{28}$

Alongside a president's use of formal powers, a president's public prestige is central to whether a president will ultimately be successful. Presidents are voted into office by the American people and his standing among the people is central to their election, their re-election and how successful the president's legislative programme will be. Finally, Neustadt succinctly argues that:
'A President, himself, affects the flow of power from these sources, though whether they flow freely or run dry he never will decide alone. He makes his personal impact by the things he says and does. Accordingly, his choices of what he should say and do, and how and when, are his means to conserve and tap the sources of his power. Alternatively, choices are the means by which he dissipates his power. The outcome, case by case, will often turn on whether he perceives his risk in power terms and takes account of what he sees before he makes his choice. A President is so uniquely situated and his power so bound up with the uniqueness of his place, that he can count on no one else to be perceptive for him. ${ }^{29}$

While Neustadt wrote the first edition of Presidential Power over fifty years ago, his work is still widely read and cited today. It is a central theory on the presidency.

\footnotetext{
${ }^{27}$ Joseph A. Pika and John Anthony Maltese, The Politics of the Presidency: Revised Seventh Edition, (Washington DC: CQ Press, 2010), p.92.

${ }^{28}$ Neustadt, Richard, 'Presidential Power and the modern Presidents: The Politics of Leadership from Roosevelt to Reagan', p.73.

${ }^{29}$ Richard E. Neustadt, Presidential Power and the Modern Presidents: The Politics of Leadership from Roosevelt to Reagan, p.150.
} 
However, one of the more common criticisms of Neustadt is articulated by Samuel Kernell who argued:

'Presidential Power was basically right about politics in the 1950s, had become much less useful by the 1970s, when presidents began to de-emphasise behindthe-scenes persuasion in favour of "going public"- that is regularly using television to go over the heads of Congress to the people. ${ }^{30}$

Kernell describes this strategy as more akin to force than bargaining. Kernell's point is very relevant as the introduction of the mass media has enabled presidents to be able to by-pass Congress and speak directly to the American people. Obama and Reagan used this tactic often during their time as president. For instance Reagan addressed the nation after the Challenger Disaster in 1986 and during the Iran-Contra affair. Obama used primetime addresses to announce to the world that September 11 mastermind Osama Bin Laden had been captured and killed. Obama would also use primetime television to sell his healthcare policy to the nation. Generally the use of primetime addresses by Obama has largely been defensive operations, especially when dealing with Congress over economic issues, healthcare, and whether to raise the debt ceiling.

Neustadt argues that a president's currency was their formal and informal power. Jon Johansson argues that 'each political deal a president struck depended on the relative power weightings at play between respective political actors. Neustadt argues that what influenced these calculations was a president's use of their formal powers, how they were perceived by other political actors - actors who had independent power to reject that they found counterfeit - and how they were regarded by voters: their political prestige. ${ }^{31}$ Neustadt's prism has been the most enduring presidential leadership theory over the past fifty years.

\footnotetext{
${ }^{30}$ Micheal Nelson, 'Neustadt's Presidential Power at 50', March 28 2010, www.chronicle.com/article/Neustadts-Presidential/64816/, (14 March 2012). ${ }^{31}$ Jon Johansson, 'Obama in Political Time: Presidential Leadership in the $21^{\text {st }}$ Century', Fulbright Speech
} 
Johansson also touches on Obama when analysing Neustadt's prism. In regards to Obama's year long fight to pass health care reform, Johansson argues that the year-long fight 'was a result of him not being feared by those other political actors able to frustrate his legislative design. Their bargaining strength and ability to thwart the president increased as his public prestige fell. ${ }^{32}$ Obama ultimately failed to succinctly explain and educate the American people what the health care reform sought to achieve and why they should support it. Because of this, the reform became bogged down in Congress and the longer the legislation languished in Congress, the more defensive Obama became. Ultimately, health care reform would pass through Congress with a vote along partisan lines, but Obama would be weakened by the experience. Opinion polls following the passing of the legislation had Americans against the bill, and the debate brought about the advent of the Tea Party. The Democratic Party would suffer a heavy defeat in the 2010 mid-term elections. The healthcare debate will be expanded on in later chapters of this thesis, but is used here, to illustrate how Neustadt's constructs interact.

While Stephen Skowronek's recurrent model of presidential authority will be analysed in depth in the following chapter, Skowronek also critiques Neustadt's theory as well. Skowronek argues that 'the notion of a prior age when presidents did not have to be leaders - an age when vital national interests were only sporadically at the fore and most presidents could rest content with mere clerkship - is nothing more than a conceit of modern times. ${ }^{33}$ According to Skowronek, the president who forms an enduring governing coalition has more in common with the founder of earlier coalitions than with other presidents of his own era.

'Want to understand FDR? Don't compare him to Truman or Eisenhower, urged Skowronek - instead, compare him to Andrew Jackson. Want to make sense of

\footnotetext{
${ }^{32}$ Ibid.

${ }^{33}$ Micheal Nelson, 'Neustadt's Presidential Power at 50', March 28 2010, www.chronicle.com/article/Neustadts-Presidential/64816/, (14 March 2012).
} 
Jimmy Carter? Look to Franklin Pierce, who like Carter served in a governing coalition's rapidly fragmenting final days. ${ }^{34}$

This is an important point that Skowronek makes. Neustadt's theory does not have the scope to accurately reach across political time to compare a president from one era to another. It is ahistorical, in other words, treating all presidents since FDR as qualitatively different form his predecessors.

\section{James MacGregor Burns: Transactional vs. Transformational Leadership}

James MacGregor Burns introduces an important distinction between two types of leaders. Burns introduces the theory of transformational and transactional leadership. Burns' theory is not focussed solely on presidential leadership, but can be applied to leadership in general. Burns argues that the relationship between most leaders and followers are transactional - 'leaders approach followers with an eye to exchanging one thing for another: jobs for votes, or subsidies for campaign contributions. Such transactions comprise the bulk of the relationships among leaders and followers, especially in groups, legislatures, and parties. ${ }^{35}$ Burns explains the concept further:

'Transactional leadership occurs when one person takes the initiative in making contact with others for the purpose of an exchange of valued things. That exchange could be economic or political or psychological in nature: a swap of goods or of one good for money; a trading of votes between candidate and citizen or between legislators; hospitality to another person in exchange for willingness to listen to one's troubles. Each party to the bargain is conscious of the power resources and attitudes of the other. Each person recognises the other as a person. Their purposes are related, at least to the extent that the purposes stand within the bargaining process and can be advanced by maintaining that process. ${ }^{36}$

Under this form of leadership, Burns argues that beyond the transaction the relationship between the two groups does not continue. 'The bargainers have no enduring purpose that holds them together; hence

\footnotetext{
${ }^{34} \mathrm{lbid}$.

35 James MacGregor Burns, Leadership, p.4.

${ }^{36} \mathrm{lbid}, \mathrm{p} .20$.
} 
they may go their separate ways. A leadership act took place, but it is not one that binds leaders and follower together in a mutual and continuing pursuit of a higher purpose.,37

The opposite of transactional leadership is transformational leadership. Burns argues that transformational leadership is more complex, but more potent. Burns explains that the 'transforming leader recognises and exploits an existing need in, or demand of, a potential follower. The result of transforming leadership is a relationship of mutual stimulation and elevation that converts followers into leaders and may convert leaders into moral agents. ${ }^{38}$ Burns expands on this definition by arguing that:

'Transforming leadership occurs when one or more persons engage with others in such a way that leaders and followers raise one another to higher levels of motivation and morality. Their purposes, which might have started out as separate but related, as in the case of transactional leadership, become fused. Power bases are linked not as counterweights but as mutual support for common purpose. Transforming leadership ultimately becomes moral in that it raises the level of human conduct and ethical aspiration of both leader and led, and thus it has a transforming effect on both. ${ }^{39}$

Perhaps the best example of a transformational leader is Mahatma Gandhi: 'Many view Gandhi as the greatest moral leader of the twentieth century as well as a brilliant tactician, and both these qualities flowed from his extraordinary political creativity. Gandhi sought to teach and transform people who in turn would join him in the collective, national struggle. ${ }^{40}$

The most common criticism of Burns' theory is that Burns argues that leaders are either transactional or transformational. Erwin Hargrove states,

'Burns may have failed to appreciate that a transformational politician cannot be an effective transforming leader without first having mastered and practiced

\footnotetext{
37 Ibid.

${ }^{38}$ lbid, p.4.

39 lbid, p.20.

40 James MacGregor Burns, Transforming Leadership, (New York: Grove Press, 2003), p.158.
} 
transactional politics. There is no corresponding requirement for the transactional politician. ${ }^{41}$

Hargrove uses the example of Lincoln when running for president, who practiced transactional politics by arguing to strengthen the Union by tolerating slavery in the South, but not extending it. Hargrove also argues that Lincoln was a transactional president when he freed the slaves in the South in the Emancipation Proclamation, without disturbing slavery in the five Border States that stayed in the Union. With the Gettysburg Address, Lincoln's cause took on a moral purpose, hence shifting towards transformational politics. ${ }^{42}$ Despite this, Hargrove is correct in stating that Lincoln never stopped practising transactional politics.

Overall, Skowronek's reconstructive presidents are, in reality similar to Burn's transformational leaders, but Skowronek's reconstructive presidents are an extension of Burn's. Skowronek's theory takes into account the use of transactional politics as a means to transform politics.

\section{James David Barber and the Presidential Character}

James David Barber's central thesis argues that the presidency is much more than an institution. Barber introduces another important construct in evaluating presidential leadership; namely, the character of the president and whether their personality helps or hinders their performance. Barber argues that when citizens vote for a presidential candidate, 'we make, in effect, a prediction. We choose from among the contenders the one we think would be the best president. ${ }^{43}$ The central aim of Barber's thesis is to help those citizens cut through the confusion to develop criteria for choosing a president. Barber believes that a person's character is central to their performance in office and has developed a model to describe a president's character. ${ }^{44}$ Barber's model describes four types of

\footnotetext{
${ }^{41}$ Erwin C. Hargrove, The President as Leader: Appealing to the Better Angels of our Nature, p.31.

${ }^{42}$ Ibid.

${ }^{43}$ James David Barber, The Presidential Character: Predicting Performance in the White House Fourth Edition, p.1.

${ }^{44}$ Ibid.
} 
presidential character. The first baseline in defining presidential type is activity-passivity. The question that Barber poses is how much energy does the man invest in the presidency? The second baseline in defining presidential character type is positive-negative effect toward one's activity. This is how he feels about what he does. Relatively speaking, does he seem to experience his political life as happy or sad, enjoyable or discouraging, positive or negative in its main effect? ${ }^{45}$

\section{Active-Positive Character}

Barber argues that an active-positive character is 'congruence, a consistency between being very active and the enjoyment of it, indicating a relatively high self-esteem and relative success in relating to the environment. $^{, 46}$

'The president will show an orientation toward productiveness as a value, and an ability to use his styles flexibly, adaptively, suiting the dance to his music. He sees himself as developing over time toward relatively well defined personal goals growing toward his image of himself as he might yet be. ${ }^{47}$

Barber raises a point of caution by warning that the president may fail to take account of the irrational in politics. Not everyone will agree with a president, and a president with an active-positive character will find it hard to understand why others disagree with him. ${ }^{48}$

Ultimately an active-positive president is one who 'appear(s) to have fun in the vigorous exercise of presidential power. They seek out and even create opportunities for action, rather than waiting for the action to come to them. ${ }^{49}$ According to Barber, Presidents Franklin Roosevelt, Harry Truman and John Kennedy are presidents who shone through as ActivePositive presidents.

\footnotetext{
${ }^{45}$ Ibid, p.8.

46 lbid, p.9.

47 lbid

48 lbid.

49 lbid, p.267.
} 


\section{Active-Negative Character}

Barber argues that a president with an active-negative character has a compulsive quality, as if the man were trying to make up for something or to escape from anxiety into hard work. The president tends to have an aggressive stance towards the office he fills and is very ambitious, striving upwards to seek power. ${ }^{50}$

'Life is a hard struggle to achieve and hold power, hampered by the condemnations of a perfectionistic conscience. Active-negative types our energy into the political system, but it is an energy distorted from within. ${ }^{.51}$

Ultimately a president with an active-negative character 'displays a high expenditure of energy on political tasks and a continual, recurrent, negative emotional reaction to that work. His attention keeps returning to himself, his problems, how he is doing, as if he is always watching himself. ${ }^{, 52}$ Barber places Presidents Woodrow Wilson, Herbert Hoover and Lyndon Johnson as Active-Negative Presidents. ${ }^{53}$

\section{Passive-Positive Character}

A president possessing a passive-positive character is someone 'whose life is a search for affection as a reward for being agreeable and cooperative rather than personally assertive. ${ }^{54}$ Barber argues that these presidents, possess a contradiction between 'low-self-esteem (on the grounds of being unlovable, and unattractive) and a superficial optimism. A hopeful attitude helps dispel doubt and elicits encouragement from others. ${ }^{, 55}$ Passive-positive types often help, 'soften the harsh edges of politics. But their dependence and the fragility of their hopes and enjoyment make disappointment in politics likely. ${ }^{, 56}$ Barber believes that positive-passive presidents are political lovers. Like the passive-negative

\footnotetext{
${ }^{50}$ lbid, p.9.

${ }^{51}$ lbid.

52 lbid, p.81.

${ }^{53} \mathrm{lbid}$, p.48.

${ }^{54}$ Ibid, p. 10.

${ }^{55} \mathrm{lbid}$, p. 10.

${ }^{56}$ lbid, p.92.
} 
character that will be explained below, they are responders, not initiators or pushers, but they go about their work with a different demeanor and have an appearance of affectionate, hopefulness. They accentuate the positive. They boost. They sympathise. A passive-positive president is in many respects the nice guys of politics who finish first, only to discover that not everyone is a nice guy. ${ }^{57}$ Barber places Presidents William Howard Taft and Warren Harding as Passive-Positive Presidents. ${ }^{58}$

\section{Passive-Negative Character}

A passive-negative president's character is centered towards an orientation of doing a 'dutiful service, which compensates for low-selfesteem based on a sense of uselessness. ${ }^{, 59}$ Barber argues that passivenegative types are in politics because they think they ought to be.

'They may be well adapted to certain nonpolitical roles, but they lack the experience and flexibility to perform effectively as political leaders. ${ }^{60}$

Their tendency is to withdraw, to escape from the conflict and uncertainty of politics by emphasising vague principals and procedural arrangements. ${ }^{61}$ Barber argues that President Calvin Coolidge as the clearest twentieth century example of a Passive-Negative president. ${ }^{62}$ Overall Barber succinctly argues that active-positive presidents want to achieve results. Active-negatives aim to get and keep power. Passivepositives are after love and passive-negatives emphasise their civic virtues. $^{63}$

While the character of a president cannot be discounted, it is important to remember that there are other factors that need to be included when evaluating the success of a president. Skowronek argues:

\footnotetext{
57 Ibid, p. 195.

58 lbid.

59 lbid, p. 10.

60 lbid.

61 Ibid.

62 lbid, p.170.

63 lbid, p.1.
} 
'It takes a person of rare character to give those manipulations constructive purpose and national resonance. The problem is that this picture presents a rather one-sided interaction between the president and the political system. It is highly sensitive to difference among individual incumbents, but it tends to obscure differences in the political situations in which they act. If presidential leadership is indeed something of a struggle between the individual and the system, it must be recognised that the system changes as well as the incumbent. ${ }^{, 64}$

Skowronek is correct in asserting that the system that a president inherits changes as well as the character of the president. As will be explained in Chapter 2, Skowronek analyses not only how resilient or vulnerable a regime is, but also whether the president is opposed or affiliated to the political regime in power. These factors are just as important as the character of the president.

\section{Cycles of Politics}

Several theorists have attempted to break up American political history into distinct cycles. Jon Johansson argues that, 'the idea of cycles, both large and small, has been an instinctive part of thinking and language since humans began recording their observations of the natural world around them. ${ }^{65}$ At the centre of human nature, we seek to explain and understand our surroundings and we draw on what has come before us, to help us understand patterns. ${ }^{66}$ The idea of a cycle forms the centre of knowledge and a basic definition in the Oxford English Dictionary of a cycle is:

'A period in which a certain series of events or phenomena is completed, usually as part of a repeating succession of similar periods. ${ }^{67}$

While chapter two of this thesis will explain and analyse in detail Skowronek's recurring structure of political authority and outline the reasons why Skowronek's theory forms the theoretical background of this

\footnotetext{
${ }^{64}$ Stephen Skowronek, Presidential Leadership in Political Time: Reprise and Reappraisal, p.77.

${ }^{65}$ Jon Johansson, The Politics of Possibility: Leadership in Changing Times, (Wellington: Dunmore publishing, 2009), p.27.

${ }^{66}$ Ibid.

${ }^{67}$ Lesley Brown (ed.), The New Shorter Oxford English Dictionary on Historical Principles, (Oxford:

Clarendon Press, 1993), p.581.
} 
thesis, it is important to provide an overview of the Schlesinger and Hargrove sequence of politics as both of these theorists attempt to analyse presidential leadership from a historical point of view.

\section{The Schlesingers}

American, Ralph Emerson delivered a lecture in 1841 at the Boston Masonic temple titled 'The Conservative'. Emerson asserts that:

'The two parties which divide the state, the party of Conservatism and that of Innovation are very old, and have disputed the possession of the world ever since it was made... Now one, now the other gets the day, and still the fight renews itself as if for the first time, under new names and hot personalities. Innovation presses ever forward; Conservatism holds ever back. We are reformers spring and summer, in autumn and winter we stand by the old; reformers in the morning, conservers at night. Innovation is the salient energy; Conservatism the pause on the last moment. ${ }^{, 68}$

Emerson formed this argument over 170 years ago and his idea is still evident today. Periods of expansion and new ideas in the political discourse are always replaced by periods of the status quo; periods of time when those new ideas are given the opportunity to cement themselves into the fabric of American society.

Arthur Schlesinger and his son Arthur Schlesinger Junior have drawn upon the lecture of Emerson to create their own theory. The Schlesingers developed a theory of cycles of political eras that is, 'logically coherent and amenable to prediction because the causes of the cyclic dialectic are inherent to the process itself. ${ }^{69}$ Schlesinger identified the prime mover in American political life as the alternation of periods of concern for the rights of the few and the periods responsive to the rights of the many. ${ }^{70}$ Table one below outlines Schlesinger's political eras.

\footnotetext{
${ }^{68}$ Arthur M. Schlesinger Jr., The Cycles of American History, p.23.

${ }^{69}$ Erwin C. Hargrove, The President as Leader: Appealing to the Better Angels of our Nature, , p.58.

${ }^{70}$ lbid.
} 


\begin{tabular}{|l|l|}
\hline Table 1: Political Eras & \\
\hline Liberal or progressive period & Conservative period \\
\hline$\underline{1901-1919}$ & $\underline{1920-1932}$ \\
$\begin{array}{l}\text { Theodore Roosevelt } \\
\text { William Howard Taft } \\
\text { Woodrow Wilson }\end{array}$ & $\begin{array}{l}\text { Warren Harding } \\
\text { Calvin Coolidge } \\
\text { Herbert Hoover }\end{array}$ \\
\hline$\underline{193-1947}$ & \\
$\begin{array}{l}\text { Franklin Roosevelt } \\
\text { Harry Truman }\end{array}$ & \\
\hline
\end{tabular}

Source: Hargrove, 1998, p.59.

Schlesinger regarded the New Deal as ending in 1947 after the Republicans captured both houses of Congress in the 1946 elections. The average length of each period in both the nineteenth and twentieth centuries is approximately 16 years. Schlesinger would predict that the conservative period that began in 1947 would last until approximately 1962 and the next conservative period would begin around 1978.

Schlesinger's predictions were not too far from the mark with Kennedy winning the presidency in 1960 and Reagan in $1980 .{ }^{71}$ Schlesinger Jr. updated his father's original theory in 1986 and argued that Regan's conservative era, which began in 1980, would continue through to the 1990's when the next liberal era would begin. Clinton's election in 1992 brought about the next progressive era in American politics. ${ }^{72}$ Schlesinger argued that his cycle of politics is progressive and non-deterministic because he did not believe that the cycle would return to the same point, it was, rather, like a spiral. His cycle would see new conceptions of liberalism and conservatism evolve as new problems emerge. ${ }^{73}$

Schlesinger goes onto argue that conservative governments fail to solve new problems that occur and thus are succeeded by liberal administrations, which eventually burn out. ${ }^{74}$ Schlesinger makes a valid point, that even though broad cycles exist in politics, the ideas and theories do not return to the same point, as new pressures; both domestic and foreign, bring about policy advancement.

\footnotetext{
${ }^{71}$ lbid, p.59.

72 lbid, p.60

${ }^{73} \mathrm{lbid}$, p.59.

74 lbid.
} 
Leadership scholar Erwin C. Hargrove argues that a true cycle is selfgenerating and cannot be caused by external events. ${ }^{75}$ Schlesinger argues that reversals between the progressive or liberal era and the conservative era are not inevitable and they have to be set in motion by leaders. Schlesinger Jr. breaks with his father's argument by arguing that political generations do exist and are created by formative historical events, such as depression and war. ${ }^{76}$ This is an interesting claim that is backed by an argument which posits,

'The young progressives brought us the New Deal. And the youth of the New Deal created the Great Society. The students of the 1960's now staff the Clinton administration. The young conservatives of the 1950s served in the Nixon administration of the 1970's, and so on. ${ }^{77}$

More recently the young conservatives of the 1980s Reagan revolution served in President George W. Bush's administration and those who served with President Clinton have returned to serve in the current Obama administration. Presidents become the heroes of political generations and articulate their values, and this phenomenon is constantly repeated. ${ }^{78}$ Hargrove argues that Schlesinger's schema is 'a bit too neat, with a new generation coming to power every thirty years. ${ }^{, 79}$

\section{Hargrove's sequence of politics}

Erwin Hargrove argues that American political history is best analysed through a basic cycle of politics. Hargrove extends the Schlesinger theory, as he sees political cycles more nuanced than the more simple movement between liberal and conservative eras:

'Presidents elected to achieve a pause in government ultimately fail to address new problems, and opponents with the presidency. Those presidents carry out

\footnotetext{
${ }^{75}$ Ibid, p.60.

${ }^{76}$ lbid.

77 lbid.

78 lbid.

${ }^{79}$ lbid, p.61.
} 
reform programs as a result of their election, but the programs inevitably meet with opposition and a call for stability and a period of consolidation. ${ }^{, 80}$

Table 2 below outlines Hargrove's sequence of politics in America during the twentieth century.

\begin{tabular}{|l|l|l|}
\hline \multicolumn{2}{|l|}{ Table 2: Hargrove's sequence of politics } \\
\hline Preparation & $\underline{\text { Achievement }}$ & $\underline{\text { Consolidation }}$ \\
\hline Theodore Roosevelt & Woodrow Wilson & Warren Harding \\
\hline William Howard Taft & & Calvin Coolidge \\
\hline & & Herbert Hoover \\
\hline & Franklin Roosevelt & \\
\hline & Harry Truman & Dwight Eisenhower \\
\hline John Kennedy & Lyndon Johnson & Richard Nixon \\
\hline & & Gerald Ford \\
\hline Jimmy Carter & Ronald Reagan & George Bush \\
\hline Bill Clinton & & \\
\hline
\end{tabular}

Source: Hargrove, 1998, p.62.

Hargrove argues that periods of achievement are followed by periods of consolidation where those achievements are bedded in. Before periods of achievement, periods of preparation occur. As stated, humans like to explain the unexplained and cycles are a perfect way to predict what might come next. Schlesinger and Hargrove have done exactly this with their distinct versions of the American political cycle. Ultimately, Skowronek's classification system has been chosen to compare and contrast President Reagan and President Obama because of its simplicity. The four distinct categories that will be discussed presently create clear and distinct groupings. While I will address criticisms of Skowronek, his classification system is applicable to presidents across political time; hence it is a historical approach. Skowronek argues that Neustadt's classification introduced 'a sense of coherence into the relentless succession of incumbents and raised the study of leadership

${ }^{80}$ Ibid. 
efforts above the idiosyncrasies of the case at hand. ${ }^{81}$ Finally, it is important to note that no classification system is perfect and no classification system is free of difficult and/or controversial cases. ${ }^{82}$

${ }^{81}$ Stephen Skowronek, The Politics Presidents Make: Leadership from John Adams to Bill Clinton, p.5.

82 Philip Abbott, 'Borges's Encyclopaedia and Classification in Presidential Studies', Presidential Studies Quarterly, p.722. 


\section{Chapter Two: The Politics Presidents Make - Skowronek} Defined

Presidential leadership scholars over time have attempted to arrange presidents into distinct groupings, according to their preferred concepts underpinning presidential leadership. Professor Stephen Skowronek's organisation of the president bound in political time was outlined in his 1993 landmark publication The Politics Presidents Make. Skowronek's arrangement has been widely acclaimed by academics. One, Douglas J Hoekstra, explains that Skowronek's approach:

'Sweeps across the entirety of the presidency and it rests on an epistemology of historical pattern to locate (or to impose) the critical links of political circumstance and presidential action, which comprise the heart of his cyclical theory; and at the heart of presidential power, Skowronek finds not only the usual hard-headed deployment of power resources but also gifts historical and even literary in nature: "authority holds priority in determining the politics of leadership" and crucial to such authority is a president fully engaged in the arts of constructing and sustaining a "narrative" relating the presidents intentions to his historical place. ${ }^{, 83}$

Skowronek argues that to understand presidential leadership, one must see how it emerges from the cyclical roles particular presidents occupy. Successive incumbents each wrestle with new challenges that result from the actions of their immediate predecessors because 'presidents disrupt systems, reshape political landscapes and pass to successor's leadership challenges that are different from the ones just faced. ${ }^{84}$

Before analysing Skowronek's recurrent structures of presidential authority as outlined in table three below, explanation must be given to what Skowronek refers to as political time. Skowronek argues that presidential leadership follows a relatively regular but rather long cycle that he refers to as "political time". Skowronek sees political time as a function of increasing and decreasing opportunities to lead. Leadership

\footnotetext{
${ }^{83}$ Douglas J. Hoekstra, 'The Politics of Politics: Skowronek and Presidential Research', Presidential Studies Quarterly, Vol. 39, No. 2, 1999, pp.659-671.

${ }^{84}$ Stephen Skowronek, The Politics Presidents Make: Leadership from John Adams to Bill Clinton, p.6.
} 
becomes entropic within each political cycle.$^{85}$ Skowronek identifies a broad sequence in American politics and explains that, as regimes age, 'Tenacious in decay, political regimes are driven by their own affiliates toward flash points where the leader, struggling under the burdens of a vulnerable set of commitments, finally loses all effective warrants for action and unwittingly makes himself the foil for a wrenching reconstruction. ${ }^{86}$

\begin{tabular}{|c|c|c|}
\hline \multicolumn{2}{|c|}{ Table 3: Recurrent Structures of Presidential Authority } \\
\hline $\begin{array}{c}\text { Previously } \\
\text { established } \\
\text { commitments }\end{array}$ & \multicolumn{2}{|c|}{ President's Political identity } \\
\hline$\underline{\text { Vulnerable }}$ & $\begin{array}{c}\text { Opposed } \\
\text { Politics of } \\
\text { Reconstruction } \\
\text { Resilient }\end{array}$ & Politics of disjunction \\
\hline & Politics of preemption & Politics or articulation \\
\hline
\end{tabular}

Skowronek's theory is best analysed through this prism and, looking back at American political history, he argues that a recurrent sequence of change is evident: 'Political breakthroughs, followed by political breakups, followed by political breakdowns - and it identifies typical reconfigurations of the relationship between the presidency and the political system along the way. ${ }^{87}$ Great leaders come to power in an abrupt break from a long established political order, and each led an infusion of new political interests into control of the government. Second, after the initial break with the past and the consolidation of a new system of governmental control, a general decline in the effectiveness of regime insiders is notable. ${ }^{88}$ Skowronek's prism is well suited when comparing two presidents as there

\footnotetext{
${ }^{85}$ Joel D. Aberbach and Bert A. Rockman, 'Hard Times for Presidential Leadership?' Presidential Studies Quarterly, Vol. 29, No 4, 1999, pp.758-759.

${ }^{86}$ Stephen Skowronek, The Politics Presidents Make: Leadership from John Adams to Bill Clinton, p.51.

87 Joel D. Aberbach and Bert A. Rockman, 'Hard Times for Presidential Leadership?', p.728.

${ }^{88}$ Stephen Skowronek, Presidential Leadership in Political Time: Reprise and Reappraisal, p.30.
} 
is a recurrent sequence of change that exists in American politics that seemingly embraces both Reagan and Obama.

In table three above, Skowronek uses several key terms that will be employed throughout this thesis. The first of Skowronek's variables asks whether the previous regime's previously established commitments are vulnerable or resilient. Skowronek believes that leadership opportunities hinge on whether the governing commitments embodied in previously established institutional arrangements are resilient or vulnerable. ${ }^{89}$ Skowronek poses several questions when analysing whether or not the established regime is vulnerable or resilient:

- 'Do those commitments claim formidable political, organisational, and ideological support?

- Do they offer credible solutions or guides to solutions to the problems of the day?

- Or have they in the course of events become open to attack as failed and irrelevant responses to the nation's problems? ${ }^{90}$

These questions strike at the heart of Skowronek's theory. The answer to these questions will help decide whether the established regime is either vulnerable or resilient. The more resilient received commitments are, the more authoritative the affiliated leader will be in their determination to continue or complete the work, and the more problematic the determination of the opposition leaders to reverse course and challenge the basic governing arrangement. On the other hand, the more vulnerable the received commitments are, the more authority the opposition leader possess in his determination to displace the basic governing arrangements, and the more problematic the determination of the affiliated to continue. ${ }^{91}$

${ }^{89}$ Stephen Skowronek, The Politics Presidents Make: Leadership from John Adams to Bill Clinton, p.36.

${ }_{90}$ lbid.

${ }^{91}$ lbid. 
The second of Skowronek's variables is concerned with whether a president's political identity is either opposed or affiliated to the preestablished regime. Leaders are elected to power either affiliated or opposed to the pre-established regime and because of this there are two generic projects for political action:

'The leadership project of the opposition leader is to challenge the received agenda, perhaps to displace it completely with another; the leadership project of the affiliated leader is to continue, perhaps to complete, the work on that agenda. $^{92}$

Skowronek argues that an affiliated leader is beholden to received arrangements in a way that the opposition leader is not, he has more difficulty maintaining warrants for the choices he makes and the priorities and promises he sets himself. On the other hand, an opposition leader comes to power with independence from those established commitments and can more readily justify the disruptions and changes he makes. ${ }^{93}$ Skowronek's prism is a step forward from those advocated by the Schlesingers and Hargrove as it is more focussed on the system a president inherits and whether the pre-established regime is resilient or vulnerable to change.

Skowronek argues that presidential leadership is framed as a contest to determine whether the incumbent has 'the stuff' to make the system work. Timeless forces of political fragmentation and institutional intransigence threaten to frustrate the would-be leader at every turn. Success is reserved for the exceptional individual. It takes a person of rare political skill to control this system and manipulate the government in politically effective ways. It takes a person of rare character to give those manipulations constructive purpose and national resonance. ${ }^{94}$ Politics today is seen more as a contest of personality rather than a contest of ideas. This in itself will make it harder for the individual to 'manipulate' the

\footnotetext{
${ }^{92}$ Ibid, p.35.

93 Ibid.

${ }^{94}$ Stephen Skowronek, Presidential Leadership in Political Time: Reprise and Reappraisal, p.76
} 
system and give those manipulations purpose and national resonance. ${ }^{95}$ For example the primary system today is more about personality and money, rather than policy. ${ }^{96}$

Before focussing on the four recurrent structures of presidential authority, Skowronek divides American presidential history into four distinct eras. The first era is the Patrician Era (1789-1832) where the characteristic presidential resource was personal reputation among other notables and the typical presidential strategy was to stand as national tribune above faction and interest. The second era is the Partisan Era (1832-1900), where party organisation and executive patronage were characteristic presidential resources and the typical presidential strategy consisted of manipulating the distribution of executive patronage to party factions and local machines as the broker for the national coalition. The third era was the Pluralist Era (1900-1972), where expanding executive establishment attended to newly nationalised interests and America's rise to world power were characteristic presidential resources; typical presidential strategy consisted of bargaining with leaders of all institutions and organised interests as the steward of national policy-making. The current mode of governmental operations that Skowronek argues America is operating under is the Plebiscitary Era (1972-present). The characteristic presidential resource is an independent political apparatus and mass communication technologies and the typical presidential strategy consists of appealing for political support over the heads of Washington elites directly to the people at large. ${ }^{97}$

\section{The Politics of Reconstruction}

As shown in table three, Skowronek places presidents into four distinct groupings, the first of which is the politics of reconstruction. These presidents herald from the opposition to the previously established

\footnotetext{
95 Ibid.

${ }^{96}$ Ibid,81.

97 Stephen Skowronek, The Politics Presidents Make: Leadership from John Adams to Bill Clinton, lbid, p.53.
} 
regime, and pre-established commitments of ideology and interest have, in the course of events, become vulnerable to direct repudiation as failed or irrelevant responses to the problems of the day. ${ }^{98} \mathrm{~A}$ reconstructive president appears after a disjunctive president and reveals that the old order is incapable of governing any longer, and a new order, which promises to overturn the old order's commitments, takes power. These presidents have wide-ranging freedom to establish a new order, make new commitments and exercise considerable power. ${ }^{99}$ Skowronek labels that Thomas Jefferson, Andrew Jackson, Abraham Lincoln, Franklin Roosevelt and, to a lesser extent, Ronald Reagan as the great repudiators who led during a politics of reconstruction.

\section{Thomas Jefferson Reconstruction}

Thomas Jefferson served as the third president of the United States from 1801-1809 and was described by Skowronek as the first of the reconstructive presidents. In the 1800 presidential election, Alexander Hamilton, the father of the Federalist Party, opted to become the spoiler between Federalist President John Adams and Thomas Jefferson. Hamilton was disillusioned with the leadership of Adams and believed the best way to rebuild the Federalist Party was from the opposition. ${ }^{100}$ Hamilton argued:

'If we must have an enemy at the head of the government, let it be one whom we can oppose, and for whom we are not responsible, who will not involve our party in the disgrace of his foolish and bad measures. Under Adams, as under Jefferson, the government shall sink. The party in the hands of whose chief it shall sink will sink with it - and the advantage will all be on the side of his adversaries. ${ }^{101}$

Jefferson heralded from the opposition. He was elected as President in 1800 and was in a unique position to reconstruct American society and

\footnotetext{
${ }^{98} \mathrm{Ibid}$, p.36.

${ }^{99}$ Aaron Manners, Reviewing Presidential Leadership in Political Time, December 62010 , www.veepcritique.blogspot.com/2010/12/reviewing-presdiential-ladership-in.html, (1 October 2011). ${ }^{100}$ Stephen Skowronek, The Politics Presidents Make: Leadership from John Adams to Bill Clinton, lbid, p.62.

${ }_{101}$ Alexander Hamilton, The Works of Alexander Hamilton, Vol. 10, ed. Henry Cabot Lodge (New York: Putnum, 1904), p.375.
} 
government after the retirement of George Washington and twelve years of Federalist control.

Skowronek argues that Hamilton failed to take into account the backlash against the Federalists because of the rupture and disgrace of their party that had, for twelve years, defined America. ${ }^{102}$ Jefferson came to power and made good to 'sink federalism into an abyss, from, which there could be no resurrection'. ${ }^{103}$ Jefferson would go onto win re-election in 1804 and reconstruct the terms and conditions of legitimate national government. He was one of the few presidents so situated in political time as to be able to manipulate the order-shattering, order-affirming, and order-creating components of presidential action in a consistent and mutually reinforcing way. $^{104}$

Thomas Jefferson was one of the most significant presidents in history whose major achievements included the purchase of the Louisiana Territory in 1803, which doubled the size of the United States. During his second term, Jefferson encountered difficulties on both the domestic and foreign fronts. Despite this, Jefferson is most remembered for his efforts to maintain neutrality in the midst of the conflict between Britain and France. ${ }^{105}$ Jefferson would establish the right of an incoming president to discharge the major political appointees of his predecessor, but was restrained by Chief Justice John Marshall from applying the same principle to federal judges. ${ }^{106}$ This practice continues to this very day. Jefferson would become the first leader of an opposition political movement to wrest control of the national government from the party in power. Jefferson proved not only to the nation, but to the entire world the

\footnotetext{
${ }^{102}$ Stephen Skowronek, The Politics Presidents Make: Leadership from John Adams to Bill Clinton, p.62.

${ }^{103}$ Thomas Jefferson, The Works of Thomas Jefferson, Vol. 9, ed. Paul L. Ford (New York: Putnum, 1955), p.401.

${ }^{104}$ Stephen Skowronek, The Politics Presidents Make: Leadership from John Adams to Bill Clinton, p.63.

${ }^{105}$ Monticello, 'Brief Biography of Thomas Jefferson', http://www.monticello.org/site/jefferson/briefbiography-thomas-jefferson, (1 January 2012).

${ }_{106}$ David C. Whitney, The American Presidents: Biographies of the Chief Executives from George Washington through Barack Obama, (USA: Direct Brands Inc., 2009), p.29.
} 
emerging strength and staying power of the American republic and its democratic system under a changing political philosophy. ${ }^{107}$

\section{Andrew Jackson Reconstruction}

In the 1824 election, Jackson received the biggest share of the popular vote as well as the most electoral votes. While Jackson was the leading candidate he did not achieve a clear majority and the House of Representatives was called on to decide the election. John Quincy Adams would gain the support of Henry Clay's supporters and thus Adams was voted in as president. The election of 1824 and the chaos that would ensue would be the beginning of the end for the old political system. ${ }^{108}$ It would take another four years before Jackson would be elected president. Skowronek argued that the Jacksonian movement carried a disparate coalition of discontents into the election of 1828. This coalition consisted of Southern Planters who were hostile to high tariffs, Northern Radicals, Western debtors and Old Republicans. Jackson would go on to win 178 electoral votes compared to 83 for John Quincy Adams, the incumbent president. It was a sweeping victory for the opposition who routed the National Republicans from control of all the political branches of the federal government: ${ }^{109}$ 'For the first time in almost 30 years, a president's impulse to fashion his place in history was released from the burdens of upholding the integrity of past commitments. ${ }^{110}$

Within eight years, President Jackson melded a coalition of personal followers who had elected him into the country's most durable and successful political party, an electoral machine whose organisation and discipline would serve as a model for all others. At the same time, his controversial conduct in office galvanised his opponents to organise the Whig party. The Democratic Party was Jackson's child and the national two-party system was his legacy. Jackson would also challenge, and then

\footnotetext{
107 Ibid, p.29.

108 lbid, p.63.

${ }^{109}$ Stephen Skowronek, The Politics Presidents Make: Leadership from John Adams to Bill Clinton, p.130.

${ }_{110} \mathrm{Ibid}, \mathrm{p} .131$.
} 
change the nature of the United States banking system and through it, the economy. ${ }^{111}$ Jackson's ascent to power would create a new party system that endures to this very day. Jackson's reconstruction was unique as it, according to Skowronek: 'transformed the operating mores of American government as dramatically as it altered basic governmental commitments. It not only reversed the ideological thrust of the national government and redirected its substantive uses, it also extricated the presidency from suffocating doctrines of legislative supremacy, rebuilt the political foundations of the executive office, recast the operations of the bureaucracy, and ushered in a nationally competitive party politics. ${ }^{, 112}$

\section{Abraham Lincoln Reconstruction}

When Abraham Lincoln was elected president in the 1860 election, America stood at a crossroad. Lincoln led America though a great constitutional, military and moral crisis - the American Civil War. By the time Lincoln delivered his first inaugural address on March 4, 1861, much of the South had already seceded from the Union and created their own Government with Jefferson Davis named provisional president. On April 12, 1861, with the Confederates attack on Fort Sumter signalled the beginning of the Civil War. The War would rage for four years and would result in the bloodiest years in United States history. In the second year of the War, Lincoln would issue the Emancipation Proclamation, freeing all slaves in the Confederate states. Eleven months later, Lincoln delivered his most famous speech, the Gettysburg Address, on the site where over 50,000 men had lost their lives in the war's deadliest battle. ${ }^{113}$

'Four score and seven years ago our fathers brought forth on this continent, a new nation, conceived in Liberty, and dedicated to the proposition that all men are created equal.

\footnotetext{
${ }^{111}$ Miller Centre, 'Andrew Jackson: Impact and Legacy', http://millercenter.org/president/jackson/essays/biography/9 (13 January 2012).

${ }^{112}$ Stephen Skowronek, The Politics Presidents Make: Leadership from John Adams to Bill Clinton, p.133.

${ }_{113}$ National Museum of American History, 'Abraham Lincoln', http://americanhistory.si.edu/presidency/timeline/pres era/3 677.html, (27 February 2013).
} 
Now we are engaged in a great civil war, testing whether that nation or any nation so conceived and so dedicated, can long endure. We are met on a great battlefield of that war. We have come to dedicate a portion of that field, as a final resting place for those who here gave their lives that that nation might live. It is altogether fitting and proper that we should do this.

But, in a larger sense, we cannot dedicate -- we cannot consecrate -- we cannot hallow -- this ground. The brave men, living and dead, who struggled here, have consecrated it, far above our poor power to add or detract. The world will little note, nor long remember what we say here, but it can never forget what they did here. It is for us the living, rather, to be dedicated here to the unfinished work which they who fought here have thus far so nobly advanced. It is rather for us to be here dedicated to the great task remaining before us -- that from these honoured dead we take increased devotion to that cause for which they gave the last full measure of devotion -- that we here highly resolve that these dead shall not have died in vain -- that this nation, under God, shall have a new birth of freedom -- and that government of the people, by the people, for the people, shall not perish from the earth. ${ }^{114}$

Lincoln's Emancipation Proclamation ordering freedom for slaves in the rebelling states crystallised the central issue of the War and moved the nation a great step forward toward realising Jefferson's dream of equality for all men. ${ }^{115}$

Lincoln was successful in preserving the Union and ending slavery in America. Skowronek argues that 'Lincoln's reconstruction was the most disruptive and penetrating to date, but in recasting basic commitments of ideology and interest he had to grapple with the suborn persistence of the organisational forms and institutional operations of the nineteenth-century party governance, and this delimited his control over the process. ${ }^{116}$ Lincoln would win re-election in 1864 by winning 212 electoral votes compared 21 for George B McClellan. Lincoln would speak on the theme of reconciliation during his second inaugural address:

\footnotetext{
${ }^{114}$ Abraham Lincoln, 'Gettysburg Address', in Abraham Lincoln Online: Speeches and Writings, http://www.abrahamlincolnonline.org/lincoln/speeches/gettysburg.htm, (27 February 2013).

${ }^{115}$ David C. Whitney, The American Presidents: Biographies of the Chief Executives from George Washington through Barack Obama, p.135.

${ }^{116}$ Stephen Skowronek, The Politics Presidents Make: Leadership from John Adams to Bill Clinton, p.197.
} 
'With malice toward none, with charity for all, with firmness in the right as God gives us to see the right, let us strive on to finish the work we are in, to bind up the nation's wounds, to care for him who shall have borne the battle and for his widow and his orphan, to do all which may achieve and cherish a just and lasting peace among ourselves and with all nations. ${ }^{117}$

While Lincoln would ultimately be successful in preserving the Union he would not be successful in completing his second term. Lincoln would be fatally shot at Ford's Theatre by southern sympathiser John Wilkes Booth on April 15, 1865. The assassination would occur just days after the Confederate Army formally surrendered at Appomattox court house in Virginia on April 9. Lincoln was 'an awesome figure of a statesman who would secure a break with the past more fundamental than any since the American Revolution itself. ${ }^{118}$

\section{FDR Reconstruction}

Franklin Delano Roosevelt (FDR) was elected president in 1932 in the midst of the Great Depression. FDR would win the 1932 election in a landslide, by winning 472 electoral votes and $57.4 \%$ of the popular vote. FDR argued that he was the candidate with "clean hands" at a moment when failed policies, broken promises, and embarrassed clients were indicting a long-established political order. ${ }^{119}$ In analysing FDR, there is nothing more basic to the reconstructive stance than his assertion that he was the candidate with clean hands. FDR was also different to previous reconstructive presidents in that Jackson was a party unto himself and Lincoln was a candidate in a new party. ${ }^{120}$

\footnotetext{
${ }^{117}$ Abraham Lincoln, 'Inaugural Address March 4, 1865', in My Fellow Americans: Presidential Inaugural Addresses from George Washington to Barack Obama, (Florida: Red and Black Publishers, 2009), p.150.

${ }^{218}$ Stephen Skowronek, The Politics Presidents Make: Leadership from John Adams to Bill Clinton, p.198.

${ }_{119}$ Franklin D. Roosevelt, 'Acceptance Speech before the Democratic National Convention', Chicago, July 2 1932, The Public Papers and Addresses of Franklin D. Roosevelt, 13 Vols., ed. Samuel I. Rosenman (New York: Random House, 1938-1950), Vol. 1, p.649.

${ }_{120}$ Stephen Skowronek, The Politics Presidents Make: Leadership from John Adams to Bill Clinton, p.289.
} 
FDR's New Deal was a program of social justice and was more sweeping than anything that had ever been previously attempted. The New Deal would bring security to the aged, relief to the unemployed and shorter hours and higher wages to working men. FDR would remake the federal government, by adding new agencies and services. Within his own party, FDR would reform the Democratic Party to cast aside the long-standing commitment to states' rights and forcing acceptance of Alexander Hamilton's belief in a strong central government. ${ }^{121}$ Fred Greenstein argues that in the depths of the Great Depression, FDR restored faith in a political system that Americans had few reasons to respect. Following Pearl Harbour, FDR rallied the nation and its allies in an epic conflict in which victory was by no means assured. Both as an inspirational leader and as a master politician, FDR provided a benchmark for later presidents, including President Reagan and President Obama. ${ }^{122}$

Overall, American politics are transformed when new interests secure a firm grip on power, when institutional relationships are rearranged to support them, when governmental priorities are durably recast, and when a corresponding set of legitimating ideas becomes the new common sense. ${ }^{123}$ Reconstructive leaders have never been overly successful in solving the problems that brought them into office in the first place.

Skowronek argues that reconstructive leaders do not have to solve those problems; they do, however, close off the prior course of development. ${ }^{124}$ Reconstructive leaders are able to chart a new course of development, devoid of any similarities to the previous course. In other words they are able to create a new path.

\footnotetext{
${ }^{121}$ David C. Whitney, The American Presidents: Biographies of the Chief Executives from George Washington through Barack Obama, p.287.

${ }^{122}$ Fred I Greenstein, The Presidential Difference: Leadership Style from FDR to Barack Obama, (New Jersey: Princeton University Press, 2009), p.10.

${ }^{223}$ Stephen Skowronek, Presidential Leadership in Political Time: Reprise and Reappraisal, p.171. ${ }^{124}$ Stephen Skowronek, The Politics Presidents Make: Leadership from John Adams to Bill Clinton, p.428.
} 


\section{The Politics of Disjunction}

The second of the four options that Skowronek identifies, is the politics of disjunction. Take a step back from the greatness that awaits a president of reconstruction and you get the complete opposite situation. A disjunctive president is affiliated with a set of established commitments that have in the course of events been called into question as failed or irrelevant responses to the problems of the day. ${ }^{125}$ The disjunctive period occurs when a long-standing political order is no longer able or capable of addressing the challenges facing the nation. These leaders become caught between the demands of their supporters and their need to take actions their supporters oppose. Disjunctive presidents cannot satisfy the demands of their supporters, leaving them isolated and vulnerable to electoral defeat. ${ }^{126}$

Affiliation with a vulnerable regime might serve as a working definition of the impossible leadership situation. Open recognition of serious problems within the establishment coupled with a promise of continuity leave the incumbent little authority with which to sustain the inherently disruptive and highly politicising effects of presidential action. Initiatives that reach out to the existing coalition will be portrayed by opponents as the core of the nation's problems. If the president was to confront the issues at hand or appear to challenge the basic commitments of the established regime then the president could alienate the natural base of his support and become politically isolated. ${ }^{127}$ This is the most impossible form of leadership and Skowronek sees John Adams, John Quincy Adams, Franklin Pierce, James Buchanan, Herbert Hoover and Jimmy Carter as prime examples of presidents who are singled out as political incompetents and hence disjunctive presidents. ${ }^{128}$

\footnotetext{
125 lbid, p.39.

${ }^{126}$ Aaron Manners, 'Reviewing 'Presidential Leadership in Political Time', December 62010 , www.veepcritique.blogspot.com/2010/12/reviewing-presdiential-ladership-in.html, (1 October 2011). ${ }^{127}$ Stephen Skowronek, Presidential Leadership in Political Time: Reprise and Reappraisal, p.90. 128 Stephen Skowronek, The Politics Presidents Make: Leadership from John Adams to Bill Clinton, p.39.
} 
Before the Reconstruction of Andrew Jackson came the disjunctive presidency of John Quincy Adams. Adams was the son of the second president, John Adams and was the fourth consecutive Republican to come to the presidency. Adams' election came after the contested election of 1824. Skowronek argues that Adams personified the regime's crisis of identity. ${ }^{129}$ Adams was elected with limits to his power and Skowronek points to his inaugural address as when his leadership problem became clear. Adams tied his future prospects to two historic trends. He applauded the great progress the nation had made in overcoming the political divisions of the past, and he proposed to take the one last step necessary to realise the highest ideals of patrician governance: he would discard party labels altogether and run his administration solely on the basis of merit. ${ }^{130}$ By tying his presidency to what has come before, Adams was fully aware of his place in history and where he stood in political time.

Adams would call for a wide-ranging public improvement program to be financed by Congress. He asked Congress to establish a national university in Washington, to build an astronomical observatory, and to construct more roads and canals. Adams would find it difficult to bend to public popularity and with little support from Congress, was unable to achieve his program. ${ }^{131}$ Adams was an affiliated leader in a vulnerable regime and was thus lacking the authority to repudiate the past. Adams was tied to the past and in most respects embodied it and had no latitude to change the direction of the polity. Adams would only serve one term as president, before suffering a heavy electoral defeat to Andrew Jackson.

\footnotetext{
${ }^{129}$ Ibid, p.110.

${ }^{130}$ Ibid.

${ }^{131}$ David C. Whitney, The American Presidents: Biographies of the Chief Executives from George Washington through Barack Obama, p.64.
} 
Eight months after President Herbert Hoover took office in 1929, Wall Street crashed and signalled the beginning of the Great Depression. Hoover was known as the great innovator during the 1920s when he served as the United States Secretary of Commerce and when the Great Depression arrived, Hoover was active in attempting to find a solution to the problems of the day. When those solutions did not come to fruition, Hoover was defeated and attacked as being out of touch. ${ }^{132}$

Hoover launched new public work programs, hoping that the building industry could absorb the unemployed. He would pass a substantial reduction in income tax rates, hoping to stimulate the economy. Hoover would oppose direct federal relief to the unemployed, and his Republican Congress in February 1930 had to override his veto on the Bonus Act, giving almost a billion dollars to veterans. In the spring of 1932 thousands of World War I veterans marched on Washington, demanding further bonus payments. When Congress adjourned without giving the veterans what they asked, Hoover ordered the army to move the veterans on. ${ }^{133}$ This move would be highly controversial and would send shockwaves throughout America.

Skowronek argues that Hoover took charge of a political regime wracked by decades of sectarian controversy. Hoover crafted a leadership posture as delicate as it was ingenious; committed to innovation, it hovered innocuously over a regime bereft of political consensus. The collapse of Hoover's control over the political definition of his actions preceded the collapse of the economy. Hoover's initial leadership posture proved so delicate that it crumbled before the demands of his own supporters. ${ }^{134}$

\footnotetext{
${ }^{132}$ Stephen Skowronek, The Politics Presidents Make: Leadership from John Adams to Bill Clinton, p.261.

${ }^{133}$ David C. Whitney, The American Presidents: Biographies of the Chief Executives from George Washington through Barack Obama, p.283.

${ }^{134}$ Stephen Skowronek, The Politics Presidents Make: Leadership from John Adams to Bill Clinton, p.263.
} 
When Jimmy Carter was sworn in as president of the United States of America in January 1977, America had endured over a decade of pain. 1960s America was dominated by the assassination of John F Kennedy, the Civil Rights and the Vietnam War. Richard Nixon and the Watergate scandal gripped America during the early 1970s.

Jimmy Carter launched his presidency with an outburst of populist symbolism. But by the summer of 1980 Carter's approval ratings had descended to the lowest level in the history of presidential polling. ${ }^{135}$ During the Carter years, the economy was crippled by a combination of high inflation and economic stagnation. Carter's presidency also suffered from his own reluctance to engage in normal political give and take, which antagonised the members of the political community, whose support was needed to enact his program. ${ }^{136}$ Ultimately the Democratic Party tore itself apart in a revolt against Carter and the ideas he articulated. Carter would be challenged by Edward Kennedy for the Democratic Nomination in 1980 and it was evident at the Democratic convention that broad sections of the party rejected his message, discredited his efforts, and revealed to the nation that it had nothing more to offer. ${ }^{137}$ Carter was not part of the solution to the nation's problems and was roundly defeated in 1980 by Reagan.

\section{The Politics of Preemption}

The third period of politics that Skowronek has developed is the politics of preemption. These presidents operate as opposition leaders in a resilient regime. Skowronek argues that the politics of preemption is the most curious of all leadership situations: 'Like all opposition leaders, these presidents have the freedom of their independence from established

\footnotetext{
${ }^{135}$ Gallup Polling, 'Presidential Job Approval Centre', 2011, http://www.gallup.com/poll/124922/Presidential-Approval-Center.aspx (28 December 2011). ${ }^{136}$ Fred I Greenstein, The Presidential Difference: Leadership Style from FDR to Barack Obama, p.126.

${ }^{137}$ Stephen Skowronek, Presidential Leadership in Political Time: Reprise and Reappraisal, p.76.
} 
commitments, but unlike presidents in a politics of reconstruction, their repudiative authority is manifestly limited by the political, institutional, and ideological supports that the old establishment maintains. ${ }^{138}$ One way Skowronek describes a pre-emptive president is that while there is a dominant order linked to one party, occasionally the other party's nominee is elected president. These presidents usually distance themselves from the past failed order of their party and are therefore less boxed in by ideology and so readily adopt policies from the dominant order. On the other hand these presidents are frequently labelled dishonest or tricky by their opponents because of their ideological inconsistency. ${ }^{139}$ Skowronek argues that Andrew Johnson, Woodrow Wilson, Richard Nixon and Bill Clinton stand out for both their aggressive employment of the powers of their office and for their wrenching political impacts. ${ }^{140}$ Also of interest is that all of these presidents won the presidency in a three-way race that featured a major schism within the dominant party. ${ }^{141}$

\section{The political preemption of Richard Nixon}

Richard Nixon was elected in 1968 presidential election in a close result by defeating Vice-President Humphries in a three-way battle. While Nixon won re-election in 1972 in a landslide by motivating the "Great Silent Majority", he is most famously remembered for the Watergate scandal. Nixon would be the first president to resign from office to avoid impeachment and conviction by Congress for misuse and abuses of power.

Nixon's first term was marked by foreign policy achievements that brought improved relations with the Soviet Union and communist China and beginning the end of United States participation in the deeply unpopular

\footnotetext{
138 Stephen Skowronek, The Politics Presidents Make: Leadership from John Adams to Bill Clinton, p.43.

${ }^{139}$ Aaron Manners, Reviewing 'Presidential Leadership in Political Time, December 62010 , www.veepcritique.blogspot.com/2010/12/reviewing-presdiential-leadership-in.html, (1 October 2011 ). ${ }^{140}$ Stephen Skowronek, The Politics Presidents Make: Leadership from John Adams to Bill Clinton, p.44.

${ }^{141}$ Stephen Skowronek, Presidential Leadership in Political Time: Reprise and Reappraisal, p.107.
} 
Vietnam War. Throughout his presidency Nixon faced a politically hostile Congress and he would be the first president to twice win re-election while being unable to lead his party to a victory in either house of Congress. ${ }^{142}$ By the end of his first term, Nixon had extricated the United States from the Vietnam War and transformed his nation's relations with China and the Soviet Union. A year and a half into his second term, he was forced to resign from office after it became known that he had covered up his administration's complicity in the 1972 Watergate break-in, lying even to his supporters about having done so. ${ }^{143}$ Nixon was elected as an opposition leader to the resilient regime that was created under FDR.

The political preemption of Bill Clinton

After twelve years of Republican rule, the man from Hope, Arkansas, Bill Clinton, was elected president in 1992. The Clinton presidency was fraught with difficulties, and Clinton achieved far less than might have been expected of a chief executive with towering political skills and policy aspirations. ${ }^{144}$ Clinton would suffer many setbacks during his eight year presidency and in 1994 the Republican Party crushed the Democratic Party in the mid-term elections. Clinton's healthcare plan would also crash and burn. Clinton's second term was dominated by the consequences of his personal misconduct with the Intern Monica Lewinsky, leading to formal impeachment proceedings. Despite this, the United States would become the most prosperous in more than a generation under Clinton. The economy achieved sustained growth rates not seen since the 1960s. There would be a 25 year low in violent crime and the unemployment rate of $3.9 \%$ would be the lowest in 30 years. Clinton would champion many causes of the opposition, such as welfare reform and a balanced budget

\footnotetext{
${ }^{142}$ David C. Whitney, The American Presidents: Biographies of the Chief Executives from George Washington through Barack Obama, p.354.

${ }^{143}$ Fred I Greenstein, The Presidential Difference: Leadership Style from FDR to Barack Obama, p.90.

${ }^{144}$ Ibid, p.172.
} 
and he would move the Democratic Party towards the centre of the political spectrum. ${ }^{145}$

Skowronek argues that the Clinton presidency was one of the strangest, as Clinton led in the best of times. ${ }^{146}$ Clinton actively disassociated himself from the standard Reagan had so effectively driven. Clinton promised to take the discussion of political alternatives beyond those of the past. Clinton advocated the third way, which insisted that government was not the root of all evil, but at the same time he argued that the era of big government was over. ${ }^{147}$ Skowronek argued that throughout Clinton's presidency, he seemed to do better in playing against Republican stalwarts than in galvanising his own ranks. He promised to shake things up, but the direction of that shakeup was not always clear. Opposition of this type is certainly more pre-emptive than reconstructive. ${ }^{148}$

The presidencies of Nixon and Clinton both witnessed dramatic constitutional confrontations arising from the personal failing of the two men. In both instances, the unravelling of their presidencies reflected not just the individual frailties, but also that both were confronted with the vehement hostility from many in the political class who simply never reconciled themselves with the legitimacy of their presidencies. ${ }^{149}$ Both men were elected out of sequence, interrupting periods of Democrat and Republican dominance in presidential elections, before it was clear that these periods of party ascendancy were under threat. Both men won the White House with only limited personal mandates. In 1968 and 1992 saw the presence of a maverick third party challenger who acted as the spoiler to keep the dominant party out of government. ${ }^{150}$ While both would win a second term comfortably, it was apparent that neither created a lasting

\footnotetext{
${ }^{145}$ David C. Whitney, The American Presidents: Biographies of the Chief Executives from George Washington through Barack Obama, p.521.

${ }^{146}$ Stephen Skowronek, Presidential Leadership in Political Time: Reprise and Reappraisal, p.80.

147 Bill Clinton, 'Inaugural Address: January 20, 1997,' in My Fellow Americans: Presidential Inaugural Addresses from George Washington to Barack Obama, (USA: Red and Black Publishers, 2009), pp.369-374.

148 Stephen Skowronek, Presidential Leadership in Political Time: Reprise and Reappraisal, p.106.

${ }^{149}$ Daniel Beland and Alex Waddan, 'The Social Policies Presidents Make: Pre-emptive leadership under Nixon and Clinton', Presidential Studies Quarterly, Vol. 54, No. 2, 2006, p.65.

150 lbid, p.68.
} 
coalition at an elite or popular level that would restructure the political landscape. ${ }^{151}$ Overall, what sets pre-emptive leadership apart is that it is not designed to establish, uphold, or salvage any political orthodoxy; 'it is an unabashedly mongrel vision, an aggressive critique of the prevailing political categories and a bold bid to mix them up. ${ }^{, 152}$

\section{The Politics of Articulation}

Skowronek argues that beyond the extremes of a wholesale political reconstruction and a systemic disjunction lie all those moments in political time when established commitments of ideology and interest are relatively resilient, providing solutions, or legitimate guides to solutions, to the governing problems of the day. Presidents of articulation are affiliated with a resilient set of governmental commitments. ${ }^{153}$ Once the new order is established, presidents face a different set of challenges. They are given the task of continuing the vision of their reconstructive predecessor. There often is discord among factions of the governing coalition over what that vision entails. Ultimately their decisions end up alienating substantial components of their support base. ${ }^{154}$

An articulation president has the difficult task of regime management. The overriding political imperatives for affiliates of an established order are to maintain and vindicate the governing commitments of the dominant coalition. That involves serving the interests of the faithful, keeping the agenda timely and responsive to changing demands, and ameliorating factional divisions within the ranks. Whereas reconstructive leaders battle over the government's fundamental commitments of ideology and interest, regime managers are at pains to avoid these debates. They are caught in the challenges of making good on received commitments and holding

\footnotetext{
151 lbid.

152 Stephen Skowronek, Presidential Leadership in Political Time: Reprise and Reappraisal, p.106.

153 Stephen Skowronek, The Politics Presidents Make: Leadership from John Adams to Bill Clinton, p.41.

${ }^{154}$ Aaron Manners, 'Reviewing 'Presidential Leadership in Political Time', December 62010 , www.veepcritique.blogspot.com/2010/12/reviewing-presdiential-ladership-in.html, (1 October 2011).
} 
things together. ${ }^{155}$ Skowronek sees the presidents of articulation as being James Monroe, James Polk, Theodore Roosevelt and Lyndon Johnson.

\section{Articulation of Theodore Roosevelt}

Theodore Roosevelt served as the $26^{\text {th }}$ president of the United States of America from 1901-1909. At the time, Roosevelt was the youngest president to ever hold office. He would be thrust into power following the assassination of President William McKinley. Roosevelt kept McKinley's cabinet intact and promised to continue much of his policies. Roosevelt would win election in his own right in a landslide in 1904. Roosevelt would dedicate much of his presidency arguing that it is the right of the government to inspect the books and records of corporations engaged in interstate commerce and because of this, Roosevelt would be known as the 'trust-buster'. ${ }^{156}$ Roosevelt would also champion the building of the Panama Canal and would sign the Spooner Act authorising the government to negotiate the construction of the canal. At the time Panama was a region of Colombia and in 1903 with encouragement from Roosevelt, rebels declared Panama's independence from Colombia. Work on the canal would begin in 1904 and be completed in $1914 .{ }^{157}$ In his second term Roosevelt would announce an expansion of the concept of the Monroe Doctrine that became known as the Roosevelt Corollary. Roosevelt stated that:

'In the Western Hemisphere the adherence of the United States to the Monroe Doctrine may force the United States, however reluctantly, in flagrant cases of such wrongdoing or impotence, to the exercise of an international police power. ${ }^{158}$

Shortly after this announcement, Roosevelt would use this new power to intervene in Santo Domingo (Dominican Republic), because they were not making good on their payment of foreign debts. ${ }^{159}$ Roosevelt would pass

\footnotetext{
${ }^{155}$ Stephen Skowronek, Presidential Leadership in Political Time: Reprise and Reappraisal, p.31.

${ }^{156}$ David C. Whitney, The American Presidents: Biographies of the Chief Executives from George Washington through Barack Obama, p.225.

${ }^{157}$ Ibid, p.226.

158 Ibid, p.227.

159 lbid.
} 
other landmark legislation including the Pure Food and Drug Act and the Meat Inspection Act to regulate the food industry. Roosevelt would also establish the United States Forest Service and would create five national parks. Perhaps one of Roosevelt's biggest achievements was negotiating an end to the Russo-Japanese war, which won him a Nobel Peace Prize. ${ }^{160}$ Ultimately, Roosevelt dedicated his presidency to defending and confirming the commitments of an established political regime, but within that frame, he negotiated the first major departures from the institutional forms and routine operations of American party governance. ${ }^{161}$

\section{Articulation of Lyndon Johnson}

Lyndon B Johnson (LBJ) had the presidency thrust upon him following the assassination of President John F Kennedy in 1963. Johnson summarised his leadership prospects with his first statement to the nation following the death of President Kennedy: 'At this moment of new resolve... let us continue. ${ }^{162}$ Johnson succeeded to the presidency without having earned an electoral mandate, but he was able to not only build on the shock of Kennedy's death, but to assure the nation that the continuity and stability of government were ensured. ${ }^{163}$

His leadership throughout 1964 was extraordinarily forceful, as he worked to pass the main items of the Kennedy program: tax cuts, civil rights bill, and the anti-poverty program. FDR and the New Deal had given Johnson his basic political identity, to which he added a strong infusion of southern populism. The objectives of the Great Society grew out of FDR's Economic Bill of Rights of $1944 .{ }^{164}$ Johnson's Great Society not only passed major items of Kennedy's programme, but would also provide federal aid for all aspects of education, and increased social security

\footnotetext{
160 lbid.

${ }^{161}$ Stephen Skowronek, The Politics Presidents Make: Leadership from John Adams to Bill Clinton, p.229.

${ }^{162}$ Lyndon B Johnson, 'Address before a Joint Session of Congress', November 27, 1963, Public Papers of the Presidents: Lyndon Baines Johnson, (Washington DC: Government Printing Office, 1966), p.8.

${ }^{163}$ Erwin C Hargrove, The President as Leader: Appealing to the better angels of our nature, p.113. 164 lbid, p.116.
} 
benefits that included medical care for the elderly. Johnson won the 1964 election in a landslide, beating the extreme Republican candidate Barry Goldwater. Johnson would win $61.1 \%$ of the popular vote and would carry 486 electoral votes. ${ }^{165}$

Fred Greenstein argues that,

'Johnson ranks with Henry Clay as one of the most gifted practitioners of the art of the possible in American history. Johnson's political prowess was not coupled to a disposition to assess the feasibility of his policies. In 1965 he led the United States into a military intervention in Vietnam without exploring its costs and consequences. By 1968, there were a half-million American troops in Vietnam, and the Johnson presidency was on the ropes. ${ }^{, 166}$

The mounting political toll of the Vietnam War led to President Johnston announcing to the American people in 1968 that he would not seek reelection. Ultimately, LBJ's decisions surrounding the Vietnam War have clouded his legacy. On the domestic front, LBJ achieved more for African Americans with the passing of the Civil Right and Voting Rights Act, than at any since reconstruction.

Skowronek argues that the, 'tragedy of Lyndon Johnson' is a drama without parallel in modern American politics. It is a story of a master politician who self-destructed at the commanding heights, of an overarching political consensus shattered in a rush of extraordinary achievements, of a superpower that squandered its resources in a remote conflict with people struggling on the fringes of modernity. ${ }^{, 167}$ At his height Johnson expanded the Democratic coalition and arguably achieved more than many other presidencies, a point I will expand on presently. Overall, Johnson and Roosevelt were affiliates of the existing regime who sought

\footnotetext{
${ }^{165}$ David C. Whitney, The American Presidents: Biographies of the Chief Executives from George Washington through Barack Obama, p.339.

${ }^{166}$ Fred I Greenstein, The Presidential Difference: Leadership Style from FDR to Barack Obama, p.74.

${ }_{167}$ Stephen Skowronek, The Politics Presidents Make: Leadership from John Adams to Bill Clinton, p.325.
} 
to improve the regime they were presiding over. In essence a president strongly affiliated with a regime is a defender of the faith. ${ }^{168}$

\section{Skowronek critiqued}

While Skowronek's recurring structure of presidential authority creates a nice fit for the analysis of American presidents across history, it is not without contention. Peri E. Arnold argues that Skowronek's model implies a deterministic reading of presidential leadership: 'Recurring cycles of leadership duplicate each other and contain the same sequence of leadership roles. The implication is that incumbents are captives of the force of the cycle and leadership is a product of the cycle's roles. ${ }^{169}$ Arnold further argues that Skowronek's theory is a subtle reading of the presidency in history, but it may overreach:

'It intimates a mechanical regularity to its cycles and a determinism to its riles, in a way that undermines its promise for further insights on presidential politics.

Skowronek offers a more powerful lens than we have had for understanding how individual leadership projects confront the challenges of the presidency in a particular time and context. It seems unnecessary to weaken that promise for the appearance of predictability. ${ }^{, 170}$

Nothing in politics is straightforward and Skowronek's theory attempts to arrange presidents into one of four distinct groups by a simple two-by-two classification. One dimension of the classification is the strength of the regime, which ranges from strong and commanding to collapsing and discredited. The other dimension is the strength of the president's affiliation with the existing regime. Professor Rick Valley argues that a table of recurring patterns that can be surmised from a two-by-two classification seems very distant from the presidency as it is experienced

\footnotetext{
${ }^{168}$ Rick Valley, 'An overlooked theory on Presidential Politics', 31 October 2003, www.unm.edu/pre/law/articles advise/PolSci Overlooked, (1 September 2011). ${ }^{169}$ Peri E. Arnold, 'Determinism and Contingency in Skowronek's Political Time', Polity, Vol. 27, No. 3, 1995, pp.497. ${ }^{170}$ Ibid, p.508.
} 
by the president, and by citizens, day by day. ${ }^{171} \mathrm{~A}$ president's personal strength does matter greatly and Valley argues that Skowronek dismisses this theory, and specialists on the presidency, aided by recent theories of emotional intelligence, sort presidents according to their interpersonal skills. They also analyse the application of formal and informal powers: how presidents fare with congress under different conditions of party control and by type of policy request, whether they move public opinion when they would like to, and how well they resist the inevitable undertow of public disillusionment. ${ }^{172}$ As discussed in Chapter One, academics have formulated many different prisms to analyse presidential performance and, while a two-by-two classification gives a good overview, one must not view one method in isolation.

Douglas J. Hoekstra makes a valid argument when he argues that politics is far from simplistic. 'It teaches, instead, what might be labelled an 'ambivalent determinism". Within the frames of political time, presidents are initially granted the freedoms attached to testing the limits of their power and building their own narratives. ${ }^{173}$ While Skowronek maintains that he does not wish to use "classification schemes" to force 'every president into one box or another' this is exactly the impression that Skowronek gives. ${ }^{174}$ As mentioned earlier, by creating a two by two classification system, he creates exactly this perception. A prime example of this is the leadership of LBJ.

Politics is fluid and sometimes presidents straddle between two of Skowronek's categories. While Skowronek touches on this fact, his theory does not focus enough on policy achievements that reconstruct American society. While Skowronek argues that LBJ is an articulation president who followed in the footsteps of his mentor FDR, it could well be argued that

\footnotetext{
${ }^{171}$ Rick Valley, 'An overlooked theory on Presidential Politics', 31 October 2003, www.unm.edu/pre/law/articles advise/PolSci Overlooked, (1 September 2011). ${ }_{172}$ Ibid.

${ }^{173}$ Douglas J. Hoekstra, 'The Politics of Politics: Skowronek and Presidential Research', Presidential Studies Quarterly, Vol. 39, No. 2, 1999, p.660.

${ }^{174}$ Stephen Skowronek, The Politics Presidents Make: Leadership from John Adams to Bill Clinton, p.45.
} 
Johnson achieved more for the American people in his presidency than other reconstructive presidents, including President Reagan. This thesis has already touched on the policy achievements of President Johnson, but it is fair to say that LBJ's great society expanded social entitlements more than almost every other president. The Civil Rights Act and Voting Rights Act achieved more for African Americans in achieving equality under the law than at any other time since the American Civil War and this should not be overlooked. LBJ was affiliated to the resilient liberal regime implemented by FDR. Skowronek argues that LBJ achieved some stunning policy victories during his presidency and often straddled the boundaries between articulating and reconstructing the received premises of national politics. ${ }^{175}$ Skowronek also argues that LBJ failed in becoming a great repudiator because "he could not distance himself from the regime his actions were transforming. ${ }^{176}$ Skowronek goes onto say that Johnson lacked the authority to repudiate any interest of significance, he deployed his powers as strategically as he could to serve all and watched in horror as each in turn repudiated him. ${ }^{177}$ Johnson in the first instance would expand the coalition that FDR created and in the 1964 presidential election would claim a sweeping victory over the Republican contender. That coalition would soon break up over the on-going Vietnam War. Bobby Kennedy would lead the charge that would ultimately destroy the presidency of LBJ.

Richard M. Pious raises a very pertinent point when he discusses the case of LBJ. Pious argues that one of Johnson's biggest problems was his, 'feeling of inferiority as a Texan from the southern wing of the party. ${ }^{178}$ Pious argues that 'Skowronek also needs a notion of an establishment that may itself stand at times outside of the dominant political regime and may be in conflict with it. ${ }^{, 179}$ While Skowronek's concept has many positives, Pious argues that:

\footnotetext{
175 lbid p.333.

${ }_{177}^{176} \mathrm{lbid}$, p.28.

177 lbid.

${ }^{178}$ Richard M. Pious, 'Book Review' in Political Science Quarterly, Vol. 109, No. 1 (Spring, 1994) p.172.

${ }_{179}$ Ibid, p.173.
} 
'I am not sure that Skowronek's concept bears the weight of all the different constellations of forces in the American political economy or that it enables us to make complete assessments of what presidents are trying to accomplish when they conform to these forces'. ${ }^{180}$

Pious make a very valid point, especially with the example of LBJ. It could be argued that Skowronek's concept is too rigid, especially when it comes to the case of analysing individual presidents. While Skowronek outlines in his theory that his system does not take into account policy achievements, it is clear that LBJ achieved a great deal and despite his legacy being overshadowed by the Vietnam War, should be remembered as a man who wanted to create a nation free of poverty and create exactly what his administration termed the 'Great Society'.

Pious also raises another valid point when discussing Skowronek. Pious argues that it is not clear what Skowronek means by a "regime". Pious argues that:

'I am not sure whether he means a party coalition and its attendant interest groups (in which case regimes may no longer exist in quite the same way a chronological time progresses) or an external power structure that parties reflect (in which case we need some discussion of the preferred status of the business community after the Civil War) or an equilibrium of group forces (following the pluralists) or a dominant political orthodoxy (ideology and set of programmatic commitments). ${ }^{, 181}$

Pious makes a valid point regarding the lack of explanation for what a "regime" is and Skowronek leaves it up to the reader to draw their own conclusions. Pious's last option as outlined above regarding a dominant political orthodoxy is exactly what Skowronek envisaged a "regime" being. America today is dominated by conservative ideology and rhetoric first advocated by President Reagan. The regime before that was dominated by the FDR Liberal expansion of the welfare state.

Finally, Professor Sidney M. Milkis argues in his critique of Skowronek's theory that there is a real danger that such a classification system might

\footnotetext{
${ }^{180} \mathrm{Ibid}$

${ }^{181}$ Ibid, p.172.
} 
'render presidential leadership insignificant - turn the political struggles of presidents into a lot of 'sound and fury, signifying nothing. ${ }^{182}$ This would be one of the more common critiques when analysing Skowronek. While the arguments are valid and carry some merit, is superior to other theories as it creates an historical approach rather than an ahistorical approach where only modern presidents can be compared. A historical approach when analysing and comparing two or more presidents from a different times is vital, hence it's utility for this thesis.

Overall, despite some reservations about Skowronek's classification system academics have labelled the book The Politics Presidents Make, as monumental and 'a brilliant reading of presidential leadership and as a work that earns a very special place in the library of political science. ${ }^{183}$ The classification system provides a sweeping overview of over 200 years of American presidential history and is an excellent place to start when comparing two or more presidents from across political time. Reagan served as president during the 1980s and Obama was elected president in 2008. During this time the Cold War ended, the Berlin Wall fell and the September 11 terrorist attacks changed the world forever. Despite these momentous events and all of the leadership theories outlined in this thesis, Skowronek's recurring structure of political authority is considered best placed to compare these two presidents who served at two different moments in political time.

\footnotetext{
182 Sidney M. Milkis, 'What Politics do Presidents Make?' in Polity, Vol. 27, No 3, Spring 1995, p. 488. ${ }^{183}$ Douglas J. Hoekstra, 'The Politics of Politics: Skowronek and Presidential Research', Presidential Studies Quarterly, Vol. 39, No. 2, 1999, p.657.
} 


\section{Chapter Three: The ascent to the Presidency - Reagan and Obama before the White House}

\section{Ronald Reagan - From film star to Governor}

'I have spent most of my life as a Democrat. I recently have seen fit to follow another course... You and I are told increasingly we have to choose between a left or right. Well I'd like to suggest there is no such thing as a left or right. There's only an up or down: [up] man's old -- old-aged dream, the ultimate in individual freedom consistent with law and order, or down to the ant heap of totalitarianism. And regardless of their sincerity, their humanitarian motives, those who would trade our freedom for security have embarked on this downward course. ${ }^{.184}$

Ronald Reagan, A Time For Choosing Speech, 1964.

Ronald Reagan was born in Tampico, Illinois on the $6^{\text {th }}$ of February 1911 and spent much of his early childhood moving around the state with his parents Jack and Nelle Reagan. Reagan's father was a shoe salesman who suffered from what Reagan and his older brother Neil called the Irish Disease - alcoholism. Reagan felt strongly about his father despite his alcoholism and often mentioned that his father 'taught him ambition, a belief in the rights of the individual, a suspicion of established authority, and maybe a little something about telling a story. ${ }^{185}$ Reagan attended Eureka College and had his first job as a lifeguard where he performed 77 rescues. Upon leaving College, Reagan took up a career as a radio announcer, broadcasting home football games for the Hawkeyes. In 1937 took a screen test with Warner Brothers, where he landed a film contract. Reagan would go onto star in many films including Knute Rockne: All American, where he played George, 'The Gipper' Gipp. Reagan would acquire a lifelong nickname as the 'Gipper' from starring in that film. ${ }^{186}$

\footnotetext{
${ }^{184}$ Ronald Reagan, 'A Time for Choosing Speech October 27 1964,' (1 $1^{\text {st }}$ June 2008), http://www.reaganfoundation.org, (22 April 2012).

${ }^{185}$ Ronald Reagan, An American Life (New York: Simon and Schuster, 19900, pp. 21-22.

${ }^{186}$ Edmund Morris, Dutch: A Memoir of Ronald Reagan, (London: Harper Collins, 1999), p.167.
} 
In 1938 Regan starred in the film Brother Rat, with actress Jane Wyman. The pair formed a relationship, became engaged at the Chicago Theatre and married on January 26, 1940. The couple had three children together; Maureen Reagan, adopted son Michael Reagan and Christine Reagan who was born prematurely in 1947 and who passed away soon after. Following the death of baby Christine, Reagan's marriage was in difficulties and the couple eventually divorced in 1949. Wyman cited Reagan's growing interest in politics as a major reason for their divorce. ${ }^{187}$ To date Reagan is the only President to have been divorced. ${ }^{188}$

In 1941 Reagan was elected to the Screen Actors Guild and was elected president of the Guild in 1947. It was in 1949, during his time as Screen Actors Guild president, that he met actress Nancy Davis. Reagan would go onto marry Davis in 1952; they had two children together. Patti was born in 1952 and Ron in 1958. The couple formed a close bond that lasted until Reagan passed away in $2004 .{ }^{189}$ Reagan made his last film for Warner Brothers in late 1951 after several disappointing film roles. Reagan's acting skills never fully developed, so he was unable to command the greater depth that roles for older actors required. ${ }^{190}$ In need of a new career, in 1954 he was hired by General Electric to host the General Electric Theatre television program. Reagan hosted 208 episodes of the 30 minute CBS Radio and Television production. The programme had well-known actors appearing in dramatic or comedic settings of their own choosing, with Reagan appearing for several minutes at the beginning and the end of the weekly programme. During this time, Reagan travelled throughout America, touring 185 of General Electric's plants, where he spoke to the workers of the factories throughout America. ${ }^{191}$ General Electric Theatre continued until 1962, when the programme was cancelled due to declining ratings and Reagan's growing

\footnotetext{
187 Ibid.

${ }^{188}$ Matt Slovick, 'The American President,' 1997, http://www.washingtonpost.com/wpsrv/style/longterm/movies/features/dcmovies/americanpresident.htm, (22 April 2012).

189 Jules Tygiel, Ronald Reagan and the triumph of American Conservatism, (New York: Pearson Longman, 2006), pp.81-95.

190 lbid, p.83.

191 lbid, p.83-96.
} 
interest in politics; as, for example, when Reagan criticised the Tennessee Valley Authority as an example of "big government". GE had no choice but to fire Reagan and cancel their sponsorship of the programme. ${ }^{192}$ It was during his time with General Electric that Reagan's transformation from a liberal Democrat to a Conservative Republican took place. ${ }^{193}$

Reagan's early political career began as a liberal Democrat and as a supporter of FDR. As the 1950s wore on, Reagan became disillusioned with the Democratic Party and in 1962 formally changed his allegiance to the Republican Party. At the time Reagan stated, 'I didn't leave the Democratic Party, they left me. ${ }^{194}$ In 1964 Reagan campaigned for the Republican presidential nominee Barry Goldwater. While Goldwater would go onto suffer a heavy defeat to President Johnson, Reagan established himself on the national political scene with his 'Time for Choosing' speech in support of Goldwater.

'You and I have a rendezvous with destiny. We will preserve for our children this, the last best hope of man on Earth, or we will sentence them to take the last step into a thousand years of darkness. ${ }^{, 195}$

During his speech, Reagan talked about the need for limited government in people's lives and he argued that the individual is better able to make decisions rather than the government. ${ }^{196}$

Following his speech, Reagan was approached by Californian Republicans to run for Governor. Reagan campaigned on two main themes: welfare reform and sorting out the anti-war protests at Berkeley. Reagan was elected Governor of California in 1966 by defeating two-term governor Pat Brown. Reagan won by a wide margin, almost $58 \%$ of the

\footnotetext{
192 PBS, 'Online News Hour - Reagan Biography,' http://www.pbs.org/newshour/biography pages/reagan/biography.html, (22 April 2012). ${ }^{193}$ Ibid.

194 Steve F. Hayward, The Age of Reagan: The Fall of the Old Liberal Order 1964-1980, (USA: Three Rivers Press, 2001), p.98.

${ }^{195}$ Ronald Reagan, 'A Time for Choosing Speech October 27 1964,' ( $1^{\text {st }}$ June 2008), http://www.reaganfoundation.org, (22 April 2012).

${ }^{196}$ Ibid.
} 
vote, compared to $42 \%$ for Governor Brown. ${ }^{197}$ Upon winning the Governorship, Reagan inherited a $\$ 200$ million deficit. Reagan immediately set to work as Governor by freezing government hiring and approving tax hikes to balance the budget. Perhaps the most controversial decision of his first term as Governor occurred in the spring of 1969, when Reagan sent in the National Guard to break up a student strike at Berkeley University. The National Guard was armed with bayonets and tear gas and occupied Berkeley for 17 days. The breakup of the protests cost the life of one student. ${ }^{198}$ Reagan won re-election in 1970 by defeating Democrat Jesse M. Unruh. Reagan won 53\% of the vote, compared to $45 \%$ for Unruh. Perhaps the biggest achievement of Reagan's second term came in 1973 when Reagan, who inherited a \$200 million dollar deficit in 1967, produced a $\$ 1.1$ billion dollar budget surplus. Also, the California legislature enacted a compromise on welfare reform, which was largely seen as a success. ${ }^{199}$ The Welfare Reform Act of 1971 was a landmark piece of legislation that became a model for similar measures across the nation. The act simultaneously tightened eligibility requirements while simplifying the needs standards employed to determine inclusion. It also elevated benefits for those remaining on the rolls by $43 \%$ and streamlined bureaucratic costs. During the second term more than 300,000 people were eliminated from the welfare rolls. ${ }^{200}$ Reagan continued on as Governor until 1975 when his eyes turned towards a run for the presidency.

While Reagan briefly ran for president in 1968, it wouldn't be until 1976 when he mounted a serious bid for the White House. Reagan fought a strong primary challenge against President Gerald R. Ford, suffering early setbacks, with losses in the first six states before winning the North Carolina Primary. In the primaries, Ford carried 27 states to Reagans 23,

\footnotetext{
${ }_{197}$ Jeffrey Kahn, 'Ronald Reagan launched his political career using Berkeley campus as a target', (8 June 2004), http://www.berkeley.edu/news/media/releases/2004/06/08 reagan.shtml, (22 April 2012). ${ }_{198}$ Ibid.

199 PBS, 'Timeline: Ronald Reagan's Life' ,www.pbs.org/wgbh/americanexperience/features/timeline/reagan, (14 April 2012). 200 Jules Tygiel, Ronald Reagan and the triumph of American Conservatism, pp.129-130.
} 
but was shy of the 1130 delegates required to win the nomination. ${ }^{201}$ After Ford won the nomination at the Convention, delegates urged Reagan to address the auditorium. Reagan then gave an impromptu speech to the Convention that discussed the dangers of nuclear war and the threat the Soviet Union possessed. Author Lou Cannon stated, 'in a sense, it wasn't a great political speech saying to vote one way or the other... it wasn't political in the sense of dealing with strategy... but it was Reagan's heart... it set him apart from other politicians and political figures at the time. From that day forward, I think American politics changed. ${ }^{202}$ Ultimately Ford would be defeated by Jimmy Carter in 1976. From that moment on Reagan was the front runner to win the Republican nomination and challenge Carter for the presidency in 1980.

\section{Barack Obama - From Hawaii to Community Organiser}

'You see, the challenges we face will not be solved with one meeting in one night. Change will not come if we wait for some other person or some other time. We are the ones we've been waiting for. We are the change we seek... Because we know what we have seen and what we believethat what began as a whisper has now swelled to a chorus that cannot be ignored; that will not be deterred; that will ring out across this land as a hymn that will heal this nation, repair this world, and make this time different than all the rest. Yes We Can. ${ }^{203}$

Barack Obama: Super Tuesday speech, 5 February 2008

Barack Obama's whirlwind assent to the presidency is historic because he was elected as the first African-American president. Obama was born on August 4, 1961 in Honolulu, Hawaii. Two years before Obama was born, his father, Barack Obama Sr. a Kenyan student, won a scholarship to

\footnotetext{
${ }^{201}$ Shirley, Craig, Reagan's Revolution: The untold story of the campaign that started it all, (USA: Nelson Current, 2005), p.328.

202 Ibid, p. 334.

${ }^{203}$ Barack Obama, 'Super Tuesday Election Night Speech', in Mary Frances Berry and Josh Gottheimer (ed.), Power in Words: The Stories behind Barack Obama's Speeches, From the State House to the White House, (Boston: Beacon Press, 2010), p.173-174.
} 
study at the University of Hawaii where he married fellow student Ann Dunham. ${ }^{204}$ Following the marriage, the relationship slowly deteriorated until Obama's mother Ann filed for divorce in 1964. That same year, Obama's mother met another foreign student, Lolo Soetoro from Indonesia. The two spent time dating, until they married in 1967. Obama was just six years old when he moved with his mother and stepfather to Jakarta, Indonesia to live. While in Indonesia, Obama experienced poverty first hand. With the absence of Obama's father, his stepfather Lolo filled the gap and taught him the 'ways of the world'. Lolo taught Obama how to defend himself in an unjust world. ${ }^{205}$ Obama returned to Hawaii when he was ten to live with his grandparents and, with their help, gained a scholarship to attend the prestigious prep school, Punahou. Obama felt the odd one out at school with very few African-American students attending:

'A redheaded girl asked to touch my hair and seemed hurt when I refused. A ruddy-faced boy asked me if my father ate people... The novelty of having me in the class quickly wore off for the other kids, although my sense that I didn't belong continued to grow... A ten-year-old's nightmare.206

In 1972, Obama's mother and half-sister Maya, returned to Hawaii to pursue a master's degree in anthropology at the University of Hawaii. That same year Obama's father returned to Hawaii on his last visit to America. Obama described his father's visit,

'A month. That's how long we would have together, the five of us in my grandparent's living room most evenings, during the day on drives around the island or on short walks past the private landmarks of a family... There was so much to tell in that single month, so much explaining to do; yet when I reach back into my memory for the words of my father, the small interactions or conversations we might have had, seem irretrievably lost. ${ }^{207}$

That was the last time Obama would see his father before he died in a car accident in Nairobi in 1982.

\footnotetext{
${ }^{204}$ Garen Thomas, Yes We Can: A Biography of Barack Obama, (New York: Feiwel and Friends, 2008), p.11. 
Obama travelled to Los Angeles in 1979 to study at the Occidental College and in 1980 took up a new cause: alongside fellow students, Obama organised a delegate from the African National Congress (ANC) to speak on campus about the wrongness of apartheid in South Africa. Obama addressed the campus before the ANC speaker. Even at this early stage, Obama's gift to articulate his message was evident:

'There's a struggle going on. It's happening an ocean away. But it's a struggle that touches each and every one of us. Whether we know it or not. Whether we want it or not. A struggle that demands we choose sides. Not between black or white. Not between rich and poor. No - it's a harder choice than that. It's a choice between dignity and servitude. Between fairness and injustice. Between commitment and indifference. A choice between right and wrong... ${ }^{208}$

Obama's words evoked a powerful response from the audience. The audience wanted more: 'Obama felt energised and ready to take the crowd on a journey with him, on a carpet woven from threads of ideas and strings of words. He could rouse their spirits. His voice carried through the air and penetrated the hearts of those in attendance. He felt he was about to change the world. ${ }^{209}$ Just as Obama was in the swing of things, he was yanked off stage as planned, to represent the evils of apartheid. Instead of feeling satisfied with what he had achieved, Obama felt like a fraud. At this stage in his life he felt that he had no business speaking for African Americans. 'I don't believe that what happens to a kid in Soweto makes much difference to the people we were talking to. ${ }^{210}$ Obama continued to study at Occidental College for two years before transferring to Columbia University in New York where he studied Political Science, majoring in International Relations. Obama lived in New York for four years and spent two of those years working at the Business International Corporation and the New York Public Research Group.

In 1985 Obama made the decision to move to Chicago, to become a community organiser at the Developing Communities Project. Community

\footnotetext{
${ }^{208}$ Ibid, p.106.

${ }^{209}$ Garen Thomas, Yes We Can: A Biography of Barack Obama, p.70.

${ }^{210}$ Barack Obama, Dreams from My Father: A Story of Race and Inheritance, p.109.
} 
organiser, Gerald Kellman hired Obama to work in the, 'demoralised landscape of poor neighbourhoods on Chicago's South Side. ${ }^{211}$ Serge Kovaleski of the New York Times wrote in 2008, that Obama's three years as a grass-roots organiser had 'figured prominently, if not profoundly, in his own narrative of his life. Campaigning in lowa in $2008 \mathrm{Mr}$ Obama called it 'the best education I ever had, better than anything I got at Harvard Law School,' an education that he said was 'seared into my brain. ${ }^{212}$ Obama devoted about one-third of the 442 pages in his memoir, Dreams From My Father, to chronicling that Chicago organising period. ${ }^{213}$ While Saul Alinsky, a Chicago native regarded as the father of community organising, viewed self-interest as the main motivation for political participation, Obama saw it more broadly. Fellow organiser, Daniel Lee would recall that Obama's view was, 'figuring out who you are and then getting that person to think about what he or she is going to do with it is the first step towards empowerment. ${ }^{214}$ Obama also shunned Mr Alinsky's strategy of 'using confrontation tactics like pressuring public officials and business leaders by picketing their homes. ${ }^{215}$ Gerald Kellman believed that, "it was strategic that he (Obama) would not have fallouts with people he disagreed with because he realised that he had to work with them not just on one particular issue, but on other issues down the road. ${ }^{216}$ While Obama was an organiser he achieved many small gains for those living in the South Side of Chicago. Despite these gains, Obama was reminded by Gerald Kellman that 'small triumphs don't amount to big changes in this world. Small wins were only meant to fill people with the courage to fight for bigger things. ${ }^{217}$ By 1988, Obama knew it was time to move on and applied for and was accepted to study at Harvard Law School.

Before commencing study at Harvard Law School, Obama travelled to Kenya to visit the homeland of his father. Obama travelled to the village of

\footnotetext{
${ }^{211}$ Serge Kovaleski, 'Obama's Organizing Years, Guiding Others and Finding Himself, July 72008 , www.nytimes.com/2008/07/07/us/politics/07community.html, (7 April 2012).

212 Ibid.

${ }^{213}$ Ibid.

${ }^{214}$ Ibid.

215 Ibid

${ }^{216}$ Ibid.

${ }^{217}$ Garen Thomas, Yes We Can: A Biography of Barack Obama, p.109.
} 
Alego, his father's village and met his grandmother, half siblings, cousins and extended family. Obama learned much about his father while in Kenya. He learned of the struggles his father had faced on a daily basis. The trip to Kenya had a profound effect on Obama and it also helped answer many unanswered questions:

'Obama knelt in the backyard between the gravestones of his father and grandfather and cried, releasing the pain he'd felt for not knowing all those years what they had been through, realising the anger he had at his dad for not being there to guide him. Now it was time for him to rise up and let go of the stranglehold of his past. He would no longer live in a figment's shadow. His dad was real. At last he was human. ${ }^{218}$

Following his trip to Kenya, Obama returned to America to take up study at Harvard University, where he studied law. Obama was active at Harvard, writing several articles in the Harvard Civil Rights-Civil Liberties Law Review on anti-apartheid. Obama spoke at the Black Law Students Association annual dinner and stressed the need for people like him, who had been given many opportunities in life, to give back and help those who hadn't been as fortunate. ${ }^{219}$ At the end of his first year at Harvard Law School, Obama returned to Chicago to work as an intern at the Sidley Austin law firm where he met attorney Michelle Robinson who was assigned to train him. Obama was immediately attracted to Michelle and the couple began dating only after Michelle set Obama up on a date with a friend. The couple continued dating on a long distance relationship after Obama returned to Harvard Law School. ${ }^{220}$

Obama was elected as the first African American president of the Harvard Law Review during his second year at Harvard Law School. This was an historic achievement, as the presidency of Harvard Law Review is usually seen as a springboard to prominence and power. ${ }^{221}$ Despite being liberalminded, Obama was open minded and would listen to both sides of an issue before forming a conclusion. Obama was respected by both

\footnotetext{
${ }^{218}$ Ibid, p. 124.

${ }^{219}$ Ibid, p. 130.

220 lbid.

${ }^{221}$ James T. Kloppenberg, Reading Obama: Dreams, Hope and the American Political Tradition, (Princeton: Princeton University Press, 2011), p.48.
} 
conservatives and liberals during his tenure as president of the law review. ${ }^{222}$ He graduated in 1991, with a Juris Doctor Magna cum laude. Obama was in huge demand: when Miner, Barnhill and Galland from Chicago contacted the Law Review office to offer Obama a job, they were the $647^{\text {th }}$ firm to offer work. Obama accepted the offer from Miner, Barnhill and Galland because of their work with victims of discrimination and civil rights abuses; and because of their proximity to Michelle Robinson. ${ }^{223}$

Upon returning to Chicago, Obama spent the first six months of 1992 working as the director of the Illinois Project Vote focussed on registering minority voters. The Project registered approximately 150,000 new voters, mainly in the African American community. Also in 1992, Obama married Michelle Robinson at the Trinity United Church of Christ in Chicago, officiated by Reverend Jeremiah A. Wright. ${ }^{224}$ Reverend Wright would become a campaign issue when Obama ran for president in 2008. This will be discussed in Chapter Five of this thesis.

In November 1995, Obama's mother Anne passed away after a long battle with ovarian cancer, while he was campaigning for an Illinois State Senate Seat. Also in 1995, the first of Obama's two books was released, Dreams from My Father. The book retraces the early steps of his life and his constant grapple with his race and identity. Obama won the Illinois $13^{\text {th }}$ senate district in a landslide with $82 \%$ of the vote. He won re-election in 1998 and 2002 by wide margins. During his time as a state Senator, Obama taught Constitutional Law part-time at the University of Chicago Law School. During his time as State Senator the Democrats were in the minority, which often made it difficult for Obama to pass legislation. His time in the Illinois State Senate would have been invaluable as he would have learned how to compromise and how negotiate to achieve his agenda. He did, however manage to pass a variety of laws with bipartisan support, including a prostate-screening initiative, increased funding for after-school programs, the removal of lead from homes, AIDs prevention

\footnotetext{
${ }^{222}$ Garen Thomas, Yes We Can: A Biography of Barack Obama, p.132.

${ }^{223}$ Ibid, p.133.

${ }^{224}$ Ibid, p.138.
} 
programs and healthcare access for low-income families. Obama also passed campaign finance reform and triumph with increased scrutiny of racial profiling by police and a law that required police to video tape their interrogations of murder suspects. ${ }^{225}$

In 1999 Malia, the Obama's first daughter was born and that same year Obama announced his candidacy to run for Congress in the mainly African American Illinois first congressional district. Obama challenged incumbent Democrat Bobby Rush in a bruising primary. Rush had been a leader of the Black Panther Party in Illinois, and he constantly accused Obama of not being 'black enough,' throughout the campaign. When Rush's son was gunned down in October 1999 and Obama missed an important vote on Governor George Ryan's Safe Neighbourhoods Act, a gun control law, his campaign seemed headed for the scrapheap. Obama suffered his only electoral defeat in the March 21, 2000, Democratic Primary. Obama won less than $30 \%$ of the vote compared to nearly $60 \%$ for Rush. ${ }^{226}$

In 2001, Obama's second daughter Natasha (often called Sasha) was born and in 2004 Obama ran for election to the United States Senate. After winning the Democratic primary with $54 \%$ of the vote, Obama fended off the challenge of Republican candidate Allan Keyes after Republican Jack Ryan dropped out after an alleged sex scandal. Obama won an unprecedented $70 \%$ of the vote compared to $27 \%$ for Keyes. Obama's victory was the biggest in Illinois history of Senate elections. With Obama's election to the Senate, he became only the third African American to serve as a senator since Reconstruction. ${ }^{227}$ Before election to the Senate, Obama rose to national prominence with his speech at the 2004 Democratic Convention. In his speech, Obama would speak of a unified America.

\footnotetext{
225 lbid, p.141.

${ }^{226}$ Ibid, p. 143.

${ }^{227}$ Garren Dorrien, The Obama Question: A Progressive Perspective,p.2.
} 
'Well, I say to them tonight, there is not a liberal America and a conservative America - there is the United States of America. There is not a black America and a white America and Latino America and Asian America - there's the United States of America. The pundits like to slice-and-dice our country into Red States and Blue States; Red States for Republicans, Blue States for Democrats. But I've got news for them, too: We worship an awesome God in the Blue States, and we don't like federal agents poking around in our libraries in the Red States. We coach Little League in the Blue States, and, yes, we've got some gay friends in the Red States. There are patriots who opposed the war in Iraq and there are patriots who supported the war in Iraq. ${ }^{\text {228 }}$

From that moment on, Obama, like Reagan with his Time For Choosing Speech in 1964 sprang onto the national sphere, with many concluding that he had the ability to one day be elected the President of the United States.

Obama was officially sworn in as a United States Senator on January 4, 2005, and during his tenure as the Junior Senator of Illinois, served on many committees, including as Chair of the United States Senate Foreign Relations Subcommittee on European Affairs. ${ }^{229}$ Obama co-sponsored the Secure America and Orderly Immigration Act with fellow senators John McCain (Arizona) and Edward Kennedy (Massachusetts). The legislation aimed to find a way to control illegal immigration into the United States. Unfortunately for Obama, the bill was defeated in the House of Representatives. Obama also worked with Conservative Republican Tom Coburn on several bills, including the Federal Funding Accountability and Transparency Act, which allows Americans to see online how their tax dollars are spent. Perhaps the most significant legislative achievement was joining Senator Richard Lugar (Indiana) on a fact-finding mission in 2005 to Eastern Europe, looking for stockpiles of weapons from the former Soviet Union. The Lugar-Obama Act was aimed at aiding the ability of the State Department to help the former Soviet Union find and

\footnotetext{
${ }^{228}$ Barak Obama, The Audacity of Hope: Thoughts on Reclaiming the American Dream, (New York: Crown Publishing, 2006), p.231.

${ }^{229}$ Garen Thomas, Yes We Can: A Biography of Barack Obama, p.166.
} 
forbid the production or stockpiling of weapons. The bill was signed into law by President Bush in January 2007..$^{230}$

In 2006, Obama's second book The Audacity of Hope was released to wide acclaim. The book is a wide ranging discussion on the issues that face America today. Three months after the release of this book, on a cold winter's day in Springfield, Illinois, Obama announced his candidacy for President of the United States.

'It was here, in Springfield, where North, South, East, and West come together that I was reminded of the essential decency of the American people - where I came to believe that through this decency, we can build a more hopeful America. And that is why, in the shadow of the Old State Capitol, where Lincoln once called on a divided house to stand together, where common hopes and common dreams still live, I stand before you today to announce my candidacy for President of the United States. ${ }^{231}$

From this moment on, Obama would embark on a gruelling battle against former First Lady and New York Senator, Hillary Clinton. While Chapter Five will discuss the 2008 Democratic primary campaign, Obama's grassroots campaign and superior fundraising ability would ultimately win him the nomination. ${ }^{232}$

\footnotetext{
${ }^{230}$ Ibid, p.169.

${ }^{231}$ Mary Frances Berry and Josh Gottheimer, Power in Words: The Stories behind Barack Obama's Speeches, from the State House to the White House, (Boston: Beacon Press, 2010), p.109. ${ }^{232}$ John Heilemann and Mark Halperin, Race of a Lifetime: How Obama won the White House, (New York: Viking Press, 2010).
} 


\section{Chapter Four: Paradigm changing elections}

Skowronek argues that American government and politics are transformed when new interests secure a firm grip on power, and the elections of 1980 and 2008 brought about new governing coalitions in America. This chapter will analyse the elections of 1980 and 2008 when Reagan and Obama were elected president. The 1980 and 2008 presidential elections will be remembered as landmark elections when the American public threw out the ruling party for an alternative leader promising to change the direction of the country. Reagan and Obama managed to hold those coalitions together in 1984 and 2012 to win reelection, something that is much harder today than it was for other reconstructive presidents. This Chapter will also outline the 1980 Republican and 2008 Democratic nominating contests, when Reagan and Obama won their respective party's nomination. This Chapter provides firm evidence of Reagan's reconstruction and the potential for an Obama reconstruction.

\section{0 and the rebirth of the Republican Party}

'Next Tuesday all of you will go to the polls, you will stand there in the polling place and make a decision. I think when you make that decision, it might be well if you would ask yourself, are you better off than you were four years ago? Is it easier for you to go and buy things in the stores than it was four years ago? Is there more or less unemployment in the country than there was four years ago? Is America as respected throughout the world as it was? Do you feel that our security is as safe, that we're as strong as we were four years ago? ${ }^{233}$

Ronald Reagan: 1980 Presidential Debate Closing Statement

By 1980 America was at a cross road. The American economy was struggling and 44 Americans were being held hostage in Iran. As the

\footnotetext{
${ }^{233}$ Commission on Presidential Debates, 'October 281980 Debate Transcript: The Carter-Reagan Presidential Debate', 2009, http://www.debates.org/index.php?page=october-28-1980-debatetranscript, (6 March 2012).
} 
presidential election of 1980 approached, America was caught in 'a maelstrom of economic, social, and foreign woes that presaged not only a difficult re-election campaign for incumbent president Jimmy Carter, but the potential for a broader break with the past. ${ }^{, 234}$ Carter's response to the deepening crisis was to return to Washington from an extended stay at Camp David, to deliver his 'Crisis of Confidence' speech to the nation:

'It is a crisis that strikes at the very heart and soul and spirit of our national will. We can see this crisis in the growing doubt about the meaning of our own lives and in the loss of a unity of purpose for our nation. The erosion of our confidence in the future is threatening to destroy the social and the political fabric of America... We've always had a faith that the days of our children would be better than our own. Our people are losing that faith. ${ }^{235}$

That speech was soon described as the "malaise speech". America was on a downward spiral and Carter implied that the American people had failed. This was the opening that Carter's opponents both from the Republican Party and even his own party needed. ${ }^{236}$ The political Democratic Coalition that had existed and dominated since the New Deal was on the ropes and the Conservative movement was starting to fly. The major reason for this was the state of the American economy.

'In the mid-1960's, the United States economy had been a model of job creation, increasing wages and low inflation (1.3\% in 1964). As the costs of the Great Society and the Vietnam War escalated, costs paid in both taxes and deficits, inflation began to climb. The Dow Jones Industrial peaked in 1973 at around 1,050 , and did not regain that level for the rest of decade. The good times were over. ${ }^{237}$

America slipped into recession in 1969, and in 1970 inflation stood at 5.7\%. In 1971 President Nixon imposed federal wage and price controls in an effort to stop price rises and the dollar was devalued. The first oil shock hit in 1973 and by 1974 inflation was at 11\%. By 1975 unemployment stood at $8.5 \%$. Since the late 1960 s the American economy had been experiencing difficulties, and 1973 was the point at which economic

\footnotetext{
${ }^{234}$ Andrew E Busch, Reagan's Victory: The Presidential Election of 1980 and the rise of the right, (USA: University of Kansas Press, 2005), p.1.

${ }^{235}$ Ibid, p.5.

${ }^{236}$ Ibid.

${ }^{237}$ lbid, p.6.
} 
indicators, including productivity, the basis for future prosperity, headed downward for the rest of the 1970s. The poverty rate reached an historic low of $11.1 \%$ in 1973 , before climbing again. ${ }^{238}$

Between 1960 and 1980, the federal government continued expanding in size and during this time federal spending increased from $\$ 92$ billion to $\$ 591$ billion and federal revenues jumped from $\$ 92$ billion, to $\$ 517$ billion. Even adjusted for inflation, spending doubled. In 1979 the top federal income tax rate was $70 \%$ and the fourteen tax brackets were not indexed to inflation. This meant that working families were being increasingly pushed into higher brackets because of raises that had not kept up with inflation. ${ }^{239}$ For example, a family making $\$ 25,000$ in 1978 would have seen the tax rate on its last dollar of income increase from 19\% in 1968 to $28 \%$ in 1978 if its income had exactly kept pace with inflation. ${ }^{240}$ By 1980 , individuals had become increasingly weary of the role of government.

\section{The Republican Nomination}

In the Republican primaries, Reagan was the favourite to win the nomination. In 1976 Reagan challenged President Gerald Ford for the Republican nomination, only to fall short at the Republican Convention. Four years later, economic conditions were ripe for a conservative takeover of the Republican Party. However, Reagan would suffer an early defeat in the lowa Caucus to George H.W Bush. Bush would win 32\% in the lowa Caucus, compared to $30 \%$ for Reagan. ${ }^{241}$ Reagan fought a comeback to convincingly win the New Hampshire Primary a month later. Reagan scored $50 \%$ in the primary, compared to just $23 \%$ for Bush. The major highlight of the primary came with the Nashua Telegraph sponsored debate. The Telegraph wanted to limit the debate to the two frontrunners, Reagan and Bush. But when the Federal Election Commission ruled in favour of a complaint from Bob Dole that the format constituted an illegal

\footnotetext{
${ }^{238}$ Ibid, p.8.

239 lbid, p.10.

240 lbid.

${ }^{241}$ Craig Shirley, Rendezvous with Destiny: Ronald Reagan and the Campaign that Changed America, (Delaware: Isi Books, 2010), p.103.
} 
campaign contribution by the Telegraph to Reagan and Bush, Reagan agreed to pick up the cost from the newspaper and invite the other five major candidates. Bush appeared to be caught unawares and preferred to return to the original arrangement. When Reagan tried to address the restless crowd, Nashua Telegraph editor Jon Breen tried to shut off his microphone. Without missing a beat, Reagan retorted, "I'm paying for this microphone Mr Green." ${ }^{242}$ Reagan came across as generous and firm and was the crowd favourite, compared to Bush who looked stiff and struggled throughout the debate. This would be a key turning point in the Republican primaries. Overall, Reagan would carry 44 states and win $59.79 \%$ of the popular votes, compared to Bush who won 6 states and won $23.81 \%$ of the vote. ${ }^{243}$ The conservative takeover of the Republican Party was complete.

\section{The Race for President}

President Jimmy Carter was challenged by Massachusetts Senator Edward Kennedy. While Carter would prevail and win the nomination, many in the Democratic Party were left disappointed and disillusioned with the choice of candidate. ${ }^{244}$ During the general election campaign, the economy dominated, as well as the Iran hostage crisis, where a band of student revolutionaries stormed the American embassy in Tehran and took all Americans hostage. The revolutionaries threatened to kill the hostages if the United States did not return the recently deposed Shah of Iran, Mohammed Rica Pahlavi to Iran to face punishment. The Shah had been granted entry into the United States to receive medical treatment. ${ }^{245}$ Carter's handling of the crisis and the failed rescue attempt would overshadow other foreign policy successes, such as the Camp David accords between Israel and Egypt. ${ }^{246}$ Paul F Boller argues:

\footnotetext{
242 lbid, p.67.

243 lbid, p.312.

244 Edward M Kennedy, True Compass, (USA: Little Brown publishing, 2009), p.381.

245 Paul F. Boller, Jr, Presidential Campaigns: From George Washington to George W. Bush, (New York: Oxford University Press, 2004), p.355.

246 Ibid, p.354.
} 
'The hostage crisis probably helped Carter win his party's nomination; in the ensuing state primaries and party caucuses he went on to win more delegates than Kennedy and more than enough to obtain a first-ballot nomination at the Democratic national convention. But the deadlock in negotiations with Iran for the release of the hostages hurt him badly. And the failure of the helicopter raid to rescue the hostages in April may well have dealt him a fatal blow. ${ }^{247}$

Carter's chief strategist, Hamilton Jordan described the crisis:

'The hostage crisis had come to symbolise the collective frustration of the American people. And in that sense, the President's chances for re-election probably died on the desert of Iran with eight brave soldiers who gave their lives trying to free the American hostages. ${ }^{248}$

Despite this, Reagan did not have the campaign to himself and throughout the campaign the polls remained close between Reagan and Carter. Steven F. Hayward argues that 'the principal task for Reagan at the outset of the campaign was to cement his plausibility to be president and make Carter the central issue of the election. ${ }^{249}$ The problem was that too often, Reagan would make himself as much the main issue of the campaign, as Carter. Hayward argues that Reagan's problems stemmed from his greatest personal strength: his candour and his fearlessness about saying what he really thought. ${ }^{250}$ One such gaffe occurred on August 16, 1980, when Reagan remarked at a news conference that he believed the United States should have 'an official government relationship' with Taiwan, which implied reversing not only United States policy towards China, but repealing the Taiwan Relations Act that Congress had enacted in 1979. This occurred at the same time as Reagan's running mate George H.W Bush was on his way to Beijing. The visit was a disaster. ${ }^{251}$

Perhaps Reagan's most serious gaffe occurred on September 1. While Carter was opening his fall campaign in Alabama, Reagan was campaigning at the Michigan State Fair. A woman wearing a Carter mask walked by, heckling Reagan. Reagan took exception and commented:

\footnotetext{
${ }^{247}$ lbid, p.356.

248 lbid.

${ }^{249}$ Steve F. Hayward, The Age of Reagan: The Fall of the Old Liberal Order 1964-1980, p.678.

${ }^{250}$ Ibid.

251 lbid.
} 
'I thought you were in Alabama today. You know, I kind of like the contrast, though. I'm happy to be here, where you're dealing at first hand with the economic problems that have been committed, and he's opening his campaign down in the city that gave birth to the Ku Klux Klan., 252

The remark was met with gasps from the crowd and Reagan immediately regretted the remark. The remark was wrong and Reagan was forced to telephone and apologise to the Mayor of Tuscumbia, Alabama. ${ }^{253}$ With this, Carter had his opening and went on the offensive against Reagan.

Carter opened a barrage of attacks against Reagan, playing what the New Republic labelled the 'Race Card'. The media were harsh on Carter, who implied Reagan was a racist. The New Republic stated, 'President Carter has made a grave moral error in trying to portray Ronald Reagan as a racist. ${ }^{254} \mathrm{~A}$ major turning point against Carter came on October 6 , when Carter 'let fly with his most self-destructive comment of the campaign. Appearing in a back yard setting, ${ }^{, 255}$ Carter stated,

'You'll determine whether or not this America will be unified or, if I lose the election, whether America might be separated, black from white, Jew from Christian, North from South, rural from urban. ${ }^{256}$

Reporters could not believe the outburst from Carter and Reagan retorted:

'I just have to say this. I can't be angry. I'm saddened that anyone, particularly someone who has held that position, could intimate such a thing. I'm not asking for an apology from him. I know who I have to account to for my actions. But I think he owes the country an apology. ${ }^{257}$

The media were scathing of Carter's comment and NBC's Chris Wallace said, 'Carter's comment showed Mr Carter as mean and un-presidential and Reagan as caring and mature. ${ }^{258}$ Reagan's campaign strategist

\footnotetext{
252 Ibid, p.694.

${ }^{253}$ Ibid, p.695.

${ }^{254}$ Ibid, p.698.

${ }^{255}$ Ibid, p.699.

256 lbid.

257 Ibid.

258 Ibid.
} 
Richard Wirthlin thought that, with that comment, Carter almost gifted Reagan the election. ${ }^{259}$

By October, 14 a CBS/New York Times poll, gave Carter a one point edge over Reagan. But what was striking was the large number of undecided voters. In 1976 only $6 \%$ of voters described themselves as undecided in mid-October, but in 1980, $20 \%$ of voters were undecided. This suggested that independent or swing voters were unhappy with Carter, but were still uncomfortable with Reagan. ${ }^{260}$ Exactly one week before polling day, when Reagan and Carter went head to head in a debate. Around 100 million people tuned into the debate, the largest political broadcast in American history. Walker Cronkite introduced the debate by stating, 'It's not inconceivable that the election could turn on what happens in the next 90 minutes. ${ }^{261}$ Both candidates were nervous, but Carter never fully relaxed and appeared stiff and uptight throughout. Reagan on the other hand had the final say of the debate and landed the fatal blow in his closing statement. The closing statement (quoted at the beginning of this chapter) summed up the entire Carter presidency and left the decision squarely in the hands of the voters. Instant polls conducted immediately after the debate gave it to Reagan by a two-to-one margin. Following the debate internal polls from both campaigns started moving in Reagan's direction. $^{262}$

At 2pm on Election Day the first exit polls were released to news organisations and television networks. The news organisations and networks, who were expecting a close race, faced a dilemma of what to do with the stunning results. As NBC opened its bulletin at 7pm Eastern Standard Time, anchor John Chancelor stated, 'according to an NBC-AP poll, Ronald Reagan appears headed for a substantial victory,' even though the polls were still open in 44 states. ${ }^{263}$

\footnotetext{
259 lbid.

260 Shirley, Craig, Rendezvous with Destiny: Ronald Reagan and the Campaign that Changed America, (USA: ISI Books, 2009).

${ }^{261}$ Steve F. Hayward, The Age of Reagan: The Fall of the Old Liberal Order 1964-1980, p.705.

262 Ibid, p.710.

263 Ibid, p.711.
} 


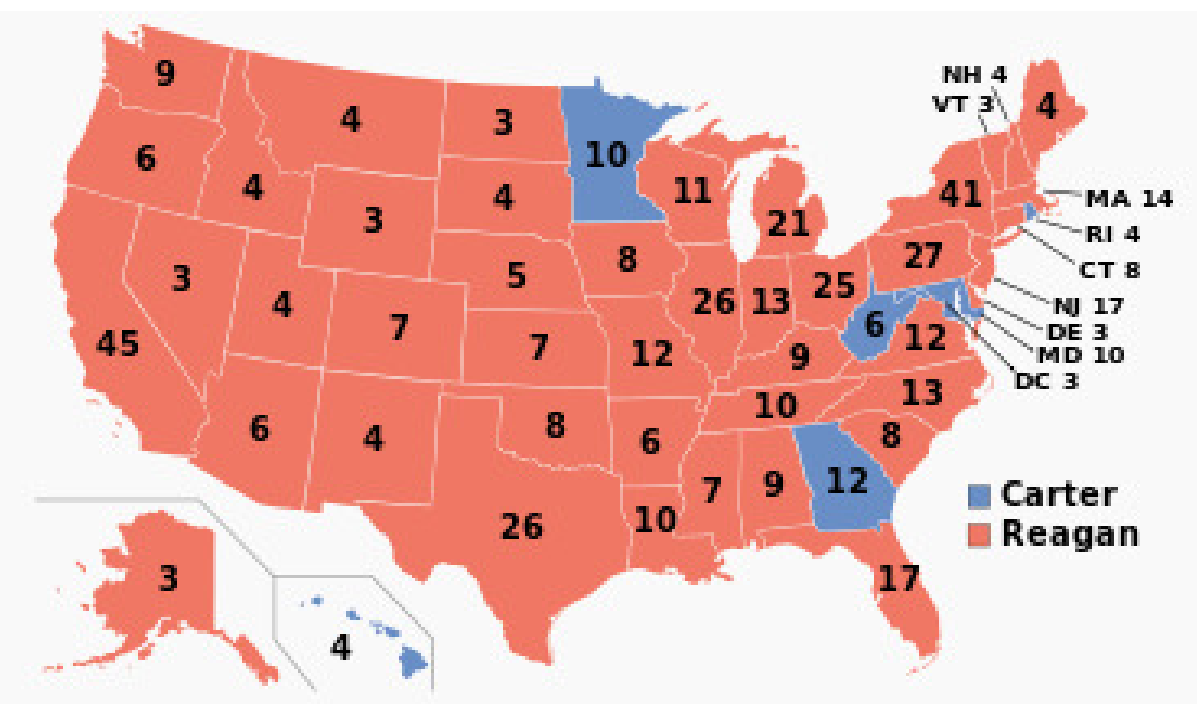

Figure One: 1980 Presidential Election Results ${ }^{264}$

As Figure One above shows, incumbent Jimmy Carter would only win six states and would be trounced by Reagan. Carter's defeat was the most resounding of an incumbent since Herbert Hoover lost to Franklin Roosevelt by $18 \%$ in 1932 . Reagan would win $50.7 \%$ of the vote and win 489 electoral votes compared to $41 \%$ of the vote and just 49 electoral votes for Carter. The result was so clear that Carter conceded the election even before the polls closed on the West Coast. ${ }^{265}$ The one-sided result showed deep dissatisfaction with the Carter presidency. Regan's platform represented a clear break from the political discourse of the previous fifty years. Not only did the Republicans win the White House, they also won control of the Senate for the first time since 1952. Although the Democrats held onto the House, the Republicans picked up 33 seats. ${ }^{266}$ Reagan's electoral coalition would be made up of evangelical Christians, seniors, males and former working class democratic voters. Evangelical Christians would form the base of the Republican Party until today. Reagan's governing coalition would not be rivalled for 28 years, until Obama's governing coalition would become the new force. Reagan and the Republicans had the victory they required to reconstruct America and

\footnotetext{
${ }^{264}$ US Election Atlas, '1980 Presidential Election Results', http://uselectionatlas.org/RESULTS/, (4 October 2012).

${ }^{265}$ Yanek Mieczkowski, The Routledge Historical Atlas of Presidential Elections, (New York: Routledge, 2001), p.133. ${ }^{266}$ Ibid, p.132.
} 
break away from the dominant political discourse that had prevailed over the past fifty years.

\section{8 and change comes to America}

'If there is anyone out there who still doubts that America is a place where all things are possible; who still wonders if the dream of our founders is alive in our time; who still questions the power of our democracy, tonight is your answer. ${ }^{267}$

Barack Obama: Election Night 2008 Victory Speech

Like 1980, America in 2008 stood at a crossroad. Two thousand and eight was the first time since 1952 that neither the incumbent president nor the incumbent vice-president was a candidate in the general election. It was also the first time since 1928 that neither the incumbent president nor the incumbent vice-president sought their party's nomination for president. ${ }^{268}$

The Democratic Nomination

The contest for the Democratic nomination was also wide open with first lady and New York Junior Senator, Hillary Clinton the front runner to win the nomination in the lead up to the lowa caucus. Other candidates included 2004 Democratic Vice Presidential candidate John Edwards, Barack Obama and New Mexico Governor Bill Richardson. Clinton, Obama and Richardson each had the potential to break new ground. Never had a female, African-American or Hispanic been a presidential nominee for either major party. Throughout much of 2007, Clinton held a commanding lead in the polls, ahead of Edwards and Obama. On November 12, 2007 six candidates spoke at the lowa Democratic Party's Jefferson Jackson Dinner in Des Moines. Obama was seen as the winner

\footnotetext{
${ }^{267}$ Barack Obama, 'Election Night Victory speech', in Mary Frances Berry and Josh Gottheimer (ed.), Power in Words: The Stories behind Barack Obama's Speeches, From the State House to the White House, (Boston: Beacon Press, 2010), p.251.

${ }^{268}$ Alan I. Abramowitz, 'How Obama Won the White House,' in Larry Sabato et al, The Year of Obama: How Barack Obama Won the White House, (USA: Pearson Education Inc., 2010), p.91.
} 
after delivering a stinging repudiation of George W. Bush's presidency and drawing Clinton into the speech. Obama stated:

'When I am this party's nominee, my opponent will not be able to say that I voted for the war in Iraq; or that I gave George W. Bush the benefit of the doubt on Iran; or that I supported Bush-Cheney policies of not talking to leaders that we don't like...,269

The speech drew a positive reaction and it began an upswing of support for Obama in lowa. In late 2007, Obama would receive the endorsement of Oprah Winfrey after Clinton received the endorsement of leading African-American Democrats such as Representative John Lewis of Georgia, Charles Rangel of New York and former Atlanta Mayor Andrew Young. Despite this endorsement, Obama was struggling with AfricanAmerican voters, who worried that prejudice rendered him unelectable. For instance, a December 2007 Gallup poll showed African-American Democrats preferring Clinton over Obama by a margin of 53-39\%. ${ }^{270}$ Obama needed to prove he could be electable.

Obama would clinch victory in the lowa Caucus, by securing nearly $38 \%$ of the vote, ahead of Edwards with $29.7 \%$, and Clinton with $29.4 \%$ of the vote. Obama had the victory he required and what was most spectacular was that 229,000 caucus-goers voted in the Democratic lowa caucus, nearly double the number that voted in $2004 .{ }^{271}$ Following the lowa caucus, polls showed Obama moving ahead in the polls in New Hampshire. However, Clinton would not roll over and lead the fight back in the days before the New Hampshire primary. Kate Phillips of The Caucus Blog argues that, in the Manchester debate, 'Clinton displayed poise and toughness when Edwards and Obama seemed to gang up on her. She merged the 'change and experience themes with an effort to shed the special interest tag. ${ }^{, 272}$ Clinton remarked,

\footnotetext{
269 lbid, p. 109.

270 lbid, p. 111.

271 lbid, p.114.

272 Ibid, p. 115.
} 
I've been running on thirty-years of change. I'm running on having taken on the drug companies and health insurance companies, and taking on the oil companies. $^{273}$

Clinton was on the attack and on the morning before the primary, a voter asked Clinton how she held up under adversity. Clinton responded,

'You know, this is very personal for me. It's not just political. It's not just public. I see what's happening, and we have to reverse it. Some people think elections are a game, lots of who's up or who's down. It's about our country. ${ }^{274}$

As Clinton responded, her eyes welled up and her voice cracked. Clinton had been behind in the polls in the lead up to New Hampshire, but with Clinton expressing compassion instead of anger, portrayed a new side to her character. Clinton received intense media coverage of the incident, and dominated the media cycle in the last 24 hours before the polls opened for the New Hampshire primary. ${ }^{275}$ Clinton pulled off the comeback and narrowly won the New Hampshire primary, by winning $39.1 \%$ to beat Obama, with $36.5 \%{ }^{276}$ Any hopes that Obama had of wrapping up the nomination quickly were dashed after Clinton's comeback victory in New Hampshire.

Eleven days after New Hampshire, Clinton won the popular vote in the Nevada Caucus. Despite Clinton winning the popular vote, Obama won more delegates due to a better understanding of the rules. Obama won in precincts with an odd number of delegates, meaning that he often won two delegates to Clinton's one. ${ }^{277}$ Obama also won the African American vote after losing the vote to Clinton in New Hampshire. The reason for the shift in African American support to Obama from Clinton was Bill Clinton's remark that Obama's 2002 Iraq speech was the sum total of his

\footnotetext{
${ }^{273}$ Hillary Clinton, Democratic Presidential Candidates Debate in Manchester, New Hampshire, January 5, 2008, http://www.presidency.ucsb.edu/ws/index.php?pid=76224, (Assessed 16 October 2012).

${ }^{274}$ Kate Phillips, "The Clinton Camp Unbound," The Caucus, January 8, 2008, http://thecaucus.blogs.nytimes.com/2008/01/08/the-clinton-camp-unbound/, (Assessed 16 October 2012).

${ }^{275}$ Ceaser, Bush, Pine, Epic Journey - The 2008 Election and American Politics, (New York: Rowan and Littlefield, 2011), p.115.

${ }_{276}^{27 b i d, ~ p .116 . ~}$

277 Ibid, p.116.
} 
involvement in the early Iraq debate. Clinton called Obama's claim that he had better judgement on Iraq, 'the biggest fairy tale I've ever seen.,278 African Americans interpreted Clinton's remark as referring to Obama himself and not the Iraq issue. Hillary Clinton compounded the problem by stating, 'that while the civil rights movement needed the oratory of Martin Luther King, it also needed the experience of LBJ. ${ }^{279}$ Her comment seemed to cause offense in the African-American community. A January 2008 Gallup poll now showed Obama winning African American's by 57$32 \%$ over Clinton. ${ }^{280}$

Obama fought back from a popular vote loss in Nevada and defeat in New Hampshire to win the South Carolina primary by 28 points. Obama won nearly $56 \%$ compared to $26.5 \%$ for Clinton. Edwards could only manage $17.5 \%$ of the vote and was forced to pull out of the race. Obama received a timely boost in the lead up to the Super Tuesday primaries by receiving the key endorsement of Senator Edward Kennedy. Kennedy's endorsement of Obama was seen as the most influential endorsement given to date during the nominating contest. ${ }^{281}$

On Super Tuesday, 23 states held their nominating contest and Obama won 13 of those contests, to Clinton's 10. Obama's victories came from states such as Illinois, Alabama, Georgia, Colorado, Missouri and Minnesota. Clinton's victories came in large states such as Massachusetts, New Jersey, New York and California. On Super Tuesday Obama won 847 delegates, compared to 834 delegates for Clinton. ${ }^{282}$

In the weeks following the Super Tuesday nominating contests, Obama racked up an impressive number of victories. Obama swept the Nebraska, Washington, Maine and Hawaii caucuses in February and won the

\footnotetext{
${ }^{278}$ lbid, p. 115.

279 lbid.

${ }^{280}$ Ibid, p.116.

${ }^{281}$ MSNBC, 'Senator Kennedy Endorses Obama,' MSNBC 2008 Election News, http://www.msnbc.msn.com/id/22873162/ns/politics-decision 08/t/sen-kennedy-endorses-barackobama/, (Assessed 16 October 2010).

${ }^{282}$ Ceaser, Bush, Pine, Epic Journey - The 2008 Election and American Politics, p.118.
} 
'Potomac Primaries' on February 12. Obama also won the Louisiana and Wisconsin primaries in February. By this stage, Clinton's campaign was also in disarray with financial problems and Clinton had to lend her own money to the campaign. She needed to win big in the March 4 Primaries in Ohio and Texas to hold out any hope of winning the nomination. ${ }^{283}$

In the lead up to the March 4 contests, Clinton once again went on the offensive. Clinton's campaign provided journalists with news clips about Obama's ties to William Ayers, a former fugitive and a founding member of the radical Weather Underground. In Texas, Clinton also ran a television ad suggesting that she would be a safer pair of hands when dealing with national security:

'Its 3 a.m. and your children are safe and asleep. But there's a phone in the White House and its ringing. Who do you want answering the phone?,284

Clinton won the March 4, Ohio primary by winning 53.5\% to Obama's 44.8\% and Clinton also narrowly won the Texas primary 50.8\% - 47.4\% for Obama. Texas also held a caucus on the same day as the primary which gave Obama a victory and a majority of delegates out of Texas, Clinton had not received the boost that she needed. ${ }^{285}$

Despite being ahead in pledged delegates, Obama's campaign hit turbulence following the March 4 contests. Media featured excerpts of sermons by Obama's pastor, Jeremiah Wright. Wright's most incendiary comments were replayed over and over again on television:

'God bless America... No, no, no, God damn America, that's in the Bible for killing innocent people... God damn America for treating our citizens as less than human... God damn America for as long as she acts like she is God and she is supreme...,286

\footnotetext{
${ }^{283}$ Ibid, p.119.

${ }^{284}$ Ibid.

285 Ibid.

${ }^{286}$ Abdon M. Pallasch, "Obama Denounces Rhetoric But Stands Behind his Pastor," Chicago, SunTimes, March 16, 2008, http://www.suntimes.com/news/politics/obama/844447,CST-NWSwright15.article, (Assessed 16 October 2012).
} 
Obama was forced onto the defensive, but limited the damage by giving a well-received speech in Philadelphia. Obama said Wright's comments:

'Were not only wrong, but divisive, divisive at a time when we needed unity; racially charged at a time when we need to come together to solve a set of monumental problems. ${ }^{, 287}$

Clinton scored a double digit win in the Pennsylvania primary on April 22, but it was too little, too late. Obama won the North Carolina primary by a large margin on May 6. Clinton remained in the race for the rest of May, and on May 20, Obama's victory in the Oregon primary gave him a majority of pledged delegates. On June 3, after winning the Montana primary, Obama officially claimed the nomination and Clinton withdrew from the race. ${ }^{288}$

\section{The Race for President}

Arizona Senator John McCain won the Republican nomination, defeating a host of high profile candidate and thus the scene was set for the 2008 election. The 2008 campaign for president can be broken down into three distinct periods of time: from summer through to the end of the Democratic convention; after the close of the Democratic convention, through to mid-September and from mid-September with the onset of the global financial crisis, through to Election Day. ${ }^{289}$

During the early part of summer, Obama's focus was on unifying his party after a bruising primary campaign against Clinton. During the Democratic primaries, Clinton received approximately 18 million votes and Obama would need every one of those votes to be elected president. On Friday June 27, Obama joined Clinton in Unity, New Hampshire, for a campaign rally. ${ }^{290}$ The rally went a long way to heal the wounds that were created

\footnotetext{
287 Barack Obama, “A More Perfect Union," Philadelphia, Pennsylvania, March 18, 2008, http://www.barackobama.com/2008/03/18/remarks of Senator barack obama 53.php, (Assessed 16 October 2012).

${ }^{288}$ Ceaser, Bush, Pine, Epic Journey - The 2008 Election and American Politics, p.121.

289 lbid, p. 133.

290 lbid, p. 135.
} 
between both candidates during the primary season. Also in June, Obama was the first major candidate to opt out of public financing during a presidential campaign and opt instead to raise all his funds from private donors. Obama received widespread criticism from the media and political commentators for this decision. McCain accepted public financing and attacked Obama for his position, labelling him an 'opportunistic "flipflopper" after he had earlier agreed to accept public finance. ${ }^{291}$ With Obama continuing to fundraise, McCain was substantially out-spent during the campaign. In September alone, Obama raised \$150 million, compared to the $\$ 84.1$ million McCain received by accepting public finance. This disparity meant Obama was able to spend vast amounts of money on advertising and was able to purchase and air a 30-minute infomercial during prime time during the last week of the campaign. ${ }^{292}$

By far one of the most publicised events during the campaign was Obama's trip to the Middle East and Europe. Obama announced that his trip would be, 'an important opportunity to assess the situation in countries that are critical to American national security and to consult with some of our closest friends and allies about the common challenges we face. ${ }^{293}$ Obama's trip received huge media interest during the July visit. McCain attacked Obama as a 'celebrity phenomenon, akin to Paris Hilton or Britney Spears. ${ }^{294}$ McCain's message gained some traction and, by the beginning of August, McCain polled neck and neck with Obama in Gallup's Daily Tracking Poll. ${ }^{295}$

The first distinct period of the campaign culminated in the Democratic Convention in Colorado. Obama named Delaware Senator Joseph Biden Jr. as his running mate. The Democratic Convention was a success, with President Bill Clinton and Hillary Clinton giving rousing primetime speeches. Following the Democratic Convention, Obama was leading in

\footnotetext{
${ }^{291}$ Alan I. Abramowitz, 'How Obama Won the White House,' in Larry Sabato et al, The Year of Obama: How Barack Obama Won the White House, p.95.

${ }^{292}$ lbid.

${ }^{293}$ Ceaser, Bush, Pine, Epic Journey - The 2008 Election and American Politics, p.137.

294 lbid.

295 Ibid.
} 
the polls by six points and the Convention was expected to dominate the news for the coming days, until McCain acted, just some twelve hours after the convention. ${ }^{296}$

The second distinctive period of the campaign began just hours following the Democratic Convention, when McCain announced his running mate as Governor Sarah Palin of Alaska. Prior to her selection, Palin was a virtual unknown outside of Alaska, where she had an $80 \%$ approval rating as Governor. 'McCain was making a bold effort to show that despite all the glitter of the Obama campaign, he was the real thing. ${ }^{297}$ Palin's address to the Republican convention exceeded expectations and was well received by Conservatives. Following the convention, McCain took the lead in some polls. The share of Americans identifying themselves as Republicans rose from $26 \%$ just before the convention to $30 \%$ after it. Following the convention McCain took the unusual step of frequently appearing at rallies with Palin. They received huge crowds and Republican fundraising also improved. ${ }^{298}$ Palin was energising the party faithful and looked like being the game-changer McCain was after. McCain had a chance, but it would not last, as economic storm clouds were gathering.

The third distinct and decisive period began on September 14. During 2008, America faced a slowly deteriorating economy, combined with a spike in gasoline prices. The economy had surpassed the Iraq war as the number one issue and by July, approximately one third of voters cited the economy as the top issue. By Election Day that number would grow to $58 \%$, the highest level since the 1980 recession. ${ }^{299}$ On September 14 , the economy hit front and centre of the campaign as the Lehman Brothers bank filed for bankruptcy. The very next day McCain characterised the 'fundamentals of the economy as strong. ${ }^{300}$ McCain had to backtrack over this statement as the crisis deepened and polls confirmed that it was

\footnotetext{
296 lbid, p. 141.

297 lbid, p. 142.

298 lbid, p. 144.

299 lbid, p. 145.

300 lbid.
} 
Obama who was benefiting from the economic crisis. On September 24, after Obama and McCain agreed to sign a joint statement on dealing with the crisis, McCain abruptly announced he was suspending his campaign to return to Washington to work on passing a bailout for the financial industry. This announcement caught everyone by surprise. McCain made, 'himself hostage to the legislative process, where Democrats were not about to let him score a triumph and where many Republicans had some profound reservations about the plan. ${ }^{301}$

There was no quick vote on a bailout and Obama labelled McCain as 'erratic in a crisis,' after McCain threatened to pull out of the first debate in Oxford, Mississippi. ${ }^{302}$ Eventually bailout legislation was passed with both McCain and Obama supporting it. While McCain would participate in the first debate, the dye was cast and his campaign was in trouble. The economy was front and centre for the rest of the campaign and McCain's reaction to the crisis ensured he had lost all credibility on the issue. The economic statistics in the lead-up to polling day were depressing. In October, America's GDP had fallen by an estimated $0.3 \%$ during the third quarter, which was the worst result in more than a decade, and in November the Labor Department announced that the United States economy had shed more than 200,000 jobs during October. The official unemployment rate had risen to $6.5 \%$, its highest level in 14 years. ${ }^{303}$ The brief lead in the polls that McCain had experienced following the Republican Convention was gone and Obama established a clear lead in the national polls and key battle states. Between September 26 and Election Day, McCain never led Obama in a single national poll. ${ }^{304}$ Obama went into Election Day optimistic that he would become the $44^{\text {th }}$ President of the United States.

\footnotetext{
${ }^{301}$ Ibid, p.146.

${ }^{302}$ Ibid, p.147.

${ }^{303}$ Alan I. Abramowitz, 'How Obama Won the White House,' in Larry Sabato et al, The Year of Obama: How Barack Obama Won the White House, p.101. ${ }^{304}$ Ibid.
} 


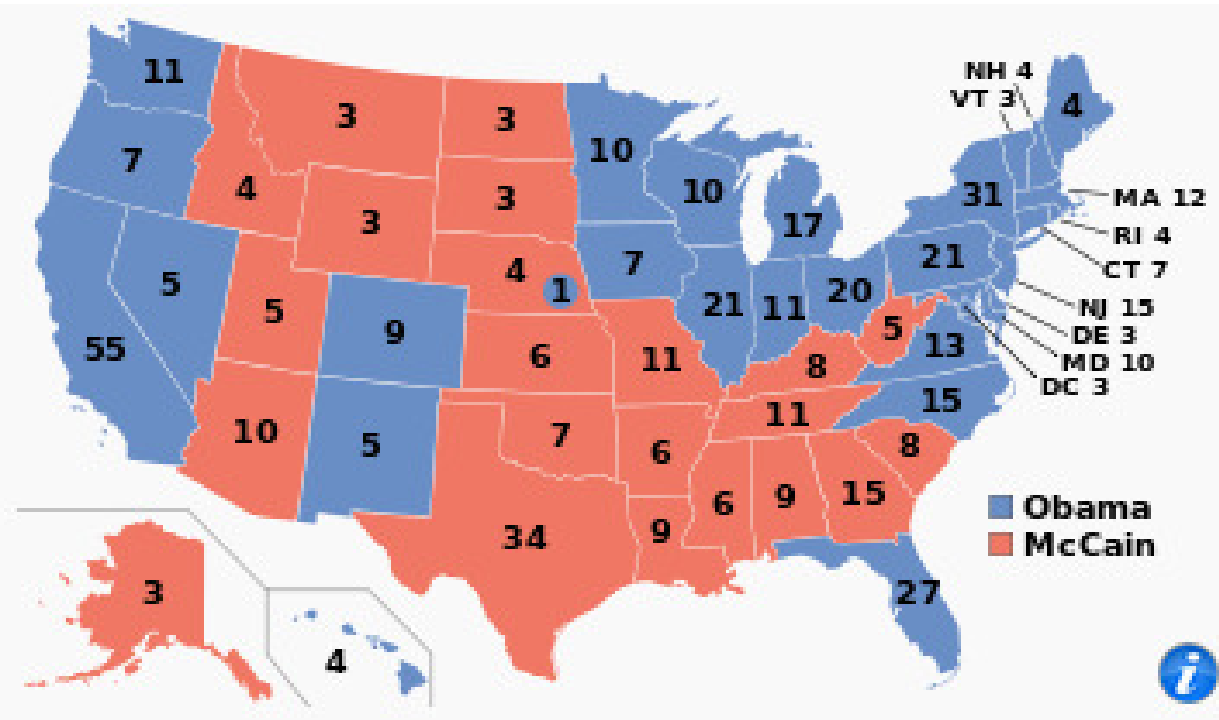

Figure 2: 2008 Presidential Election Results ${ }^{305}$

On election day, Obama comfortably won the White House by a margin of more than 9 million votes over McCain, with $53 \%$ of the vote, compared to 45.7\% for McCain. Obama won 365 electoral votes, compared to 173 electoral votes for McCain. Obama won nine states that Bush carried in 2004: Florida, Ohio, New Mexico, lowa, Virginia, North Carolina, Colorado, Nevada and Indiana. Obama also won one electoral vote in Nebraska, after winning the first congressional district. The result was historic, as no Democrat had won Virginia or Indiana since 1964 or North Carolina since 1976. Obama was the first Democratic candidate since Carter in 1976 to win a majority of the popular vote and was the largest for any presidential candidate since 1988 . The Democrats also made gains in Congress by picking up seven seats in the Senate and 20 seats in the House. ${ }^{306}$ The 2008 election also brought increased turnout with just over 131 million people voting in 2008 or close to $62 \%$ of eligible voters. This was the highest turnout since 1968. The increased turnout rate, as expected, was caused by an upturn in African American voting, as well as a rise in participation among young voters. ${ }^{307}$ Obama, with the support of Hispanics, African Americans, women and young voters had become a new electoral coalition that replaced the coalition created in 1980 by

\footnotetext{
${ }^{305}$ US Election Atlas, '2008 Presidential Election Results', http://uselectionatlas.org/RESULTS/, (4 October 2012).

${ }^{306}$ Alan I. Abramowitz, 'How Obama Won the White House,' in Larry Sabato et al, The Year of Obama: How Barack Obama Won the White House, p.105.

${ }^{307}$ Ceaser, Bush, Pine, Epic Journey - The 2008 Election and American Politics, p.152.
} 
Reagan Obama had harnessed a new electoral coalition and now was the time to transform America.

\section{4 and its Morning Again in America}

'I will not make age an issue of this campaign. I am not going to exploit, for political purposes, my opponent's youth and inexperience. ${ }^{308}$

Ronald Reagan: 1984 Presidential Debate

Reagan went onto win a landslide victory in 1984, crushing Democrat hopeful Walter Mondale. Reagan ran a largely positive campaign focussing on the economic recovery. The campaign slogan, 'Morning again in America' is one of the more memorable. While Reagan was unchallenged for the Republican nomination, former Vice-President Walter Mondale ultimately clinched the Democratic nomination against a strong challenge from Senator Gary Hart.

\section{The Race for President}

As the general election campaign began, things were looking rosy for Reagan. By the second quarter of 1984, the economic boom was taking shape with the economy growing at $7.4 \%$ with inflation sitting at $3.2 \%$. As of July 1 , the United States economy had experienced the strongest four quarters of growth in a generation. ${ }^{309}$ At the same time, political polls showed Reagan ahead of Mondale by up to 20 points. However, the race would tighten, and on October 7 in Louisville, Kentucky, Reagan took a stumble in the first presidential debate. Reagan was off his game and appeared distant and confused throughout the debate. The media and Mondale went on the attack, arguing that Reagan's age had caught up with him. ${ }^{310}$

\footnotetext{
${ }^{308}$ Commission on Presidential Debates, 'October 21, 1984 Debate Transcript: The Reagan-Mondale Presidential Debate', 2009, http://www.debates.org/index.php?page=october-21-1984-debatetranscript.html, (6 March 2012).

${ }^{309}$ Steven F. Hayward, The Age of Reagan: The Conservative Counterrevolution 1980-1989, p.375. ${ }^{310}$ Ibid, p.377.
} 
Following the first debate the polls narrowed and by the second debate in Kansas City, Reagan would lead Mondale by $11 \%$. Reagan won the second debate with a much improved performance. The key moment occurred 30 minutes into the debate when the moderator asked Reagan a question about how he would function for days on very little sleep. The question focussed on the biggest doubt voters had on giving Reagan a second term. Reagan answered calmly and stated,

'Not at all Mr Trewhill and I want you to know that also I will not make age an issue of this campaign. I am not going to exploit for political purposes, my opponent's youth and inexperience. ${ }^{311}$

The crowd erupted with laughter and, as David Broder wrote the next day in the Washington Post, 'it may have been that the biggest barrier to Reagan's re-election was swept away in that moment. ${ }^{312}$ Following the debate Reagan led by $17 \%$ in the polls and he held a lead of at least $15 \%$ or better throughout the remainder of the game. ${ }^{313}$

During the last weeks of the campaign, Reagan attempted to reach across the political aisle and attract Democratic voters to the Republican cause:

'To all those Democrats, and I hope there are many here, who have been loyal to the party of FDR and Harry Truman and JFK, people who believe in protecting the interests of working people, who are not ashamed of America's standing for freedom in the world - we say to you: Join Us. Come Walk with us down that new path of hope and opportunity. I was a Democrat most of my adult life. I didn't leave my party and we're not suggesting you leave them. I am telling you that what I felt was that the leadership of the Democratic Party left me and millions of patriotic Democrats in this country who believed in freedom. ${ }^{314}$

Reagan won58.8\% of the popular vote and 525 electoral votes, compared to just $41 \%$ of the popular vote and 13 electoral votes for Walter Mondale. Reagan's victory rivalled the four other landslides of the century: 1920,

\footnotetext{
${ }^{311}$ Lou Cannon, President Reagan: The Role of a Lifetime, p.487.

${ }^{312}$ David S Broder, "Encounter Leaves Reagan On Course," The Washington Post, October 22, 1984, p. 1 .

${ }^{313}$ Lou Cannon, President Reagan: The Role of a Lifetime, p.487.

${ }^{314}$ Steven F. Hayward, The Age of Reagan: The Conservative Counterrevolution 1980-1989, p. 378379 .
} 
1936, 1964 and 1972 and his 49 state sweep equalled Nixon's victory in 1972. A Time Magazine article described:

'The campaign was dominated by four Ps: Prosperity, Peace, Patriotism, and Personality. In 1980, voters had elected Reagan largely to rectify the country's decade long economic problems, and four years later, the majority of voters felt that he had succeeded. Reagan had delivered on his promise of tax cuts, the economy was expanding, unemployment was low, and prices had stabilised. Reagan had rebuilt pride in the country, enhanced its military strength, and kept America out of war. The magnitude of Reagan's victory established him as the most popular president since Dwight D. Eisenhower. ${ }^{315}$

Despite Reagan's sweeping victory, the Republican's only picked up fourteen seats in the House, and lost ground in the Senate. In this respect, Reagan's landslide was like Nixon's landslide of 1972, rather than the landslides of FDR in 1936 and LBJ in 1964, both of which translated into significant party gains that enabled major policy changes in their aftermath. ${ }^{316}$

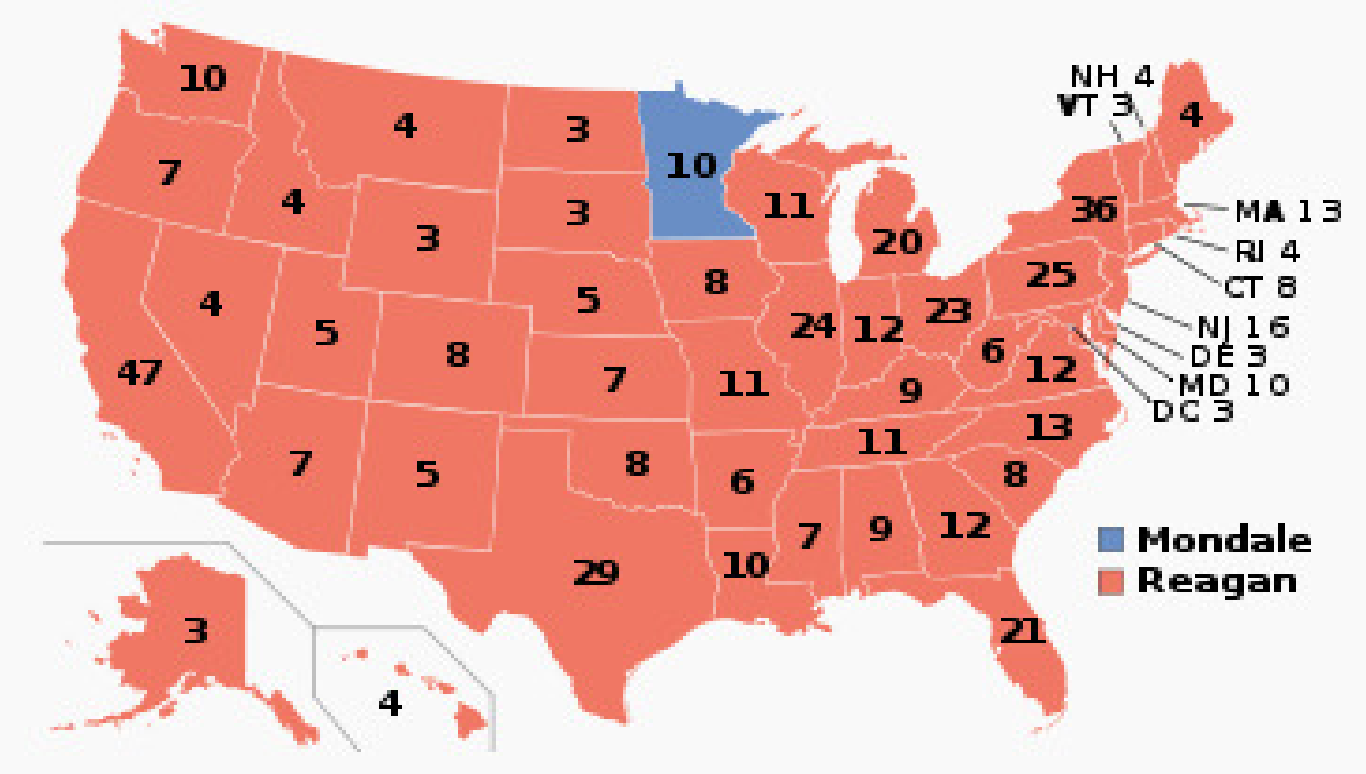

Figure 3: 1984 Presidential Election Results ${ }^{317}$

Overall, Reagan received the largest electoral-vote landslide in United States history. Reagan gained a majority in every region of the country, in every age-group, in cities, in towns, suburbs, and rural areas and every

\footnotetext{
${ }^{315}$ Yanek Mieczkowski, The Routledge Historical Atlas of Presidential Elections, p.136.

${ }^{316}$ Steven F. Hayward, The Age of Reagan: The Conservative Counterrevolution 1980-1989, p.338.

317 US Election Atlas, '1984 Presidential Election Results', http://uselectionatlas.org/RESULTS/, (4 October 2012).
} 
occupational category except the unemployed. Reagan won $61 \%$ of independents and a quarter of registered Democrats. He won $62 \%$ of male voters and $54 \%$ of female voters, despite Mondale choosing Geraldine Ferraro as his running mate. ${ }^{318}$

\section{2 and the new Democratic Coalition}

'I believe we can keep the promise of our founding, the idea that if you're willing to work hard, it doesn't matter who you are or where you come from or what you look like or who you love. It doesn't matter whether you're black or white or Hispanic or Asian or Native American or young or old or sick or poor, abled, disabled, gay or straight. You can make it in America if you're willing to try. ${ }^{319}$

President Barack Obama, 2012 Election Night Address

Obama suffered many setbacks during the first term which led Republicans to believe they could win the White House. Obama inherited an economy on the brink of collapse and a nation fighting two wars. While Obama won the Democratic Nomination unopposed, several candidates challenged for the Republican nomination. Ultimately former Massachusetts Governor Mitt Romney won the nomination, largely due to his superior organisation and fundraising efforts, and because he was seen by the Republican primary voters as the candidate most likely to defeat President Obama.

The Race for President

Obama started the general election marginally ahead of Romney in the polls and that continued through much of the summer. Romney's campaign was plagued with mistakes during the summer months. One such mistake occurred while Romney was in London during the lead-up to

\footnotetext{
${ }^{318}$ Lou Cannon, President Reagan: The Role of a Lifetime, p.434.

${ }^{319}$ Barack Obama, 'Remarks by the President on Election Night,' 7 November 2012, www.whitehouse.govt/the-press-office/2012/11/07/remarks-president-election-night, (Assessed 9.11.2012).
} 
the 2012 Olympic Games. Just 48 hours before the Opening Ceremony, Romney caused a diplomatic incident following an interview with NBC Nightly News. Romney said:

'You know, it's hard to know just how well it will turnout. There are a few things that were disconcerting. The stories about the private security firm not having enough people, the supposed strike of the immigration and customs officials - that obviously is not something which is encouraging. ${ }^{, 320}$

Romney was the CEO of the Salt Lake City Winter Olympics Organising Committee that conducted a successful games in 2002. Following this outburst from Romney the British media pounced and drew British Prime Minister David Cameron into the debate:

'I think we will show the whole world not just that we come together as a United Kingdom, but also we're extremely good at welcoming people from across the world. ${ }^{321}$

London Mayor Boris Johnson also hit out at Romney on the eve of the Olympic Games in remarks to a London crowd:

'There's a guy called Mitt Romney who wants to know whether we're ready. Are we ready? We are ready! ${ }^{322}$

Romney also visited Israel and Poland on the tour that aimed to boost his foreign affairs profile. Ultimately the trip would create more questions than answers about Romney's suitability to be president.

On August 11, Romney announced his decision that the Wisconsin Congressman, Paul Ryan would be his Vice-Presidential running mate. The Republican Convention was a lacklustre affair, with a rambling Clint Eastwood speaking to an empty chair that represented President Obama, detracting from Romney's acceptance speech. The Democratic Convention was seen largely as a success with a stirring speech delivered by President Bill Clinton, who eloquently explained why Obama should be

\footnotetext{
${ }^{320} \mathrm{Jim}$ Acosta, 'Romney's Olympics False Start', 26 July 2012, www.politicalticker.blogs.cnn.com/2012/07/26/romneys-olympics-false-start, (Assessed 14 November 2012). ${ }^{321}$ Ibid.

322 BBC, 'Boris Johnson chives Mitt Romney over London Olympics,' 27 July 2012, www.bbc.co.uk/news/world-us-canada-19007127, (Assessed 16 November 2012).
} 
given a second term, while repudiating the Republican agenda. A CNNORC poll conducted following the Democratic Convention showed Obama with a $52 \%-46 \%$ lead over Romney, after they were tied at $48 \%$ in the same poll the previous week. ${ }^{323}$

Romney came under a stinging attack after a leaked recording from May was released, which had Romney saying:

'There are 47 percent who are with him, who are dependent on government, who believe that they are the victims, who believe the government has a responsibility to care for them, who believe that they are entitled to health care, to food, to housing, you name it, that's an entitlement and they will vote for this president no matter what. ${ }^{, 324}$

The $47 \%$ tape, alongside his foreign trip and the disappointing Republican Convention led many to believe Romney was out of touch with America. CNN analyst John King argued:

'They say timing is everything in politics. The timing of the release of this tape is terrible for Romney. He needs to be making his case about tomorrow's economy, not trying to explain away thing he said months ago. While a healthy debate about government programs and priorities is always useful, such sweeping generalisations as those used by Romney are after a path into political

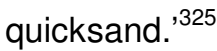

Romney was running out of time to turn the race around as the contest was looking increasingly likely to see Obama re-elected. The presidential debates would be Romney's final chance to shake the race up.

By the time of the first debate, Obama had built up a solid lead in the polls, but suffered badly in the first debate. The debate focussed on domestic issues and was held on October 3, at the University of Denver in Colorado. Romney came out firing and caught Obama by surprise.

Obama put in a lacklustre performance against Romney who appeared

\footnotetext{
${ }^{323}$ CNN, 'Romney doesn't back away from message caught on secret tape', 19 September 2012 , www.edition.cnn.com/2012/69/18/politics/campaign-wrap/index.html, (Assessed 14 November 2012). 324 John King, 'For Romney, how bad is this?' 19 September 2012 , www.edition.cnn.com/2012/09/18/politics/king-romney-how-bad-index.html, (Assessed 14 November 2012) ${ }^{205}$ Ibid.
} 
more confident and strong throughout. Romney challenged Obama over healthcare reforms, his management of the economy and on taxes. Romney labelled the president's approach as 'trickle-down government' and also accused Obama of spending too much time concentrating on passing his health care plan at the expense of creating jobs. A postdebate Gallup poll recorded a record victory for Romney by $52 \%$ over Obama. $^{326}$ Even Democratic commentators felt Romney had won. For instance, Democratic strategist Donna Brazile stated:

'Mitt Romney did a lot of good. He came to play, came to pivot. Tonight Mitt Romney was a little more aggressive than the President. ${ }^{327}$

Following the debate, the polls started to close and it was 'game on'. Overall, in the three presidential debates, Romney's strong start changed the equation of the race and sparked a revitalised response from Obama. In the other two debates, polls indicated that Obama was judged to have won, albeit marginally. The focus on the debates showed that presidential debates do matter and that they are an important mechanism for the underdog to strike and shake up the race. ${ }^{328}$

Just a week out from Election Day, Obama had recovered to hold a steady but narrow lead in several of the crucial swing states when Hurricane Sandy ripped up the Eastern Seaboard and caused both campaigns to cancel campaign events for 48 hours. Obama had the platform to look presidential and Romney was shoved to the side-lines. Despite the death and destruction that Hurricane Sandy inflicted on the Eastern Seaboard, Americans judged that Obama had done a good job in responding to it. Obama travelled to New Jersey and toured the most affected communities with Republican Governor and staunch opponent of Obama, Chris Christie. Christie was hugely complimentary of Obama's response to the hurricane and stated,

\footnotetext{
${ }^{326}$ Russell Goldman, 'Romney comes out swinging,' 2 October 2012, www.abcnews.go.com/politics/OTUS/mitt-romney-siwinging-presidential-debate, (Assessed 14 November 2012).

327 Ibid.

${ }^{328}$ Tom Cohen, 'It all shows: debates do matter in 2012,' 23 October 2012, www.edition.cnn.com/2012/10/23/politics/debates-do-matter/index.html, (Assessed 14 November 2012).
} 
'I cannot thank the president enough for his personal concern and compassion for our state. It's been a great working relationship., ${ }^{329}$

The image of bipartisanship was exactly what the Obama campaign needed in the final week leading up to Election Day. Obama was also boosted by the last minute endorsement of New York Mayor and independent Michael Bloomberg, as well as the endorsement of Colin Powell, who had earlier endorsed him in $2008 .{ }^{330}$ As Election Day loomed many polls in the swing states were indicating a slight lead for Obama, but within the margin of error. Many commentators were saying the election was too close to call.

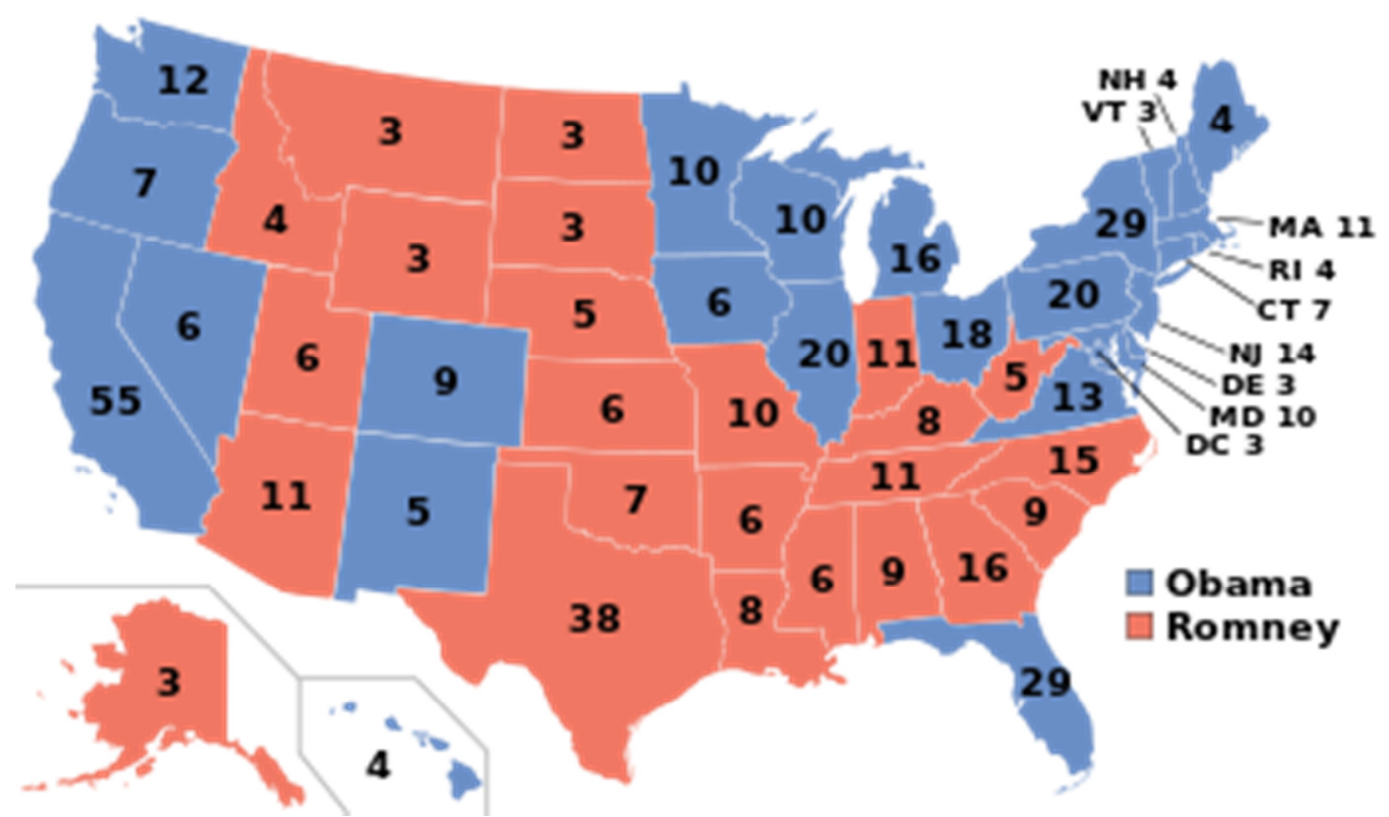

Figure 4: 2012 Presidential Election Results ${ }^{331}$

On Election Day Obama won re-election with $51 \%$ of the popular vote and 332 electoral votes, compared to $47.2 \%$ and 206 electoral votes for Romney. Obama's victory is testament to a changing America. The president won a second term in the face of a weak economy by reassembling the bulk of his 2008 coalition: African Americans, Hispanics,

\footnotetext{
${ }^{329}$ Kate Zernike, 'One Result of Hurricane: Bipartisanship Flows,' 31 October 2012 , www.nytimes.com/2012/11/01/nyregion/in-stunning-about-face-chrischristie.htm, (Assessed 14 November 2012). ${ }^{330}$ Ibid.

${ }^{331}$ US Election Atlas, '2012 Presidential Election Results', http://uselectionatlas.org/RESULTS/, (16 November 2012).
} 
younger voters and women. ${ }^{332} \mathrm{~A}$ new electoral coalition had been created which had replaced the dominant coalition created by Reagan in the 1980's. Obama's re-election is the first time since 1944 and FDR's reelection that a Democratic candidate has succeeded in winning a majority of the popular vote in two consecutive elections.

\section{Reagan and Obama: Electoral Coalitions}

While Chapter Six of this thesis will specifically analyse Reagan's reconstruction and analyse the prospects of an Obama reconstruction, no one can doubt that both were elected by new coalitions and that the 1980 and 2008 elections were realignment elections. As already stated, one of Skowronek's criteria for a reconstructive presidency argues that politics are transformed when new interests secure a firm grip on power. ${ }^{333}$ According to Skowronek, the president who forms an enduring governing coalition has more in common with the founder of earlier coalitions than with other presidents of his own era:

'Want to understand FDR? Don't compare him to Truman or Eisenhower, urged Skowronek - instead, compare him to Andrew Jackson. Want to make sense of Jimmy Carter? Look to Franklin Pierce, who like Carter served in a governing coalition's rapidly fragmenting final days. ${ }^{334}$

This is precisely what Reagan and Obama had achieved and hence why they have been compared.

\section{The Reagan Coalition}

Reagan's 1980 election landslide brought about a collapse of the New Deal coalition. Several key demographics switched support from the Democrats to Reagan and the Republicans in 1980. Blue-collar workers, who in 1976 supported Jimmy Carter against Republican Gerald Ford by

\footnotetext{
${ }^{332}$ Alan Silverleib , 'Analysis: Obama's new Democratic majority,' November 72012 , www.edition.cnn.com/2012/11/07/politics/exit-polls-analysis/index.html, (Assessed 9 November 2012).

${ }^{333}$ Stephen Skowronek, Presidential Leadership in Political Time: Reprise and Reappraisal, p.171.

334 Ibid.
} 
a 3-2 margin, switched their support to Reagan. According to exit poll results in 1980, Reagan marginally won Blue Collar voters by $1 \%$. What was even more surprising was the fact that union families who supported Carter in 1976 by a whopping $27 \%$ only supported Carter by $5 \%$. Reagan would actually carry the white union vote in 1980 after Carter carried the vote in 1976. Finally Blue-collar workers who believed the economy would be worse in a year supported Reagan by a 2-1 ratio. ${ }^{335}$

The 1980 election also brought about the term Reagan Democrat. Reagan Democrats are traditionally white working class voters from the industrial north who switched their support from the Democrats to Reagan in the 1980s. Pollster Stanley Greenberg has spent time analysing voting patterns in the largely white labor unionised auto workers in Macomb County in Michigan. In 1960 the county voted 63\% for John F Kennedy, but in 1980 the county swung behind Reagan, where he won $66 \%$ of the vote against Carter. ${ }^{336}$ Greenberg concluded:

\begin{abstract}
'Reagan Democrats" no longer saw Democrats as champions of their working class aspirations, but instead saw them as working primarily for the benefit of others: the very poor, feminists, the unemployed, African Americans, Latinos, and other groups. In addition, Reagan Democrats enjoyed gains during the period of economic prosperity that coincided with the Reagan administration following the "malaise" of the Carter administration. They also supported Reagan's strong stance on national security and opposed the 1980s Democratic Party on such issues as pornography, crime, and high taxes. ${ }^{, 337}$
\end{abstract}

In 1980, Reagan won $27 \%$ of those who identified themselves Democrats. This is a substantial number and hence the birth of Reagan Democrats. Alongside the Reagan Democrats, Evangelical Christians came together in 1980 and even more so in 1984 to support Reagan and the Republicans. Carters vote amongst Evangelical Christians fell by about one-fourth from 1976-1980. Reagan's pollster, Richard Wirthlin argued that his gains among evangelicals gave him victories in North Carolina,

\footnotetext{
${ }^{335}$ Andrew E Busch, Reagan's Victory: The Presidential Election of 1980 and the rise of the right,p.127

${ }^{336}$ Stanley B. Greenberg, Middle Class Dreams: The Politics and Power of the New American Majority, (New Haven: Yale University Press, 1996), p.25.

${ }^{337}$ Ibid.
} 
Kentucky, Tennessee, Alabama and Mississippi. By $198478 \%$ of bornagain Christians voted for Reagan. ${ }^{338}$ Also shifting support from Carter to Reagan were Catholic voters. In 1976 Carter won the Catholic vote by $15 \%$ over Ford. In 1980 Reagan carried the Catholic vote by a surprising $7 \%$, a big swing from $1976 .{ }^{339}$ The Republicans, in every election since 1980 had won the Evangelical Christian vote.

The 1980 election also gave birth to the gender gap. In 1976, Carter won the male vote and lost the female vote lost the male vote to Reagan by a wide margin. Reagan won $55 \%$ of the male vote, compared to just $38 \%$ for Carter. ${ }^{340}$ The gender gap would continue until today, where Republican candidates score better with males and Democratic candidates scoring better with female voters.

Overall, the Republican Party won elections during the 1980s because Reagan defined it as a party of liberty and virtue. Reagan helped frame the Republicans as a party of taxpayers and religious evangelicals, with its base in the South and out West. Reagan's tough stance on foreign policy, his push for traditional values and his sunny disposition found favour with many blue-collar workers, who are known today as the 'Reagan Democrats'. ${ }^{341}$ Finally political analyst William Schneider commented:

'He (Reagan) was FDR's true successor. He destroyed the New Deal coalition and laid the groundwork for the Republicans to become the majority party for the first time in half a century. ${ }^{342}$

Reagan's coalition held together for much of the next 28 years, with George H.W Bush and his son, George W. Bush winning the presidency on the back of the coalition that elected and re-elected Reagan's in 1980 and 1984. From 1980-2008, a Republican would be in the White House for 20 of the 28 years.

\footnotetext{
${ }^{338}$ Andrew E Busch, Reagan's Victory: The Presidential Election of 1980 and the rise of the right, p.128.

339 Ibid, 127.

340 Ibid, p.128.

${ }^{341}$ Dinesh D'Souza, Ronald Reagan: How an Ordinary Man Became an Extraordinary Leader, p 253.

342 Ibid.
} 
In early 1980 , the eve of the Reagan reconstruction, $51 \%$ of voters identified themselves as Democrats, 30\% were Republicans and $19 \%$ identified themselves as independents. By 1994, at the mid-point of the Reagan era, the number of partisan identifiers was nearly equal, with $34 \%$ identifying themselves as Democrats and 31\% labelling themselves Republicans. But by 2008, on the eve of Obama's election, the number of Republican identifiers stood at $36 \%$, while the number Democrat identifiers had soared to $51 \%$, back to 1980 levels. ${ }^{343}$ But this time, the Democratic coalition was more diverse than it was in 1980.

Obama's electoral coalition reflects the increasing diversity of America. In $2008,61 \%$ of Obama's supporters were white voters, $23 \%$ African American's and $11 \%$ Hispanic. This is in contrast to John McCain, whose support was made up of $90 \%$ white voters. In $2008,74 \%$ of the electorate were white voters, down from $77 \%$ in 2004 . McCain won $55 \%$ of the white vote. In contrast, African American's made up 13\% of the electorate, up from 11\% in 2004 and Obama won 95\% of that vote. In 2004 Hispanic voters made up $8 \%$ of the electorate and split $60-40 \%$ for John Kerry over George W. Bush. In 2008, Hispanic voters made up $9 \%$ of the electorate and Obama won $67 \%$ of the vote. ${ }^{344}$ Obama convincingly won the women's vote, which made up $53 \%$ of the electorate, winning $56 \%$, to just $43 \%$ for McCain. Obama also marginally won the male vote $49-48 \%$. What is more dramatic is that Obama narrowed the white male vote that made up $36 \%$ of the electorate to $16 \%$, down from the $25 \%$ disparity that existed in 2004. No Democratic candidate has received more than $38 \%$ of the white male vote since Carter won $38 \%$ in $1976 .{ }^{345}$

\footnotetext{
${ }^{343}$ John Kenneth White, Barack Obama's America: How New Conceptions of Race, Family, and Religion ended the Reagan Era, (Michigan, University of Michigan Press, 2009), p.221.

${ }^{344}$ Chuck Todd and Sheldon Gawiser, How Barack Obama Won: A State By State Guide to the Historic 2008 Presidential Election, (New York: Random House, 2009), p.29.

${ }^{345} \mathrm{Ibid}$, p.32-33.
} 
In the 2012 election, Obama's coalition held firm. African American voters made up $13 \%$ of the electorate and Obama won $93 \%$ of the vote. The Hispanic vote made up $10 \%$ of the electorate, up from $9 \%$ in 2008 , with Obama winning a record $71 \%$ of the vote. Women made up $53 \%$ of the electorate and Obama won 55\% of the vote. Finally the 18-29 year old age group made up $19 \%$ of the electorate and Obama won $60 \%$ of the vote. On the other hand he only won $45 \%$ of the male vote and only $39 \%$ of the white electorate, made up $72 \%$ of the electorate. ${ }^{346}$ Compared to Reagan, Obama was elected with a new coalition rather than siphoning off a core demographic, the so-called Reagan Democrats. George Bush in 1988 was elected with the same coalition that elected Reagan in 1980 and was made of the coming together of the religious right and Reagan Democrats. If Obama's reconstruction is to come to fruition, then the same diverse coalition will need to solidify and elect a Democrat as president in 2016.

Following the 2012 election, much has been written about the coalition that re-elected Obama. Bob Moser of The American Prospect commented:

'Obama did it by assuming the most diverse political coalition in the nation's history - huge majorities of young people, African Americans, Latinos, Asian Americans, women and highly educated whites. That is a coalition of the future. It is also a coalition that is far and away more liberal, in terms of both economic and social views, than the supporters cobbled together by any Democratic president in history. FDR depended on conservative whites from the South for his victories; so did Truman, Kennedy, and, to a lesser extent Johnson, Carter, and Clinton. Going forward, future Democratic presidents will not either. ${ }^{347}$

By purely looking at demographics, the coalition that elected Obama is the coalition that will elect the president for many years to come. The challenge for the Democratic Party is to keep that coalition together. The

\footnotetext{
${ }^{346}$ CNN, '2012 Exit Poll Results', 7 November 2012, http://edition.cnn.com/election/2012/results/race/president, (Assessed 17 November 2012).

${ }^{347}$ Bob Moser, 'Obama wins the future,' in The American Prospect, 7 November 2012, www.propsect.org/article/obama-wins-future, (Assessed 9 November 2012).
} 
challenge for the Republicans is to adapt their platform to attract these diverse voters.

Obama himself talked about this new coalition on the night of the 2008 New Hampshire Primary:

'There is something happening when people vote not just for the party they belong to but the hopes they hold in common - that whether we are rich or poor, black or white, Latino or Asian; whether we hail from lowa or New Hampshire, Nevada or South Carolina, we are ready to take this country in a fundamentally new direction. That is what's happening in America right now. Change is what's happening in America. You can be the new majority who can lead this nation out of a long political darkness... ${ }^{348}$

Even before the 2008 New Hampshire primary, Obama's campaign was launched in the mould of Abraham Lincoln. With Obama launching his campaign in Springfield, Illinois in late 2007, he aimed to emulate Lincoln. Like Obama, Lincoln had been an unlikely outsider seeking the presidency, driven by the compelling power of a transformative vision. Obama was quick to remind the American people that it had been some time since a 'president had risen to the standard set by the great political leaders in American history. 349

Democratic strategist James Carville has written about the emerging Democratic Coalition in his book 40 More Years: How the Democrats will Rule the Next Generation:

'American presidential politics is generally not a back-and-forth enterprise. There are eras in which one party dominates. Today, a Democratic majority is emerging, and it's my hypothesis, that this majority will guarantee the Democrats remain in power for the next forty years. ${ }^{350}$

Carville went on to argue that Obama created a new Democratic party that is stronger than ever. Obama 'brought new people in all across the

\footnotetext{
${ }^{348}$ Barack Obama, 'Remarks of Senator Barack Obama: Night of the New Hampshire Primary,' in Mary Frances Berry and Josh Gottheimer, Power in Words: The stories behind Barack Obama's Speeches, From the State House to the White House, p.147.

${ }^{349}$ Stephen Skowronek, Presidential Leadership in Political Time: Reprise and Reappraisal, p.168.

350 James Carville, 40 More Years: How the Democrats will Rule the Next Generation, (New York: Simon and Schuster, 2009), p. vii.
} 
country and in 2008 those people were donating, registering, and voting alongside the existing base of Democratic voters. ${ }^{351}$ Carville states that the current Republican Party is based and has always been based upon whites and, in particular, white males. The Republican Party today tends to be a regional party based in the South, heavily dependent upon disappearing demographics. Following the 2008 election, nearly half of all Republican-held seats in Congress were in the south. ${ }^{352}$ Carville also argues that the Democratic majority started to emerge in 2004 and with Obama's victory in 2008 and subsequent re-election in 2012 the Democrats are well placed to win into the future, just as the Republicans held office for much of the period from 1968-1992. ${ }^{353}$

Looking ahead to 2016 and behind, the onus is certainly on the Republican Party to appeal to ethnic minorities who are only going to grow in numbers. Analysis following the 2012 election points to the fact that Obama performed more strongly in the south than any other Democratic nominee for three decades, due to a growing ethnic minority. Obama scored victories in Virginia and Florida and narrowly lost in North Carolina. Obama also polled well in Georgia and won $44 \%$ of the vote in South Carolina and just less than that in Mississippi - despite no major campaign efforts in those states. In every southern state except Louisiana, the population of African Americans grew substantially faster than whites in the past decade. For example in Florida, the share of votes cast by whites fell to $66 \%$ in 2012 , down from $73 \%$ in 2000 . In Georgia the number of white voters declined while African American registration increased nearly $6 \%$ and Hispanic voters grew by $36 \%{ }^{354}$ This poses problems for the Republicans' long term strategy and Atlanta Mayor Kasim Reed argues that, because of changing demographics: 
'Georgia is an achievable target for Democrats in 2016. What you're going to see is the Democratic Party making a drive through the geography from Virginia to Florida. ${ }^{355}$

While the task for the Democratic Party will be harder in 2016 without Obama on the ticket, the Republicans will not be able to bank on the "Southern strategy" of the Nixon and Reagan eras to win back the White House. David Bositis from the Joint Centre for Political and Economic Studies argues:

'I do think that the era that began with Ronald Reagan where there was a conservative dominance powered by conservative voters and Southern whites. That era is over. Any candidate that wants to run a campaign [now] only at whites is going to lose. ${ }^{356}$

Overall, Obama has achieved what Reagan managed to achieve: the creation of a new governing coalition. The new coalition fulfils for Obama, one of Skowronek's criteria for a reconstructive presidency - concrete evidence that the era of Reagan is over and the era of Obama has begun.

\footnotetext{
355 Ibid.

${ }^{356}$ Halimah Abdullah, 'With their big political win, the new American electorate has arrived', November 10 2012, CNN, http://edition.cnn.com/2012/11/09/politics/demographic-politicalpower/index.html?iref=allsearch, (Assessed 11 November 2012).
} 


\section{Chapter Five: The Presidents as leaders - Reagan and Obama in office}

\section{Ronald Reagan and the Shining City on the Hill}

'I've spoken of the shining city all my political life, but I don't know if I ever quite communicated what I saw when I said it. But in my mind it was a tall proud city built on rocks stronger than oceans, wind-swept, God-blessed, and teeming with people of all kinds living in harmony and peace, a city with free ports that hummed with commerce and creativity, and if there had to be city walls, the walls had doors and the doors were open to anyone with the will and the heart to get here. That's how I saw it, and see it still. ${ }^{357}$

Ronald Reagan: Farewell address to the Nation, 1989

Reagan's first term: 1981-1985

Chapter Four analysed the 1980 presidential election. It is enough to say that Reagan won it in a landslide and on the $20^{\text {th }}$ of January 1981 was sworn in as the fortieth president of the United States. Reagan entered the White House with the American economy in the doldrums. His inaugural speech would argue for a new America, articulating his belief that there was too much government intervention in the lives of Americans.

'In this present crisis, government is not the solution to our problem; government is the problem. From time to time we've been tempted to believe that society has become too complex to be managed by self-rule, that government by an elite group is superior to government for, by, and of the people. Well, if no one among us is capable of governing himself, then who among us has the capacity to govern someone else? All of us together, in and out of government, must bear the burden.

\footnotetext{
${ }^{357}$ Ronald Reagan, 'Farewell Address to the Nation' in Speaking My Mind: Ronald Reagan Selected
} Speeches, (London: Century Hutchison Ltd, 1990), p.417-418. 
The solutions we seek must be equitable, with no one group singled out to pay a higher price. ${ }^{358}$

In the minutes following Reagan's inauguration, the 52 American hostages that had been held in Iran for 444 days, were released. Reagan set to work immediately following his inauguration to roll out his platform, but his presidency was halted by an assassination attempt. On March $30^{\text {th }}$ 1981, Reagan was shot by John Hinckley Jr. outside the Washington Hilton hotel. Reagan was seriously injured when the bullet missed his heart and lodged in his lung, causing it to collapse. Reagan quickly recovered from his injuries and set about transforming the American economy. ${ }^{359}$

The centre piece of Reagan's agenda argued for an across the board tax cut, and on July 291981 Congress passed Reagan's tax bill: The Economic Recovery Tax Act 1981. Reagan's original plan called for a $30 \%$ tax cut, but in the end a $25 \%$ across the board tax cut was passed. Reagan argued that by enacting the tax cut, America would begin seeing signs of prosperity by the end of 1981 . The Act aimed to encourage economic growth through reductions in individual income tax rates, the expensing of depreciable property, incentives for small businesses, and incentives for savings. ${ }^{360}$ By the end of 1981, unemployment reached a six year high and Reagan was forced to concede that the nation was in a recession. Reagan sent his 1983 budget to Congress with big budget cuts across the board, except on defence. While total cuts to the budget were just under $\$ 200$ billion dollars, there was a predicted budget deficit of $\$ 91.5$ billion for 1983, despite Reagan's promise of a balanced budget. By the fall of 1982, the United States was in a deep recession. Budget deficit predictions were as high as $\$ 200$ billion dollars and by the end of 1982 over 9 million Americans were officially unemployed. ${ }^{361}$ Reagan's

\footnotetext{
${ }^{358}$ Ronald Reagan, Speaking My Mind: Selected Speeches, p.62.

${ }^{359}$ Ronald Reagan, Ronald Reagan: An American Life, p.260.

${ }^{360}$ Steven F. Hayward, The Age of Reagan: The Conservative Counterrevolution 1980-1989, (United States: Three Rivers Press, 2009), p.146..

${ }_{361}$ Dinesh D'Souza, Ronald Reagan: How an Ordinary Man Became an Extraordinary Leader, (New York: Touchstone Publishing, 1997), p 25.
} 
economic platform was fast being unravelled and the Republican Party was punished in the midterm elections in 1982, when the Democratic Party picked up 26 seats in the House of Representatives. Following the midterm elections, the unemployment rate rose to 11.5 million people and at the same time, Reagan's approval rating plummeted to just $35 \%$, the worst of his presidency. ${ }^{362}$ With the worst economic conditions since the Great Depression, people began to talk about another one-term failed presidency. However the economy slowly began to turn around and, by the spring of 1983, it began to take off. The economic expansion lasted 93 consecutive months and was the biggest peace time economic expansion in American history, creating over 18 million new jobs. ${ }^{363}$

While the focus of the first term was on the economy, other issues dominated Reagan's time, one of those was the Air Traffic Controllers strike. In August 1981, the Professional Air Traffic Controllers Organisation (PATCO) declared they were going on strike, threatening to bring airplane travel to a halt. Reagan gave the workers 48 hours to return to work before they would lose their jobs. Reagan refused to negotiate with the PATCO and when only $38 \%$ of the controllers returned to work he fired the rest and replaced them temporarily with military personnel. Air travel returned to normal with no major incidents. 'The crushing of the PATCO strike highlighted the arrival of an anti-union regime in Washington, but more importantly it burnished Reagan's image as a forceful leader, willing to take risks and act decisively on matters of principle. ${ }^{364}$ Reagan's stance was popular with the American people, with more than two-thirds supporting his stance. ${ }^{365}$

In October 1983, suicide bombers bombed the United States army barracks in Beirut, killing 241 US Marines. Reagan remembered it as 'the saddest day of my presidency, perhaps the saddest day of my life. ${ }^{366}$ The bombing of the army barracks led to the withdrawal of the international

\footnotetext{
362 PBS, 'Timeline: Ronald Reagan's Life' ,www.pbs.org/wgbh/americanexperience/features/timeline/reagan, (14 April 2012). 363 Ibid.

364 Jules Tygiel, Ronald Reagan and the triumph of American Conservatism, p.159.

365 Ibid.

${ }^{366}$ Ronald Reagan, Ronald Reagan: An American Life, p.437.
} 
peacekeeping force in Lebanon. ${ }^{367}$ That same month, the United States invaded Grenada following a bloody military coup on the island, with American medical students being held hostage. Reagan was also weary of the Soviet and Cuban influence in the region despite popular support in the United States; Great Britain would oppose the invasion. Thirty hours after the invasion by 400 marines, the first medical students arrived back in the United States. ${ }^{368}$ Ultimately the invasion would restore constitutional government on the island and Reagan's intervention was seen largely as a success. By the end of Reagan's first term the economy was booming and the unemployment rate was dropping. Reagan's approval ratings had risen from a low of $35 \%$ in 1983 to $53 \%$ just before the 1984 election. ${ }^{369}$ Reagan was on a roll and, as his 1984 campaign slogan cleverly stated, 'It was morning again in America.' Americans once again felt proud to be American. With the economic growth washing over the country, there was a sense of optimism that America's best days were to come. This was a stark change to the final days of the Carter administration.

Reagan's second term: 1985-1989

Reagan's landslide re-election victory in 1984 was less than 4000 votes away in Minnesota, from creating the fifty-state sweep. However, Reagan's second term was filled with scandal, and the focus turned from the economy to foreign policy.

The Iran-Contra affair became the biggest scandal of Reagan's presidency. The scandal broke in 1986 and surrounded two matters; arms sales to Iran, and the funding of Contra Militants in Nicaragua. This secret arrangement provided funds to the Nicaraguan contra rebels from the profits of selling arms to Iran. There were two separate initiatives from the Reagan administration: the first was the commitment to aid the contras

\footnotetext{
${ }^{367}$ Lou Cannon, President Reagan: The Role of a Lifetime, (USA: Public Affairs, 2000), p.489. 368 lbid, pp.392-393.

${ }^{369}$ Gallup, 'Presidential Job Approval Centre', http://www.gallup.com/poll/124922/PresidentialApproval-Center.aspx, (23 April 2012).
} 
who were engaged in a guerrilla war against the Sandinista government. The second surrounded Iran, where the government sold arms to Iran in exchange for the release of American hostages held by pro-Iranian groups in Lebanon and to influence Iranian foreign policy in a pro-western direction. ${ }^{370}$ This secret arrangement was first reported in a Lebanese newspaper, which forced the administration to disclose the secret arms deals. On the $13^{\text {th }}$ of November 1986, Reagan presented a speech to the nation where he admitted sending some weapons and spare parts to Iran, but at the same time denied it was part of an 'arms for hostages' deal. ${ }^{371}$ Following this speech Attorney General Messe was asked to conduct an inquiry into the Iran affair. During the inquiry, Messe discovered that money was given to the contras and arms were given to Iran. National Security Advisor John Poindexter resigned and Oliver North was fired. On December $1^{\text {st }}$, Reagan appointed the Tower commission to review the Iran-Contra scandal and testified to the Tower Commission, stating that he did not remember in any period, any of the events that occurred. On February $26^{\text {th }} 1987$, the Tower Commission reported stated that it did not link Reagan to a diversion of funds from Iran to the Contras. The report concluded that Reagan allowed himself to be misled by dishonest staff members. Following the release of the tower commission report, Reagan fired his Chief of Staff Donald Regan. ${ }^{372}$ Reagan's approval rating was severely affected by the Iran-Contra scandal. In late 1986 his approval rating dropped from $67 \%$ to $46 \%$ in one month and by February 1987 his it had dropped to only $42 \%$. These were the dark times of his administration when, in the 1986 Midterm elections, the Democratic Party won majorities in both the House and the Senate. In the Senate the Democrats gained eight seats and in the House the Democrats also made gains by winning a further five seats. ${ }^{373}$

Despite this scandal, Reagan's second term was focused on foreign policy and the opening up of a renewed dialogue with the Soviet Union.

\footnotetext{
${ }^{370}$ Adriana Bosch, Reagan: An American Story, p.304.

371 Ibid.

372 Ibid.

${ }^{373}$ PBS, 'Timeline: Ronald Reagan's Life' ,www.pbs.org/wgbh/americanexperience/features/timeline/reagan, (14 April 2012).
} 
Reagan's first contact with the Soviet Union came late in his first term when he met Soviet Foreign Minister Andrei Gromyko. Although little progress was made, Reagan demonstrated that US-Soviet relations had his personal attention and were a high priority. ${ }^{374}$ The first official summit was held between Mikhail Gorbachev and Reagan in Geneva in November 1985. A scheduled fifteen minute meeting between the leaders turned into a one-hour meeting. The major disagreement of this summit concerned Reagan's SDI (Strategic Defence Initiative). This initiative was proposed by Reagan in 1983 to use ground and space-based systems to protect the United States from attack by nuclear ballistic missiles. Reagan argued that SDI would not be used to launch a first strike against the Soviet Union, but Gorbachev argued that SDI would open up an arms race in space. ${ }^{375}$ Although the summit ended in disagreement over the SDI, there was a mutual pledge to seek a 50\% reduction in nuclear arms. ${ }^{376}$ In 1986 a further summit was held in Reykjavik, Iceland, where Gorbachev called for drastic cuts in all classes of nuclear weapons on the proviso that Reagan confined SDI to the laboratory. Reagan did not agree to the terms Gorbachev outlined and walked away from the summit which was subsequently considered a failure. The big breakthrough in US-Soviet relations came on December $8^{\text {th }} 1987$, when the Washington Summit opened between Reagan and Gorbachev. The INF Treaty was signed which called for the elimination of $4 \%$ of the nuclear arsenals of these states. This was the first Treaty to be signed to provide for the destruction of nuclear weapons and to provide for onsite monitoring of the destruction of them. The Senate ratified the treaty in May 1988, making it the first arms-control agreement since $1972 .{ }^{377}$ Reagan's ability to open up a dialogue with the Soviet Union was remembered as one of his greatest achievements while in the Oval Office.

Perhaps one of Reagan's most famous speeches during his time as president was given on the June 12 1987, at the Berlin wall. Here, Reagan spoke directly to Gorbachev.

\footnotetext{
${ }^{374}$ Ronald Reagan, Ronald Reagan: An American Life, p.559.

375 lbid, p.519.

376 lbid.

377 Ronald Reagan, Ronald Reagan: An American Life, p.683.
} 
'General Secretary Gorbachev, if you seek peace, if you seek prosperity for the Soviet Union and Eastern Europe, if you seek liberalization: Come here to this gate! Mr Gorbachev, open this gate! Mr Gorbachev, tear down this wall! ${ }^{378}$

Reagan dismissed official advice from the State Department to deliver this statement to Mr Gorbachev. ${ }^{379}$ Reagan had left the White House when the Berlin wall came down in 1989, but he could take immense pride in the fact that his administration achieved much in its dealings with the Soviet Union and bringing the Cold War to an end.

Another event that stands out during Reagan's presidency was the Challenger space shuttle disaster. The Challenger disaster took place on the $29^{\text {th }}$ of January 1986, when, 73 seconds after take-off, the space shuttle exploded, killing six astronauts on board as well as teacher Christa McAuliffe, the first civilian to go into space. ${ }^{380}$

'The crew of the space shuttle Challenger honoured us by the manner in which they lived their lives. We will never forget them, nor the last time we saw them, this morning, as they prepared for their journey and waved good-bye and slipped the surly bonds of earth to touch the face of God. ${ }^{381}$

Reagan had the ability to heal a nation with his words. Despite this tragic event, he captured the mood of the public and the nation and time and time again, Reagan made use of his rhetorical skills to make the American public feel safe and proud.

Despite the second term focus on foreign affairs, Reagan never let up in his desire for tax reform. Lou Cannon argued that the Tax Reform Act of 1986 was 'arguably the most important domestic accomplishment of Reagan's second term. ${ }^{382}$ The Act simplified the income tax code by lowering the top tax rate to $28 \%$, broadened the tax base and eliminating tax loop holes. The Act was seen as the second tranche of Reagan's economic reform that started with the Economic Recovery Tax Act of 1981. 'By cutting the top individual rate to $28 \%$ cemented in place

\footnotetext{
${ }^{378}$ Ibid, p.348.

${ }^{379}$ Ibid.

${ }^{380}$ Ronald Reagan, Ronald Reagan: An American Life, p.403.

381 lbid, p.292.

${ }^{382}$ Lou Cannon, President Reagan: The Role of a Lifetime, p.489.
} 
Reagan's fundamental victory in reorienting tax policy. Despite subsequent increases in the top marginal rate, the 1986 tax reform foreclosed the possibility of using the income tax code for purposes of punishing the rich or redistributing wealth in any significant way. ${ }^{383}$

Despite the Iran-Contra affair, Reagan remained popular throughout his second term. In July 1986, Reagan had a 68\% approval rating, the economy was booming and Americans felt once again strong and proud to be American. In June 1988, with a growing economy, the United States unemployment rate hit a 14 year low. ${ }^{384}$ Reagan gave his farewell address to the nation on the $11^{\text {th }}$ of January 1989.

'We've done our part. And as I walk off into the city streets, a final word to the men and women of the Reagan revolution, the men and women across America who for eight years did the work that brought America back. My friends: We did it. We weren't just marking time. We made a difference. We made the city stronger. We made the city freer, and we left her in good hands. All in all, not bad, not bad at all. ${ }^{385}$

Reagan believed that his Presidency had made a difference to ordinary Americans. Lou Cannon argued that 'since the turn of the century, no president save FDR defined a decade as strikingly as Ronald Reagan defined the 1980s. Reagan's geniality, his stubborn individualism and antiintellectualism, his self-deprecating wit, and his passionate opposition to taxes set the tone for a decade that was at once a period of national renewal and national excess. ${ }^{386}$ Reagan had inherited an economy in recession, the worst since the Great Depression, and turned it into the longest peacetime boom in history. The economic boom created 18.4 million new jobs and the economy grew for 93 consecutive quarters. Even though the real income of every strata of Americans increased during the 1980s after declining during the 1970's, that increase was very uneven, with the rich getting richer. ${ }^{387}$ While Chapter Six of this thesis will analyse

\footnotetext{
${ }^{383}$ Steven F. Hayward, The Age of Reagan: The Conservative Counterrevolution 1980-1989, p.477.

${ }^{384}$ ABC News, 'End of Presidency Approval Rating', http://abcnews.go.com/sections/politics/DailyNews/poll clintonlegacy010117.html, (22 April 2012).

${ }^{385}$ Reagan, Ronald, 'Speaking My Mind: Selected Speeches', p.409.

${ }^{386}$ Lou Cannon, President Reagan: The Role of a Lifetime, p.746.

${ }^{387}$ Ibid.
} 
in greater detail the impact of the Reagan presidency, the economic recovery and Reagan's engagement with the Soviet Union was his greatest legacy.

\section{Barack Obama and the promise of hope and change}

Obama's first term: 2009-2013

'Our time of standing apart, of protecting narrow interests and putting off unpleasant decisions - that time has surely passed. Starting today, we must pick ourselves up, dust ourselves off, and begin again the work of remaking America. ${ }^{388}$

Barack Obama Inaugural Address, 20 January 2009.

Obama was elected as the $44^{\text {th }}$ President of the United States in 2008. Several key events would dominate Obama's first term: the financial crisis, the on-going wars in Iraq and Afghanistan and the passing of the historic Healthcare legislation. Once elected, Obama wasted no time getting to work implementing the programme he campaigned on. In the first few days of his presidency Obama issued executive orders and memoranda directing the United States Military to develop plans to withdraw troops from Iraq. The first bill that Obama signed into law was the Lilly Ledbetter Fair Pay Act which was signed into law on January 29, 2009. The law promotes fair pay, regardless of sex, race or age.

\section{Obama and the Economic Recession}

The overarching issue of Obama's first term was the economic crisis. In the six months before Obama was sworn in as president, the United States economy shed 3.5 million jobs. Obama got straight to work attempting to pull America from the worst recession since the Great Depression. A little over a month after Obama was sworn in as president,

\footnotetext{
${ }^{388}$ Barack Obama, 'Inaugural Address January 20, 2009, in My Fellow Americans: Presidential Inaugural Addresses from George Washington to Barack Obama, p.389.
} 
on 17 February, 2009, the administration secured the congressional passage of a $\$ 787$ billion federal stimulus package (increased to $\$ 840$ billion as consistent with Obama's 2012 Budget) - the American Recovery and Reinvestment Act. ${ }^{389}$ The Act provided the largest tax cut for the middle class since the Reagan administration, the biggest infrastructure bill since the Eisenhower administration, the biggest antipoverty and job training bill since the Johnson administration, the biggest education bill since the Johnson administration, the biggest clean energy bill ever, and huge investments in housing and scientific research. ${ }^{390}$

The main provisions of the American Recovery and Reinvestment Act were:

- To preserve and create jobs and promote economic recovery.

- To assist those most affected by the recession.

- To provide investments needed to increase economic efficiency by spurring technological advances in science and health.

- To invest in transportation, environmental protection, and other infrastructure that will provide long-term economic benefits.

- To stabilize State and local government budgets, in order to minimize and avoid reductions in essential services and counterproductive state and local tax increases. ${ }^{391}$

The bill included $\$ 297.8$ billion in tax benefits, including incentives for individuals and businesses; $\$ 231.1$ billion in contracts, grants and loans to be spent on education, transportation, infrastructure, energy/environment, housing, health and R\&D/science; and $\$ 224$.3 billion on entitlements, including Medicare/Medicaid, unemployment insurance programs, family services, economic recovery payments and energy. ${ }^{392}$

\footnotetext{
${ }^{389}$ United States Government, How the funds are allocated, http://www.recovery.gov/Transparency/fundingoverview/Pages/fundingbreakdown.aspx, (Assessed 28 April 2012).

390 Garren Dorrien, The Obama Question: A Progressive Perspective, p.3.

391 United States Government, The Recovery Act, http://www.recovery.gov/About/Pages/The Act.aspx, (Assessed 28 April 2012).

${ }^{392}$ United States Government, How the funds are allocated, http://www.recovery.gov/Transparency/fundingoverview/Pages/fundingbreakdown.aspx, (Assessed 28 April 2012).
} 
Obama was also faced with another important decision early in his presidency: whether to save the United States auto industry. When Obama was elected, the auto-industry was on the brink of collapse and in December 2008 it was announced that a $\$ 17.4$ billion dollar lifeline would be given to Detroit car makers from the TARP (Troubled Asset Relief Program). In June 2009, Obama made the decision to bailout the auto industry after General Motors filed for bankruptcy. The treasury provided a $\$ 30$ billion loan to General Motors. Further federal aid was provided to Detroit car makers despite widespread opposition. ${ }^{393}$ In March 2012, Obama discussed the bailout in a radio address to America. In his statement Obama argued:

'If we had let this great American industry collapse - if we had let Detroit go bankrupt - more than 1 million Americans would have lost their jobs in the middle of the worst recession since the Great Depression. In exchange for help, we demanded responsibility. We got the companies to retool and restructure.

Everyone sacrificed. And three years later, the American auto industry is back. ${ }^{394}$

Obama was correct in bailing out the auto industry, as more than one million Americans would have lost their jobs. Obama demanded the auto makers restructure their operations and today General Motors is the number one auto maker in the world and has announced plans on investing over $\$ 2$ billion in seventeen American plants. Chrysler is currently growing faster in America than any other car company and over the past two and a half years the auto industry has added over 200,000 new jobs. ${ }^{395}$

Obama inherited an economy on the brink of collapse. He set to work immediately by passing economic stimulus and bailing out the autoindustry. He operated in the face of stiff Republican opposition that opposed all policy proposals. The 2011 Debt Ceiling Crisis personified

\footnotetext{
${ }^{393}$ Mary Bruce, Obama's weekly address: Defending the auto bailout, (March 3 2012), http://abcnews.go.com/blogs/politics/2012/03/obamas-weekly-address-defending-the-auto-bailout/, (28 April 2012). 394 Ibid. ${ }^{395}$ Ibid.
} 
this, with Republicans calling for stiff budgetary cuts. Despite the opposition there were signs of an improving economy. The unemployment rate that peaked at $10 \%$ in October 2009 dropped to $7.8 \%$ in October 2012, still historically high, but is expected to continue to fall. ${ }^{396}$ During Obama's first term the American economy created 5.2 million private sector jobs and saw 31 straight months of job growth. ${ }^{397}$

\section{The passing of historic Health Care Reform}

The cornerstone of Obama's 2008 presidential campaign was healthcare reform. The call for healthcare reform began during the presidential campaign of Teddy Roosevelt in the early $20^{\text {th }}$ century and had continued through the New Deal and President Harry Truman who called for 'compulsory health insurance' at the end of the Second World War. President's Kennedy, Nixon and Carter all argued for access to universal Health Care. More recently President Clinton argued for 'health care that's always there, health care that can never be taken away. ${ }^{, 398}$ While Universal health care was established in every industrialised country, health care reformers had run into bitter opposition in the United States. Obama campaigned to bring affordable health care for all Americans. Obama argued that, 'one of the biggest drains on Americans pocketbooks is the high cost of health care, and among the biggest insecurities that families face is the threat of losing their health care coverage or getting sick or injured and not being able to afford high-quality care. ${ }^{399}$

The Patient Care and Affordable Care Act 2010 aimed to introduce new benefits for health care in America:

\footnotetext{
${ }^{396}$ United States Bureau of Labour Statistics, Employment Situation Summary, (October 2012), http://www.bls.gov/news.release/empsit.nr0.htm, (26 October 2012).

${ }^{397}$ Barack Obama, The President's Record on Job Creation, (October 2012), http://www.barackobama.com/record/economy?source=footer-nav, (26 October 2012).

${ }^{398}$ Lawrence R. Jacobs and Theda Skopol, Health Care Reform and American Politics, (New York: Oxford University Press, 2010), p.3.

${ }^{399}$ Barack Obama, Change we can believe in: Barack Obama's plan to renew America's promise, (New York: Three Rivers Press, 2008), p.42.
} 
- Expanded access to Medicaid (the federal-state insurance program for low-income people) for thirty-two million Americans who lack insurance.

- Subsidies to help small businesses and individuals with modest means to help purchase health coverage.

- For older people on Medicare, the Act promises free preventive check-ups and more complete subsidies for prescription drug coverage.

- Regulatory protection for the 176 million Americans who already have health insurance, so that by 2014 private insurers will no longer be able to avoid or cut people with "pre-existing" health conditions.

- By the end of 2010 private insurers had to cover children, regardless of health problems, and allow young adults to remain on parental insurance plans until age 26.

- The new law requires virtually all Americans, starting in 2014, to buy basic health insurance coverage..$^{400}$

Following Obama's inauguration, bitter partisan opposition erupted, with Republicans refusing to vote in favour of the legislation. On January 19, 2010, following the death of Massachusetts Senator Edward Kennedy, Republican Scott Brown defeated Democrat Martha Coakley to fill the senate seat. This was a bitter blow to Obama who needed all the support he could muster to get the bill passed. Despite the setbacks, Obama pushed on and on March 21, 2010, in a vote of 219-212 the House passed the Senate version of health care reform, the Patient Protection and Affordable Care Act, H.R. 3590.By a vote of 220-211, the House passed the "sidecar" bill that revises the Senate legislation, the Health Care and Education Reconciliation Act, H.R. 4872. Two days later, Obama signed the Patient Protection and Affordable Care Act, into law. That same day, Attorneys General in fourteen states sued to block healthcare reform law. On March 26, the Senate voted for the reconciliation fixes, the Health Care and Education Reconciliation Act, by a vote of 56-

${ }^{400}$ Lawrence R. Jacobs and Theda Skopol, Health Care Reform and American Politics, p.4. 
43. The Republicans managed to force the House to vote on the legislation again and it passed a second time, 220-207. On March 30, Obama signed the Act into law. ${ }^{401}$ The reform was ridiculed by the Republican Party and was one of the major triggers of the birth of the Tea Party. Americans are largely against the reforms - a Rasmussen poll in November 2012 taken directly before the 2012 election had American's favouring repeal $50 \%$ to $44 \%$ against repealing. ${ }^{402}$

The Democratic controlled Congress faced an uphill battle in the lead up to the Midterm elections in 2010. The state of the economy, the passing of unpopular healthcare reforms and the rise of the Tea Party, meant the winds of discontent were blowing. Ultimately, the Democratic Party would lose control of the house while holding onto the Senate with a reduced majority. The Democratic Party lost 63 seats in the House, making it the largest seat change since the 1948 elections. When the dust settled the Democrats held 193 seats in the House, compared to 242 seats for the Republicans. The Republicans gained six seats in the senate to hold 47 seats, compared to 53 seats for the Democrats. Former advisor to President Bill Clinton and Fox News Contributor, Dick Morris described the result as a rebirth of the Republican right, spelling doom for the Obama Presidency. ${ }^{403}$ Many were starting to talk about a one-term presidency for Obama.

In June 2012, the United States Supreme Court ruled 5-4 that the individual mandate requiring people to have health insurance is valid as a tax, even though it is impermissible under the constitution's commerce clause. The announcement was seen as a victory for Obama's flagship policy. Obama acknowledged that the issue had been divisive, but maintained that the policy was not driven by politics:

\footnotetext{
${ }^{401}$ lbid, pp.14-16.

402 Rasmussen Reports, Health Care Law, http://www.rasmussenreports.com/public content/politics/current events/healthcare/health care law, (Assessed 5 November 2012).

${ }^{403}$ Dick Morris, The New Republican Right, (20 October 2010), http://www.realclearpolitics.com/articles/2010/10/20/the new republican right 107653.html, (28 April 2012).
} 
'Today's decision was a victory for people all over this country whose lives are more secure because of this law... I know the debate over this issue has been divisive. It should be pretty clear that I didn't do this because it was good for politics. I did it because I believe it was good for the country. ${ }^{404}$

\title{
Obama and the World
}

It was not only on the domestic front where Obama was able to make gains. In the foreign affairs policy sphere, Obama campaigned on withdrawing American troops from the wars in Iraq and Afghanistan. Arguably America's reputation around the world was at an all-time low when Obama assumed the presidency. Journalist Fareed Zakaria argues that, 'Barack Obama has been a strong president when it comes to foreign policy and has pursued an effective foreign policy. The Republicans only seldom attack Obama on the issue. ${ }^{405}$

Obama's first foray into foreign policy came early on in his presidency in June 2009. Obama delivered an address in Cairo, Egypt in an attempt to reach out to the Muslim world and help repair and restore the image of America around the world. In the speech, Obama stated:

\begin{abstract}
'I have come here to seek a new beginning between the United States and Muslims around the world; one based upon mutual interest and mutual respect; and one based upon the truth that America and Islam are not exclusive, and need not be in competition. Instead, they overlap, and share common principles principles of justice and progress; tolerance and the dignity of all human beings. I do so recognizing that change cannot happen overnight. No single speech can eradicate years of mistrust, nor can I answer in the time that I have all the complex questions that brought us to this point. ${ }^{406}$
\end{abstract}

\footnotetext{
${ }^{404}$ Bill Mears and Tom Cohen, 'Emotions high after Supreme Court upholds healthcare law,'(29 June 2012), www.cnn.com/2012/06/28/politics/supreme-court-health-ruling/index/htm, (26 October 2012). ${ }^{405}$ Fareed Zakaria, Obama the Strategist, (19 January 2012), http://globalpublicsquare.blogs.cnn.com/2012/01/19/zakaria-obama-the-strategist/?iref=allsearch, (28 April 2012).

${ }^{406}$ Barack Obama, Obama's Speech in Cairo, (4 June 2009), http://www.nytimes.com/2009/06/04/us/politics/04obama.text.html?pagewanted=all , (28 April 2012).
} 
Obama's speech was widely acclaimed around the world and was the beginning of a shift towards reconciliation with the Muslim world, after the suspicion and division advocated by the Presidency of George W. Bush.

On May 1, 2011, President Obama announced to America and the world that the mastermind of the September 11 terrorist attacks in America, Osama Bin Laden, had been killed. The attack was ordered by Obama and Bin Laden was killed in Northern Pakistan after a Navy Seal team raided Bin Laden's compound in Abbottabad. There was widespread acclaim following the announcement with crowds gathering outside the White House to celebrate. ${ }^{407}$ In his speech, Obama stated:

'Good evening. Tonight, I can report to the American people and to the world that the United States has conducted an operation that killed Osama bin Laden, the leader of al-Qaeda, and a terrorist who's responsible for the murder of thousands of innocent men, women, and children. It was nearly 10 years ago that a bright September day was darkened by the worst attack on the American people in our history...The cause of securing our country is not complete. But tonight, we are once again reminded that America can do whatever we set our mind to. That is the story of our history, whether it's the pursuit of prosperity for our people, or the struggle for equality for all our citizens; our commitment to stand up for our values abroad, and our sacrifices to make the world a safer place. ${ }^{408}$

With this, Obama was able to close one chapter of American history by bringing justice and closure to those who were affected by the September 11 terrorist attacks.

Obama campaigned on bringing a responsible end to the War in Iraq. Obama opposed the War in Iraq from the beginning and, on 31 August, 2010, delivered an address to the nation. In his address, Obama stated:

'The United States has paid a huge price to put the future of Iraq in the hands of its people. We have sent our young men and women to make enormous sacrifices in Iraq, and spent vast resources abroad at a time of tight budgets at home. We have

\footnotetext{
${ }^{407}$ Emily Babay, Crowds Rejoice at White House after news of Bin Laden's death, (2 May 2011), http://washingtonexaminer.com/local/dc/2011/05/crowds-rejoice-white-house-after-news-bin-ladensdeath/113539, (28 April 2012).

${ }^{408}$ Daily Telegraph, Osama Bin Laden Killed: Barack Obama Speech in Full, (2 May 2011), http://www.telegraph.co.uk/news/worldnews/barackobama/8487354/Osama-bin-Laden-killed-BarackObamas-speech-in-full.html, (28 April 2012).
} 
persevered because of a belief we share with the Iraqi people-a belief that out of the ashes of war, a new beginning could be born in this cradle of civilization.

Through this remarkable chapter in the history of the United States and Iraq, we have met our responsibility. Now, it is time to turn the page. ${ }^{409}$

On 18 December, 2011, the last American troops departed Iraq. Obama was successful in fulfilling a campaign promise to bring about a responsible end to the war in Iraq. Obama also laid out an exit plan to end the war in Afghanistan. These achievements are no small feat. Obama inherited two costly and on-going wars and a major part of his legacy will be the ending of those wars.

Despite the focus on the economy, healthcare and foreign policy, Obama made other significant advances during his first term. Those included overturning the ban on Stem Cell Research, nominating and confirming two new Supreme Court Justices, and signing the Don't Ask, Don't Tell Repeal Act of 2010, repealing the 1993 Don't Ask, Don't Tell rule that prevented openly gay and lesbian people from serving in the United States Armed Forces.

${ }^{409}$ New York Times, President Obama's Address on Iraq, (31 August 2010), http://www.nytimes.com/2010/09/01/world/01obama-text.html? $\quad r=1$ \&pagewanted=1\&ref=world, (Assessed 28 April 2012). 


\section{Chapter Six: Is Obama the next reconstructive President?}

'It's been a long time coming, but tonight, because of what we did on this day, in this election, at this defining moment, change has come to America. $^{, 410}$

President-elect Barack Obama Election Night 2008 Speech

President Obama campaigned in 2008 to transform and reconstruct America. Obama campaigned on the mantra of 'Hope and Change'. The election of Obama was historic in its own right as he was elected as the first black president of America. But the central question of this thesis is whether President Obama will be remembered as a President of reconstruction. Before analysing whether Obama will be remembered alongside Jefferson, Jackson, Lincoln, FDR and Reagan as a reconstructive president or as a pre-emptive president, this chapter will discuss and outline Obama's admiration of Reagan's leadership before posing the question: How reconstructive was Reagan's presidency?

Firstly, Skowronek argues that American government and politics are transformed when:

1. New interests secure a firm grip on power,

2. Institutional relationships are rearranged to support them,

3. Governmental priorities are durably recast,

4. A corresponding set of legitimating ideas becomes the new common sense. ${ }^{411}$

The five reconstructive presidents have at different levels completed the four variables as outlined above and, with different degrees of success, have transformed America.

${ }^{410}$ Barack Obama, 'Remarks by President-Elect Barack Obama: Election Night Victory Speech,' in Mary Frances Berry and Josh Gottheimer, Power in Words: The stories behind Barack Obama's Speeches, From the State House to the White House, (Boston: Beacon Press, 2010), p.251.

${ }^{411}$ Stephen Skowronek, Presidential Leadership in Political Time: Reprise and Reappraisal, p.171. 


\section{Reagan: A role model for Obama}

During the 2008 Democratic nomination, candidate Obama caused controversy when he said in a January 2008, interview with the Reno Gazette-Journal:

'I think Ronald Reagan changed the trajectory of America in a way that Richard Nixon did not and in a way that Bill Clinton did not. He put us on a fundamentally different path because the country was ready for it... I think they felt like with all the excesses of the 1960s and 1970s and government had grown and grown but there wasn't much sense of accountability in terms of how it was operating. I think he just tapped into what people were already feeling, which was we want clarity, we want optimism, we want a return to that sense of dynamism and entrepreneurship that had been missing. ${ }^{412}$

President Obama is well aware of his Presidential predecessors. In May 2010, Obama invited a small group of presidential historians to the White House for dinner. It was the second of such dinners to be held in the White House, but according to those historians present, it soon became clear that, 'Obama seemed less interested in talking about Lincoln's team of rivals or Kennedy's Camelot than the accomplishments of an amiable conservative named Ronald Reagan, who had sparked a revolution three decades earlier when he arrived in the Oval Office. ${ }^{413}$ While Obama and Reagan share a number of gifts, it's important to note that they don't share many priorities. At the dinner, Obama was most impressed by the way Reagan had transformed American's attitude about government. Douglas Brinkley, who edited Reagan's diaries and who attended the dinner was left with the impression that Obama had found a role model. 'There are policies, and there is persona, and a lot can be told by persona. Obama is approaching the job in a Reaganesque fashion. ${ }^{414}$

\footnotetext{
${ }^{412}$ Shailagh Murray, 'Obama's Reagan Comparison sparks debate,' Washington Post, January 17 2008, http://voices.washingtonpost.com/44/2008/01/obamas-reagan-comparison-spark-1.html, (Assessed 24 November 2012).

${ }^{413}$ Michael Sherer and Michael Duffy, 'The Role Model: What Obama sees in Reagan,' in Time Magazine, February 7 2011, p.14. 414 lbid.
} 
When Obama is asked by reporters about what president he looks up to, his answer is not fellow Democrats, FDR or Clinton, but Reagan and Lincoln. In Obama's book The Audacity of Hope, he wrote:

'Reagan spoke to America's longing for order, our need to believe that we are not simply subject to blind, impersonal forces but that we can shape our individual and collective destinies, so long as we rediscover the traditional virtues of hard work, patriotism, personal responsibility, optimism, and faith. ${ }^{415}$

It is interesting that Obama would single out Reagan, a staunch Republican as someone who he wishes to emulate, just as Reagan looked back with fondness to the presidency of FDR. Skowronek touches on this exact point:

'When Abraham Lincoln invoked the spirit of Thomas Jefferson and Ronald Reagan quoted Franklin Roosevelt, they were appealing to political identities that have little to do with the party of substantive vision of the man they were claiming as a soul mate. They were rather calling attention to these parallel moments in political time, and invoking the names of historical counterparts with whom they shared a more basic leadership project. ${ }^{416}$

Obama also wrote a piece for the USA Today newspaper to celebrate the 100 year birthday of Reagan. In this piece, Obama eloquently stated,

'Ronald Wilson Reagan was a believer. As a husband, a father, an entertainer, a governor and a president, he recognised that each of us has the power - as individuals and as a nation - to shape our own destiny. He had faith in the American promise; in the importance of reaffirming values like hard work and personal responsibility and in his own unique ability to inspire others to greatness. $^{417}$

Obama would go on to point out that no matter what disagreements you might have had with Reagan, there is no denying his leadership in the world, or his gift for communicating his vision for America. ${ }^{418}$

\footnotetext{
${ }^{415}$ Barak Obama, The Audacity of Hope: Thoughts on Reclaiming the American Dream, p.31.

${ }^{416}$ Stephen Skowronek, The Politics Presidents Make: Leadership from John Adams to Bill Clinton, p.51-52.

${ }^{417}$ Barack Obama, 'Dedication to Ronald Wilson Reagan,' in USA Today: Special Centennial Edition: Reagan - An American Icon, February 28 2011, p.29.

${ }^{418}$ Ibid.
} 


\section{Reagan: A reconstructive president?}

Stephen Skowronek argues that Reagan is one of five presidents who successfully repudiated the failed policies of their predecessor. A lofty comparison for one to make, which poses the question, how reconstructive was Reagan's presidency?

'Had Ronald Reagan not played the part of the great repudiator so broadly and George Bush not rendered the travails of the faithful son so poignantly, it would be easier to endorse the prevailing view that the politics of leadership is dramatically different now than it was two hundred years ago. ${ }^{419}$

Skowronek argues that after 200 years of national development, presidents are still trying to make the same kinds of politics. ${ }^{420}$ The presidencies of Carter, Reagan and Bush in the twentieth century, 'bear an eerie, almost surreal, resemblance' to that constructed in the $19^{\text {th }}$ century by John Quincy Adams, Andrew Jackson and Martin Van Buren. ${ }^{421}$

Skowronek describes Reagan during the 1980 presidential election as a leader of an insurgency that had been targeting the liberal regimes most basic commitment:

'Candidate Reagan had little patience with Carter's efforts to distance himself from its failures. He deftly turned the president's difficulties into proof that something fundamental was wrong with liberal government. ${ }^{422}$

Reagan argued that the old order was bankrupt and that Carter and the liberal defenders were directly responsible for the national crisis. Reagan stated at the 1980 Republican National Convention:

'The major issue in this campaign is the direct political, personal, and moral responsibility of the Democratic Party leadership - in the White House and in the Congress - for this unprecedented calamity which has befallen us. ${ }^{, 423}$

\footnotetext{
${ }^{419}$ Stephen Skowronek, The Politics Presidents Make: Leadership from John Adams to Bill Clinton, P.409.

${ }^{420}$ Ibid.

${ }^{421}$ lbid, 410.

${ }^{422}$ Stephen Skowronek, Presidential Leadership in Political Time: Reprise and Reappraisal, p.93.
} 
Once elected Regan stated at his inaugural address, 'in the present crisis, government is not the solution to our problems, government is the problem. ${ }^{424}$ Reagan's reconstruction was ideological in nature. Reagan posted a choice of not only between left and right, but up and down, 'down through the welfare state to statism and up to the ultimate in individual freedom as conceived by the founding fathers. ${ }^{, 425}$ By reaching back to 'emblematic values allegedly squandered in the indulgences of the old order, Reagan was able to harness the disruptive order shattering effect of the exercise of presidential power to an order-affirming purpose and to engage in an extensive reconstruction of the terms and conditions of legitimate national government. ${ }^{426}$ Reagan clearly understood his place in history and understood that his presidency had created a realignment of American society. In his farewell address to the nation, Reagan stated,

'They called it the Reagan Revolution. Well I'll accept that, but for me it always seemed more like the great rediscovery, a rediscovery of our values and our common sense. ${ }^{427}$

Reagan's reconstruction and legacy has been distorted over time by the Republican Party, for their own political gains. Reagan has taken on a somewhat mythological status inside the Republican Party. Mark Barabak argues that Reagan has become a 'sainted figure in the Republican Party who, not incidentally, is the most successful and popular of the party's modern presidents. But the Reagan reverie overlooks much of the Reagan reality. ${ }^{428}$ Barabak goes onto argue that:

'As president, the conservative icon approved several tax increases to deal with a soaring deficit, repeatedly boosted the nation's debt limit, signed into law a bill granting amnesty to millions of illegal immigrants and, despite his anti-Washington rhetoric, oversaw an increase in the size and spending of the federal government. $^{429}$

\footnotetext{
${ }^{423}$ Ibid.

${ }^{424}$ Ibid.

425 lbid, p.95.

${ }^{426}$ Ibid.

${ }^{427}$ Ibid.

${ }^{428}$ Mark Barabak, 'Reagan takes on mythological status,' in The Dominion Post, Friday September 9 , 2011 , p.B2.

${ }^{429}$ Ibid.
} 
Despite the myths that today have formed the legacy of Reagan, no one can deny he changed the direction of America and restored its selfconfidence - a strength that had been declining since the Vietnam War and which hit rock bottom during the Carter years.

Obama summed up Reagan's gift when he stated, 'when the future looked darkest and the way ahead seemed uncertain, President Reagan understood both the hardships we faced and the hopes we held for the future. He understood that it is always "Morning in America." That was his gift, and we remain forever grateful. ${ }^{430}$ On the face of it, Reagan transformed the mood of America during his presidency.

Reagan has often been described as 'the great communicator 'and in his own words Reagan argued that 'our words are our legacy, an inheritance we leave to those who can use what we no longer can. ${ }^{431}$ While Reagan's rhetoric argued for smaller government, he oversaw a ballooning deficit and created an unequal America. Reagan's reconstruction was, by historical standards, played out as more rhetorical than institutional, its comparatively shallow foundations laid on an ideological aversion to red ink. 432

Overall, Jon Johansson argues that Reagan doesn't easily fit with the other reconstructive presidents.

'His policy achievements are a chimera, ephemeral rather than substantive, unless a legacy of huge deficits and an exponentially exploding national debt is judged a success. $^{433}$

Johansson confirms that Reagan's reconstruction was more rhetorical in nature. While more superficial when compared to his reconstructive predecessors, Reagan's reconstruction is no less powerful as his

\footnotetext{
${ }^{430}$ Barack Obama, 'Dedication to Ronald Wilson Reagan,' in USA Today: Special Centennial Edition: Reagan - An American Icon, February 28 2011, p.29.

${ }^{431}$ Dick, Wirthlin, The Greatest Communicator: What Ronald Reagan Taught Me about Politics, Leadership and Life, (USA: Wiley Publishing, 2004), p.5.

432 Stephen Skowronek, Presidential Leadership in Political Time: Reprise and Reappraisal, p.95

433 Jon Johansson, Fulbright Speech.
} 
message has become the standard for the Republican Party today; 'lower taxes and less government still strongly resonate as the Republican's raison d'etre. ${ }^{434}$ Finally, Johansson states that Clinton had to re-create himself as a 'New Democrat' to get elected president in 1992, in recognition of the altered political discourse. George W. Bush's presidency 'promised to secure and complete the Reagan revolution and was successful up until the time Hurricane Katrina hit in 2005. ${ }^{435}$ Despite the superficial nature of Reagan's reconstruction, no one can argue that the rhetoric and ideas behind Reagan's revolution haven't been enduring. Even today, the notion of a smaller government with cuts to government spending prevails not only within the Republican Party, but across American society.

\section{Obama: following in the footsteps of Reagan?}

Candidate Obama argued for a new kind of politics and set aside the example of the most recent Democrat in the White House, Bill Clinton, as temporising and, by taking a larger view of his prospects, projected himself into one of those rare moments in American history when it becomes possible to alter the nation's trajectory. Obama spoke of fundamentally 'transforming the United States of America'. ${ }^{436}$

Skowronek raises an interesting point when discussing reconstructive presidents:

'Certainly it is no accident that the presidents most widely celebrated for their mastery of American political have been immediately preceded by presidents generally judged politically incompetent. John Adams and Thomas Jefferson, John Quincy Adams and Andrew Jackson, James Buchanan and Abraham Lincoln, Jimmy Carter and Ronald Reagan - this repeated pairing of dismal failure with stunning success is one of the more striking patterns in presidential history, and

\footnotetext{
434 Ibid.

435 lbid.

436 lbid, p. 167.
} 
accounting for it forces us to alter the way we have been thinking about that history. ${ }^{437}$

Before investigating whether Obama is like a reconstructive leader, one must look at George W. Bush's place in history. Skowronek argues that George W Bush is a second generation affiliate. Second generation affiliates have grown up with new dispensations, reflected in their stance as true believers poised to make the great leap forward on the received faith. ${ }^{438}$ The Bush victory in 2000 clearly demonstrated how little Clinton's presidency had done to define a compelling alternative around which the Democrats could rally the nation. ${ }^{439}$ Under Skowronek's model, second generation affiliates are not those who are overseeing a fractured and dying regime. Throughout much of Bush's presidency, the Republican Party stood behind their leader and supported his platform. Bush was able to gain the support of many in the Republican Party to authorise military action in Iraq in 2003 and it wasn't until after Hurricane Katrina in 2005 when cracks in the Republican resolve started seeping in. More importantly, it was the 2006 Mid-Term elections when the public began to give up on Bush and the Reagan reconstruction. Comparatively, those divisions were not on the same scale as those the Democratic Party experienced under the Carter administration or the Republican Party experienced during the Hoover administration.

Skowronek argues that reconstructive leaders, while successful in redefining the terms and conditions of legitimate national government, have struggled like other presidents in resolving the practical problems that brought them to office:

'Jefferson's leadership left the nation weaker than it had been before in the face of the international difficulties that brought him to power; Jackson rode to power on anxieties produced by the economic dislocations of 1819 , but his alternative financial arrangements fuelled a speculative binge of their own; Lincoln's

\footnotetext{
${ }^{437}$ Stephen Skowronek, The Politics Presidents Make: Leadership from John Adams to Bill Clinton, (Cambridge: Harvard University Press, 1997), p.8.

${ }_{438}$ Stephen Skowronek, Presidential Leadership in Political Time: Reprise and Reappraisal, p.136.

${ }^{439}$ Ibid, p.138.
} 
leadership failed to end the forcible subjugation of blacks in the South and FDR's New Deal failed to pull the nation out of the Depression. ${ }^{440}$

Reagan's leadership did not solve the problems that thrust him into the presidency. Despite standing against the excesses of liberal government, he did not cancel one of the New Deal programmes. Reagan oversaw a ballooning deficit and failed in creating a smaller government. One must remember this when analysing whether Obama will be a reconstructive or pre-emptive president. He is not expected to solve all the nations' problems.

Skowronek makes a valid point when he argues that 'America's fragmented constitutional system has made sweeping political change rare and difficult to achieve. ${ }^{, 441}$ Skowronek makes a further argument when he states that over the course of history, political reconstructions have become less and less a creature of presidential will, and presidents acting within these emergent parameters should become more wary of the prospects for imposing their designs wholesale. ${ }^{442}$ Skowronek argues that, just as reconstructive leaders reconstitute the political system on the basis of wholly new commitments, pre-emptive leaders drive defenders of the system to purge them as threats to the constitutional government itself. ${ }^{443}$ Obama certainly falls into the pre-emptive category as we have witnessed the rise of the Tea Party since the election of Obama in 2008.

What we have seen from Obama's first term as president is that his achievements parallel Reagan's transformation of America and certainly he still has the opportunity to be remembered as the sixth president of reconstruction. Obama was elected at a time of the worst global financial crisis since the 1930s and America was in the midst of fighting long wars in Iraq and Afghanistan. In Skowronek's 2010 second edition book, Presidential Leadership in Political Time: Reprise and Reappraisal, he

\footnotetext{
${ }^{440}$ Ibid, p.96.

${ }^{441}$ Ibid, p.84.

${ }^{442}$ Stephen Skowronek, The Politics Presidents Make: Leadership from John Adams to Bill Clinton, p. 445 .

${ }^{443}$ Stephen Skowronek, Presidential Leadership in Political Time: Reprise and Reappraisal, p.112.
} 
poses a central question: Is Transformational Leadership Still Possible?

Skowronek poses four possible responses when seeking to analyse

Obama's place in political time, which frames the following analysis of the

Obama presidency and its ultimate trajectory.

Response 1: Transformational leadership is still possible, and Obama might yet pull it off:

Obama's first inaugural speech was aimed at a repudiation of the Reagan era, just as Reagan's first inaugural speech repudiated the New Deal and Carter presidency. Jon Johansson argues that Obama's address drew on Skowronek's connection between new commitments and old articles of faith. ${ }^{44}$ For instance Obama stated:

'At these moments, America has carried on not simply because of the skill or vision of those in high office, but because we the people have remained faithful to the ideals of our forebears and true to our founding documents. ${ }^{445}$

Obama's inaugural address also talked about reaffirming the founding principles of the Union.

'The time has come to reaffirm our enduring spirit, to choose our better history, to carry forward the precious gift, that noble idea passed from generation to generation: the God-given promise that all are created equal, all are free, and all deserve a chance to pursue their full measure of happiness. ${ }^{446}$

Obama's Inauguration would also repudiate the core of Regan's reconstruction, the idea that Government is too big.

'The question we ask today is not whether our government is too big or too small, but whether it works -- whether it helps families find jobs at a decent wage, care they can afford, a retirement that is dignified. Where the answer is yes, we intend to move forward. Where the answer is no, programs will end. And those of us who manage the public's dollars will be held to account, to spend wisely, reform bad

\footnotetext{
${ }^{444}$ Jon Johansson, 'Obama in Political Time: Presidential Leadership in the $21^{\text {st }}$ Century', Fulbright Speech.

${ }_{445}$ Barack Obama, 'First Inaugural Address', 20 January 2009, White House, http://www.whitehouse.gov/blog/inaugural-address/, (Assessed 5 March 2013).

${ }^{446}$ Ibid.
} 
habits, and do our business in the light of day, because only then can we restore the vital trust between a people and their government. ${ }^{447}$

Johansson would also argue that the 'repudiative quality of Obama's Inaugural's rhetoric was matched only by his exhortation for change, presaging a different way of conducting politics, but a politics that was still faithful to the underlying values that have always driven the American experiment. ${ }^{448}$

The most tangible evidence that so far argues for an Obama Reconstruction is the fact that he was elected by a new coalition in 2008 and was re-elected by that same coalition in 2012. While Chapter Five of this thesis deals with the specific make up of that coalition, Obama certainly has pulled together a new governing force. Following the 2012 election, Obama was asked by Time Magazine how long the new kind of governing coalition would last and whether the Reagan-era would be replaced by an Obama-era realignment. Obama stated:

'Well, look, there are a couple of forces at work here. There is the much-noted demographic shift in this society, and that obviously was reflected in this election. I think some people thought that 2008 was an anomaly; that everybody was excited about the idea of the first African American President, but once that excitement ebbed that somehow we would revert back to the old voting models. And that didn't prove to be the case, and we didn't think it was going to be the case.

It's more than just demographics, though; it's also generational. One of the things that I'm very proud of during my first four years is I think l've helped to solidify this incredibly rapid transformation in people's attitudes around LGBT issues - how we think about gays and lesbians and transgender persons. A lot of that just has to do with the fact that if you talk to Malia, the idea of making an anti-gay remark at her school is just unimaginable. They just don't get that.

And so, there are those attitudinal shifts that make up this new coalition as well. For all the divisions that you read about in our politics - and many of them are real and powerful - the truth is, is that we have steadily become a more diverse and tolerant country that embraces people's differences, and respects people who are not like us. And that's a profoundly good thing. That's one of the strengths of

\footnotetext{
${ }^{447}$ lbid.

${ }^{448}$ Jon Johansson, 'Obama in Political Time: Presidential Leadership in the $21^{\text {st }}$ Century', Fulbright Speech.
} 
America. It was hard-fought. And there's been the occasional backlash, and this is not to argue that somehow racism or sexism or homophobia are going to be eliminated or ever will be eliminated. It is to argue that our norms have changed in a way that prizes inclusion more than exclusion.

And I do think that my eight years as President, reflecting those values and giving voice to those values, helps to validate or solidify that transformation, and I think that's a good thing for the country. And, by the way, it's part of what will make America a continued leader of the 21 st century - because the world is shrinking, and one of our greatest assets is the fact that we have people from everywhere who want to come here because they know this is an open society, and they know that they will be judged more on their talents and their skills and their commitment to an ideal and a creed, as opposed to what tribe they come from or what God they worship. And that's something that we should be grateful for. ${ }^{449}$

Obama is well aware of his place in history and the fact that a new coalition elected him in 2008 and 2012 is a large part of his reconstructive potential. Obama acknowledges the fact that demographic changes helped his cause, but also argues that generational changes have also contributed to his success of an Obama led re-alignment through a changing of people's attitudes, and a renewed push towards equality.

\section{American political commentator and former advisor to Presidents Nixon, Ford, Reagan and Clinton, David Gergen argues that there is a pattern to the way presidents like Jefferson, Jackson, Lincoln, FDR and Reagan have created a new politics:}

'In each case, they came into power by knocking down an old orthodoxy and in its place built what is now popularly called "a new paradigm." Roosevelt gave the boot to laissez-faire and put government at the helm of the economy. Reagan shifted the balance away from a government-centered system and embraced an entrepreneurial culture. They also built new political movements and created cadres of loyal followers who would pick up their banner when they fell. Inevitably, they also left behind an agenda of unfinished work that subsequent presidents tried to complete. ${ }^{450}$

\footnotetext{
${ }^{449}$ Richard Stengel, Michael Scherer and Radhika Jones, 'Setting the Stage for a Second Term, Time Magazine, 19 December 2012, http://poy.time.com/2012/12/19/setting-the-stage-for-a-secondterm/\#ixzz2Fk5ZOE4E, (Assessed 20 December 2012). 450 David Gergen, Eyewitness to Power: The Essence of Leadership - Nixon to Clinton, (New York: Simon and Schuster, 2005), p.352.
} 
Gergen goes on to argue that today's politics is ripe, 'for a president to come into office and offer a new paradigm. There may not be an old orthodoxy to knock down; no single regime of ideas is now dominant. But the winds of change are blowing so hard that voters are eager to find a leader who will set forth a clear, steady path into the future. The next president who does that successfully will also be the next to have a living legacy. ${ }^{451}$ Obama has built a successful political movement and also pushed back against the Reagan paradigm with the passing of healthcare reform and the $\$ 787$ billion American Recovery and Reinvestment Act. Obama has the potential at the beginning of his second term to be what Gergen describes.

It is clear that Obama has fostered and created a new governing coalition, Obama has also managed legislative success in his first term by passing historic health care reform in 2010. Health care was established in every other industrialised country and health care reformers have historically run into bitter opposition in the United States. The Patient Care and Affordable Care Act 2010 aimed to introduce new benefits for healthcare in America. The Act expanded access to Medicaid for thirty-two million Americans who lacked insurance; by 2014 private insurers will no longer be able to avoid or cut people with "pre-existing" health conditions and the new reforms require virtually all Americans starting in 2014 to buy basic health insurance. ${ }^{452}$ Obama's healthcare reform stands alongside Reagan's tax reform as the major policy achievement for each president and, with Obama winning a second term, he has solidified his first term achievement. This will be well entrenched by the time America votes for president in 2016. Health Care reform is a goal presidents have been striving to achieve for a hundred years.

One should not overlook the $\$ 787$ billion stimulus bill that was passed in the months following the 2008 election. The passing of the stimulus bill halted America's slide into depression. The Act includes a combination of

\footnotetext{
451 Ibid.

452 Lawrence R Jacobs and Theda Skopol, Health Care reform and American Politics, p.4.
} 
tax cuts, infrastructure spending, money for antipoverty and job training, increased funding for education, clean energy and huge investments in housing and scientific research. ${ }^{453}$ The size and scope of the American Recovery and Reinvestment Act would be one of the biggest domestic initiatives since FDR's New Deal was passed in response to the Great Depression in the 1930's. Unlike FDR's New Deal, which was a number of initiatives enacted and adjusted over several years; the Recovery Act was a single piece of legislation. The Recovery Act was more than $50 \%$ bigger than the entire New Deal and twice as big as the Louisiana Purchase and Marshall Plan combined. ${ }^{454}$ The Recovery Act updated FDR's New Deal for a new era and, while the results didn't kick in overnight, independent economic forecasters all agree that the Act helped stop the economy bleeding jobs, helping avert a second depression, ending a brutal recession. ${ }^{455}$ Michael Grunwald argues,

'Critics often argue that while the New Deal left behind iconic monuments - the Hoover Dam, Skyline Drive, Fort Knox - the stimulus will leave a mundane legacy of sewage plants, repaved potholes, and state employees who would have been laid off without it. ${ }^{456}$

Obama's Recovery Act provided a down payment on his agenda of curbing fossil fuel dependence and carbon emissions, modernising healthcare and education, making the tax code more progressive and government more effective, and building a sustainable competitive twentyfirst-century economy. ${ }^{457}$ Without the Recovery Act, an estimated 3 million more people would have been made unemployed. Economists also concluded that at its height, the Recovery Act increased output by over $2 \%$, the difference between growth and contraction. ${ }^{458}$ When comparing Obama's achievements in his first term to that of Reagan's, Obama's reconstructive potential would have to be greater than that of Reagan's. Reagan's silver bullet was tax changes which led to economic growth

\footnotetext{
${ }^{453}$ Garren Dorrien, The Obama Question: A Progressive Perspective, p.3.

${ }^{454}$ Michael Grunwald, The New New Deal: The Hidden Story of Change in the Obama Era, (New York: Simon and Schuster, 2012), p.12.

${ }^{455}$ Ibid.

${ }^{456}$ lbid, p.11.

${ }^{457}$ Ibid, p.14.

458 Ibid.
} 
(albeit very unequal growth across the economy), the creation of 19 million jobs and a rhetorical transformation of the American society after more than a decade of low morale and American's believing that the nation's best days were behind them. Obama in his first term passed historic healthcare legislation which has brought about a complete reconstruction of the United States Health Care system and a Recovery Act that averted a second great depression.

As Obama embarks on his second term, further opportunities await that could further recast the political landscape in the America. Despite the ongoing gridlock in Washington, immigration reform looks to be one area that Obama will be able to make meaningful progress in his second term. Obama won the Hispanic vote convincingly in 2008 and extended that victory in 2012 after Republican challenger Mitt Romney pushed for an immigration plan forcing undocumented immigrants to self-deport. ${ }^{459}$ Following Obama's second inaugural speech, eight senators - including four from each party announced a framework for immigration reform, 'that would provide an eventual path to citizenship for most of the more than 11 million undocumented immigrants in America. ${ }^{460}$ Obama was criticised during his first term for failing to deliver on a 2008 campaign promise to make overhauling immigration policy a focus of the first term. However, in the lead-up to the 2012 election, Obama announced a halt to deportations of some 'young undocumented immigrants in a move that delighted the Latino community. ${ }^{461}$ Obama's renewed focus came into fruition on 30 January 2013 when he announced a comprehensive immigration plan in a speech to Del Sol High School in Nevada:

'America's immigration system is broken. Too many employers game the system by hiring undocumented workers and there are 11 million people living in the shadows. Neither is good for the economy or the country. It is time to act to fix the broken immigration system in a way that requires responsibility from everyone -

\footnotetext{
${ }^{459}$ Dan Lotian, Jessica Yellin and Tom Cohen, 'Now's the time to move on immigration reform,' in CNN, 29 January 2013, http://edition.cnn.com/2013/01/29/politics/immigrationreform/index.html?iref=allsearch, (Assessed 4.2.2013).

460 Ibid.

461 lbid
} 
both from the workers here illegally and those who hire them-and guarantees

that everyone is playing by the same rules. ${ }^{462}$

Obama's immigration reform plan is made up of four parts:

1. Continuing to Strengthen Border Security.

2. Cracking Down on Employers Hiring Undocumented Workers.

3. Earned Citizenship - With 11 million undocumented immigrants living in America, the proposal provides a legal way for undocumented immigrants to earn citizenship.

4. Streamlining Legal Immigration. ${ }^{463}$

Perhaps the most contentious part of Obama's plan is providing a way to citizenship for undocumented immigrants, but it is increasingly likely that a deal will be made in Congress for this to occur. Comprehensive immigration reform will sit alongside Health Care reform as the 'Change' that Obama campaigned for in 2008. If Obama's proposal is passed, then he will give millions of illegal immigrants the chance to come out from the shadows and legally contribute to the United States. Like Lincoln who freed the slaves and gave four million African American's the chance to freely live the American dream, Obama will, in the eyes of Hispanics, be their champion. He will once and for all solve the immigration debate in America, which will contribute further to a presidency that is increasingly reconstructive in nature.

Also following the 2012 election, on December 14 an armed gunman entered the Sandy Hook Elementary School in Newtown Connecticut and shot dead 27 people before turning the gun on himself. Following the shooting and the outcry, the debate on gun laws was restarted, with Obama making gun control a central issue at the start of his second term in office. Obama formed a Gun Violence Task Force to be led by Vice

\footnotetext{
${ }^{462}$ Barack Obama, 'Fixing our Broken Immigration System so Everyone Plays by the Rules,' White House, 30 January 2013, http://www.whitehouse.gov/the-press-office/2013/01/29/fact-sheet-fixingour-broken-immigration-system-so-everyone-plays-rules, (Assessed 4 February 2013).
}

${ }^{463}$ Ibid. 
President Joe Biden, to address the causes of gun violence in the USA. In January 26 2013, Obama announced his plan to reduce gun violence in America. Obama argued,

'We won't be able to stop every violent act, but if there is even one thing that we can do to prevent any of these events, we have a deep obligation, all of us, to try. ${ }^{464}$

Alongside 23 Executive Actions Obama signed into law, the plan includes:

1. Closing background check loopholes to keep guns out of dangerous hands. This includes requiring background checks for all gun sales and strengthening the existing background check system to make sure that dangerous people are prohibited from owning guns.

2. Banning military-style assault weapons and high-capacity magazines, and taking other common-sense steps to reduce gun violence. This includes reinstating the assault weapons ban that existed from 1994 to 2004; limiting ammunition magazines to 10 rounds; giving law enforcement additional tools to prevent and prosecute gun crime - such as creating serious punishments for gun trafficking; ending the freeze on gun violence research and encouraging gun owners to store guns safely.

3. Making schools safer by putting up to 1,000 more school resource officers and counsellors in schools; ensuring every school has a comprehensive emergency management plan and create a safer climate in schools across America.

4. Increasing access to mental health services by making sure students and young adults get treatment for mental health services and ensuring coverage of mental health treatment by finalising requirements for private health insurance plans to cover mental health services. ${ }^{465}$

Obama's plan was met with opposition by the NRA (National Rifle Association), but in polling, many of the proposals were strongly supported. A CNN/Time Poll taken after Obama's announcement shows that $56 \%$ of those polled favoured a ban on semi-automatic assault weapons, 69\% agreed with a requirement for all gun owners to register their firearms and an overwhelmingly high number of respondents

\footnotetext{
464 Barack Obama, 'Now is the time,' in White House, January 16 2013, http://www.whitehouse.gov/issues/preventing-gun-violence, (Assessed 4 February 2013). ${ }^{465}$ lbid.
} 
favoured background checks at all levels. Overall $55 \%$ of respondents favoured stricter gun controls, with $56 \%$ arguing that it is too easy to buy guns in America. However, only $39 \%$ of respondents agreed that stricter gun controls would reduce gun violence. ${ }^{466}$ With the right to keep and bear arms enshrined in law in the Second Amendment of the United States Constitution and firearm ownership one of the highest per capita in the world, any changes to gun laws that Obama could make would be paradigm shattering. White it won't be easy to make any meaningful changes to gun laws with the NRA leading the charge to defend the status quo, Obama has the chance to further reinforce his reconstructive potential by securing change.

While it is not clear whether Obama will be a remembered as a reconstructive president or a pre-emptive president, other reconstructive presidencies did not occur in the first term. For instance Andrew Jackson did not become a transformative president until after his re-election in 1832. In his second term Jackson was able to dismantle the second Bank of the United States, shifting politics in the party's favour for the next generation. John Balkin argues:

'Jackson's example suggests that a reconstructive Obama presidency is still possible. Obama has a remarkable record of accomplishments. The Affordable Care Act is the most important piece of domestic legislation since the 1960's. ${ }^{467}$

Obama's Health Care reform will be remembered in generations to come as a cornerstone achievement for President Obama.

Whether or not Obama will be remembered as a president of reconstruction remains to be seen, but the coalition that elected Obama, like the coalition that elected Reagan in the 1980s and that Republicans relied on until 2008 , has the ability to give Obama what he wishes to be

\footnotetext{
${ }^{466}$ CNN Political Ticker, 'CNN/Time Poll: Slight dip in support for gun control measures in last month,' in CNN, January 16 2013, http://politicalticker.blogs.cnn.com/2013/01/16/cnntime-poll-slight-dip-insupport-for-gun-control-measures-in-last-month/?iref=allsearch, (Assessed 4 February 2013). ${ }_{467}$ Jack M. Balkin, 'What it will take for Barack Obama to become the next FDR,' in The Atlantic, November 2012, www.theatlantic.com/politics/archive/2012/11/what-it-will-take-for-obama-to-becomethe-next-fdr/264195, (Assessed 21 November 2012).
} 
remembered for: a transformative figure who changed America for the better. Following the 2012 Election, Bob Moser in the American Prospect wrote:

'The right will not wither or relent in response to the message this election has delivered. But progressives can now take heart. The conservative consensus that took hold of America with Ronald Reagan's election in 1980 is over. The idea that government is the enemy no longer prevails. Obama may not have created a liberal movement - and he may not do so in the next four years. But the emerging liberal majority can. ${ }^{468}$

Moser's comment was backed up by Obama's Second Inaugural speech that he delivered on Monday 21 January 2013. Many commentators argued that Obama's speech was further evidence of the end of the Reagan era and the beginning of a more progressive era. In his address Obama said:

'We, the people, declare today that the most evident of truths -- that all of us are created equal -- is the star that guides us still; just as it guided our forebears through Seneca Falls, and Selma, and Stonewall; just as it guided all those men and women, sung and unsung, who left footprints along this great Mall, to hear a preacher say that we cannot walk alone; to hear a King proclaim that our individual freedom is inextricably bound to the freedom of every soul on Earth. ${ }^{469}$

Obama, in the footsteps of Lincoln, has staked the second term of his presidency on the creation of a more equal society:

'It is now our generation's task to carry on what those pioneers began. For our journey is not complete until our wives, our mothers and daughters can earn a living equal to their efforts. Our journey is not complete until our gay brothers and sisters are treated like anyone else under the law - for if we are truly created equal, then surely the love we commit to one another must be equal as well. Our journey is not complete until no citizen is forced to wait for hours to exercise the right to vote. Our journey is not complete until we find a better way to welcome the striving, hopeful immigrants who still see America as a land of opportunity - until bright young students and engineers are enlisted in our workforce rather than expelled from our country. Our journey is not complete until all our children, from

\footnotetext{
${ }^{468}$ Bob Moser, 'Obama wins the future,' in The American Prospect, 7 November 2012, www.propsect.org/article/obama-wins-future, (Assessed 9 November 2012).

${ }^{469}$ Barack Obama, 'Inaugural Address by President Barack Obama', in The White House, January 21 2013, http://www.whitehouse.gov/the-press-office/2013/01/21/inaugural-address-president-barackobama, (Assessed 27 January 2013).
} 
the streets of Detroit to the hills of Appalachia, to the quiet lanes of Newtown, know that they are cared for and cherished and always safe from harm. ${ }^{, 470}$

Many commentators argued that Obama's second inaugural speech was perhaps the moment that marked the end of the Reagan reconstruction and the beginning of a new 'Obama reconstruction'. Obama's second inaugural address offered the best rebuttal to Reagan's reconstruction. CNN contributor Van Jones argued:

'Like Reagan, the president sought to ground the national conversation in his own definition of patriotism. But instead of the "liberty-only" patriotism of Reagan and political descendants such as Paul Ryan, who would turn love of country into hate for its government and its people, Obama offered a deeper "liberty and justice for all" patriotism... Reagan offered up a vision of an over-taxed, long-neglected "We the People"; Obama's version of "We the People" is youthful, diverse, energetic and engaged. Both saw their addresses as a call to arms for all Americans. Both sought to tie the best traditions of our founding fathers to today's challenges. Both insisted that what truly drives America is the ingenuity and independence of our people. ${ }^{471}$

Skowronek's first response argues that the reconstructive model of transformative leadership is still possible for Obama and as his second term begins, it is still entirely possible for him to leave the legacy as a transformative figure who reconstructed the polity.

Response 2: The reconstructive model of transformational leadership may work for some future president, but it was never likely to work for Obama:

It is possible that a political reconstruction for Obama was never really likely to occur. According to Skowronek's theory it is clear that political regimes in American history have not withered and died easily, hence in more than 230 years since independence, have there been only five reconstructive presidents. Each regime has survived several rounds of opposition leadership before a new regime has taken over, 'it is hardly a surprise that each successive round of opposition leadership is a bit more

\footnotetext{
470 lbid.

${ }^{471}$ Van Jones, 'Obama speech: Anti-government era is over,' in CNN, 23 January 2013, http://edition.cnn.com/2013/01/22/opinion/jones-obama-speech/index.html?iref=storysearch, (Assessed 27 January 2013).
} 
strident in its assaults on the established regime and a bit more forthright in its quest to displace it. ${ }^{472}$ Obama is only the second opposition president to assume the office since the Reagan reconstruction and no second round opposition leader has successfully reconstructed American government and politics. ${ }^{473}$ Skowronek argues:

'Obama is the second opposition leader to come to power since the Reagan Revolution, and if his assault on the conservative regime has been more forceful and direct than Bill Clinton's, it is because the passage of time always brings the limitations and adverse consequences of received prescriptions more clearly into view. $^{474}$

Skowronek cites the examples of President Woodrow Wilson and Richard Nixon as examples similar to Obama:

'Wilson's critique of the liberal regime of the post-Civil War era was more direct and strident than Grover Cleveland's; Nixon's critique of the liberal regime of the post-New Deal era was more direct and strident than Dwight D. Eisenhower's. Moreover, Wilson and Nixon each anticipated the new coalition that would later serve to anchor a new regime. ${ }^{475}$

Obama was elected by a new coalition, a coalition with demographics that is only going to grow in size. If Skowronek's theory is correct, then Obama will be a pre-emptive president, albeit more effective and potent than that of Bill Clinton. It will also be likely under Skowronek's theory that a Republican will win the White House in 2016. It will then be highly likely that the next Republican president will also oversee a disjunctive period of political time. Once this occurs, then finally will the new democratic majority repudiate Reagan's reconstruction and bring about a complete political transformation, but only after the Republican Party has collapsed.

Skowronek touched on this by arguing that John McCain's 2008 campaign for president setup for a perfect political disjunction:

"John McCain, the self-styled "maverick" of the Republican Party, was about as clear an example as American history afford of the insider critic who offers to

\footnotetext{
472 Stephen Skowronek, Presidential Leadership in Political Time: Reprise and Reappraisal, p.177.

${ }^{473}$ Ibid.

474 Ibid.

475 Ibid.
} 
rehabilitate and repair a regime in deep trouble. McCain's message in 2008 was that the Republican Party had lost its way, that the Bush administration had made mistakes, that McCain's leadership was needed to put conservatism back on track. McCain's 2008 campaign was the perfect setup for a classic political disjunction. ${ }^{476}$

Before the 2012 election, the same was touched upon by Jack M. Balkin, who argued that as the fourth Republican president in the Reagan regime, Romney would oversee a regime in decline:

'Demographic shifts have weakened the Republican electoral coalition, while Republican politicians have grown increasingly radical and ideological. At best, Romney will be an affiliated president attempting to revive the Republican brand after it has been badly tarnished by George W. Bush; at worst, he will be a disjunctive president, unable to keep his party's factions together, and presiding over the end of the Reagan coalition. ${ }^{477}$

While Romney was ultimately unsuccessful in defeating Obama, the fact still remains that the Republican Party has become rigid, radical, and unrealistic and Balkin argues that the next Jimmy Carter, Herbert Hoover or John Quincy Adams will herald from the Republican Party. ${ }^{478}$

The 2008 election campaign was dominated by a failing economy. Obama came out in support for a financial bailout negotiated in the dying days of the Bush administration. This limited Obama's position to argue for a complete repudiation of the Bush administration and the dominant political discourse articulated by Reagan so successfully in the 1980s. Skowronek touches on this point that the Obama administration engaged from 'the get-go in stabilising the system it was repudiating rhetorically. ${ }^{, 49}$

'Candidate Obama had joined the deliberations on the bank bailout in the final days of the Bush administration, and he had lent them support. From that moment,

\footnotetext{
${ }^{476}$ Ibid, p. 179 .

477 Jack M. Balkin, 'Why the GOP should fear a Romney Presidency,' in The Atlantic, November 2012, www.theatlantic.com/politics/archive/2012/10/why-the-gop-should-fear-aromney-presidency/263918, (Assessed 21 November 2012).

478 Ibid.

${ }^{479}$ Stephen Skowronek, Presidential Leadership in Political Time: Reprise and Reappraisal, p.180.
} 
the traditional boast of the reconstruction leader - the claim that he could address the crisis with "clean hands"- was compromised. ${ }^{480}$

Obama entered office severely hamstrung by his predecessor's existing commitments in Iraq and Afghanistan. Because of this, Obama's chances of a reconstruction were already tenuous at best from the moment he won election. Jon Johansson argues:

'All these factors, when combined with Obama's economic inheritance and the flat (debt-fuelled) economy now presided over, makes Obama's political context arguably the most complex and problematic since FDR rose to the presidency during the Great Depression. ${ }^{481}$

Obama's context is probably more complex than the context that FDR inherited in the 1930s. Obama entered office not only with a failing economy in recession, but also fighting wars in Iraq and Afghanistan. FDR and Reagan were tied in no way to the governing regime they defeated on their way to victory. Unfortunately for Obama, circumstances meant this was not possible.

In a political age dominated by the other party, pre-emptive presidents must continually navigate against fierce political currents. Their political legitimacy is always in question. The regime's dominant party continually casts doubt on their right to rule, and their own party often seems too weak to defend them. Obama has often struggled against the dominant regime and one example of this was Obama's dealing with the debtceiling crisis in 2011, when Republicans threatened to default on the nation's debt unless Obama agreed to their demands of spending cuts. Johansson argues:

'Members of his own party looked on with increasing horror, Obama made concession after concession, at one point offering to cut Social Security and Medicare benefits in a grand bargain. But Republicans refused to take yes for an answer if it meant raising taxes by even a penny. At the last minute, a crisis was averted. Obama seemed politically humiliated. Yet by successfully putting off

\footnotetext{
${ }^{480}$ Ibid.

${ }^{481}$ Jon Johansson, 'Obama in Political Time: Presidential Leadership in the $21^{\text {st }}$ Century', Fulbright Speech
} 
resolution of the big issues of spending and taxes until after the 2012 election, Obama brought himself time to plot a comeback. ${ }^{482}$

Obama's strategy here was entirely consistent with his pre-emptive predecessors Clinton and Nixon.

Finally, Obama has faced stiff opposition from the Republican Party and those affiliated to the Reagan era and the attacks on his character gives further credence that he will be a pre-emptive president. Other preemptive presidents Andrew Johnson, Clinton and Nixon faced impeachment proceedings and personal attacks on their character. We have already seen attacks on Obama's character throughout his first term with attacks on whether he is even eligible to be president. Obama's citizenship was called into question by opponents such as Donald Trump, who forced Obama into releasing his Birth Certificate. Jack M. Balkin touches on this point:

'Republicans have one last card to play: impeachment. Republicans have been trying their best to find a damaging scandal during Obama's first term, so far with little success. But the longer a presidency lasts, the greater the chances are that something will turn up, especially in a president's second term. And if a scandal takes off, Republicans can try to impeach Obama. Scandal and impeachment are serious dangers for pre-emptive presidents, whose legitimacy is usually already under siege. ${ }^{483}$

If character attacks continue by those affiliated to the Reagan era, then expect impeachment proceedings to be initiated against Obama.

Opponents have already seized on Obama's handling of security in Libya after the United States ambassador was killed after the embassy was attacked.

Response 3: The reconstructive model of transformational leadership is irrelevant. It has, in effect, been superseded by more purely progressive models of reform:

\footnotetext{
482 Ibid.

483 Jack M. Balkin, 'What it will take for Barack Obama to become the next FDR,' in The Atlantic, November 2012, www.theatlantic.com/politics/archive/2012/11/what-it-will-take-for-obama-to-becomethe-next-fdr/264195, (Assessed 21 November 2012).
} 
The modern presidency exists in a highly sophisticated and complex constitutional and institutional environment, embedded in an entropic system that has, over time, become more and more change-resistant. ${ }^{484}$ When analysing the reconstructive presidents under Skowronek's prism, previous reconstructions were more structural in nature, changing the fabric of American government and society. Reagan's reconstruction was more superficial, as discussed, rather than bringing about wholesale structural change of the polity. Skowronek's hypothesis that the nature of reconstruction has been replaced by a more progressive form of politics certainly has merit.

Academic Matthew Laing has analysed Skowronek's hypothesis on the waning of political time and argues that 'the rise of new media, interest groups, watchdogs, and pressure organisations has expanded the size and complexity of the polity over which a president must exercise authority. ${ }^{485}$ Because of this, American democracy has grown over time and today includes more political identities and interests than ever:

'New layers of political cleavage, along ethnic, gender, and religious lines, have appeared that complicate the national political picture. In the past, a reconstructive president needed only to win over parties, elections, and legislatures. These mainstays of representative democracy have been supplemented by organisations, such as media corporations and interest groups, which exist underneath and beyond government institutions. ${ }^{486}$

The new layers of the American democracy have made it more difficult for presidents who wish to reconstruct politics to muster sufficient authority. Compared to Obama, Andrew Jackson for instance had a relatively easy job galvanising support behind his vision. The reason for this was the 'limited voting franchise, low political consciousness, party control of news media, and the paucity of non-party political organisations. His appeals to the public and enunciation of new principles and ideas facilitated the rise

\footnotetext{
${ }^{484}$ Jon Johansson, 'Obama in Political Time: Presidential Leadership in the $21^{\text {st }}$ Century', Fulbright Speech

${ }^{485}$ Matthew Laing, 'Towards a Pragmatic Presidency? Exploring the Waning of Political Time,' in Polity, Volume 44, Number 2, April 2012, p. 241.

${ }^{486}$ Ibid.
} 
of a new set of political cleavages in the United States. ${ }^{487}$ While Jackson's ideas only had to resonate with white middle-lass men, as more and more constituencies have been enfranchised, it has been harder to build and sustain viable coalitions. ${ }^{488}$ Mary Stuckey states:

'The process of forging a single national voice capable of uniting enough of the public to earn a victory in the Electoral College has become increasingly difficult, and is likely to become more so. ${ }^{489}$

The rise of the mass media has also complicated and diminished the chances of a political reconstruction. It has also changed the way Americans interact with national politics, as Laing argues:

'So-called "narrowcasting" in which the news media becomes increasingly specialised and targets specific audiences, both reinforces social and political niches and creates new ones. The multiple social cleavages become selfreinforcing as political communication becomes self-confirming and insular. ${ }^{490}$

There has been a shift from information gathering to sensationalist stories and news entertainment. Empirical analyses of presidential rhetoric have shown that the president's ability to reach the population through the media has declined in recent decades, and that, in turn, has diminished the president's capacity to set the public agenda. ${ }^{491}$ Overall, Reagan's reconstruction was shallower compared to Lincoln, Jackson and Jefferson. One reason for this is that Reagan as well as Obama deal with a 24 hour mass media and blogs that are increasingly fragmented and partisan with their own set of agendas.

The development of the American state over more than 200 years has made the task of a reconstructive president more difficult. Today 'a president must contend with the public's declining faith in government, with increasing competition from opinion makers outside government circles, and with an endlessly growing and fracturing electorate. Moving

\footnotetext{
${ }^{487}$ Ibid.

${ }^{488}$ Ibid, p.242.

${ }^{489}$ Mary Stuckey, 'The Presidency and Political Leadership,' in Rhetoric and Public Affairs, Volume 3, Fall 2000, p. 452.

${ }^{490}$ Matthew Laing, 'Towards a Pragmatic Presidency? Exploring the Waning of Political Time,' Polity, p.242.

${ }^{491}$ Ibid.
} 
the nation's political discourse and creating a new set of policy debates across the electorate become increasingly difficult as constituencies, interests, and political cleavages increase. It seems likely that over time, any shift in the axis of partisan cleavage will be slower, less enduring, and less common than before. ${ }^{492}$ Ultimately Obama's reconstruction will be different to that of Jefferson, Jackson and Lincoln, but none the less it is still a reconstruction and just as potent.

Response 4: The reconstructive model of political transformation is still operative but only for the American Right:

The Reagan reconstruction came from the American right and Skowronek's fourth response would seem the most unlikely. Skowronek argues:

'Nothing in our history suggests that reconstruction must come from an ideological position polar opposite to that which animated the one immediately prior. Jackson drove a second, more thoroughgoing reconstruction in the spirit of Jefferson's, and FDR's deepened the progressivism implicit in Lincoln's. ${ }^{493}$

Reagan's reconstruction repaired the clarity and simplicity of the Constitution after Lincoln and FDR introduced new and complicating elements into the politics of reconstruction: ${ }^{494}$

'Reagan enlisted the Constitution's Framers as libertarians to renounce federal aggrandisement and the tyranny of the welfare state. He stigmatised the realist's faith in in a "living" constitution as a disastrous corruption of standards; his substitutes were originalism and idealism. ${ }^{495}$

Skowronek further describes Reagan's reconstruction as being suggestive of this potential and Reagan's reconstruction has proved to be the most shallow of all the reconstructive presidencies so far.

'Reagan did not actually dismantle any liberal program of significance, nor did he dislodge any institution vital to the support of progressive government. This

\footnotetext{
492 Ibid, p.243.

493 Stephen Skowronek, Presidential Leadership in Political Time: Reprise and Reappraisal, p.188.

494 lbid, p. 187.

495 lbid, p. 188.
} 
reconstruction proved to be shallower even than Roosevelt's. It was more rhetorical and political than institutional and governmental. Beneath the rhetoric was no small dose of pragmatic action. ${ }^{, 496}$

Because of Reagan's inability to dismantle or fundamentally change the structure of FDR's New Deal, Skowronek's theory argues that the conservative reconstruction has not yet reached fruition.

Following the 2008 election, on February 19 2009, CNBC commentator Rick Santelli delivered a dramatic and powerful repudiation of Obama's administration shoring up of the plunging housing market. 'Invoking the Founding Fathers and ridiculing "losers" who couldn't pay their mortgages, Santelli called for Tea Party protests. ${ }^{497}$ Over the next two years the Tea Party movement took off. At a grass roots level, Tea Party organisations sprung up all over America, raising money and supporting candidates. Their goals are tax cuts for the wealthy, deregulation of business, and the privatisation of Social Security and Medicare. The Tea Party are united in their opposition to Obama, who they label a Socialist and their desire to extend and complete the Reagan revolution and push the Republican Party to the right. ${ }^{498}$

Skowronek argues that another conservative-led reconstruction cannot be ruled out with the global financial recession and the advent of the Tea Party movement:

'With the Republican Party prodded on by the Tea Party movement, the prospect cannot be ruled out that Obama's presidency will serve to propel the conservative movement forward toward a final, more decisive rout for the progressive alternative. A passing thunder on the left might just be the thing to catalyse a second and more thoroughgoing reconstruction from the right. ${ }^{499}$

While the Tea Party made headlines in the 2010 mid-term elections, the headlines were not all positive. Despite the negative publicity the Tea

\footnotetext{
${ }^{496}$ Ibid, p.188-189.

497 Theda Skocpol and Vanessa Williamson, The Tea Party and the Remaking of Republican Conservatism, (New York: Oxford University Press, 2012), p.7.

${ }^{498}$ Ibid, p.5.

${ }^{499}$ Stephen Skowronek, Presidential Leadership in Political Time: Reprise and Reappraisal, p.188.
} 
Party has faced, it has not stopped supporters going on the offence to criticise Obama:

'Though the nation's agenda has been bound by decades by conservative priorities, they have never completely relinquished their reconstructive posture, and the Obama administration has given them plenty with which to revive its latent potential. 500

Despite the prevalence of the conservative agenda, Skowronek makes another pertinent point regarding the conservative's reconstructive vision:

'The reconstructive stance in conservative rhetoric is sharpened both by its categorical rejection of progressivism as a corruption of the original Constitution and by its appeal back to a limited government that maximises individual liberty. But there is nothing, either in history or in modern social reality, to suggest that such an alternative could actually be implemented. ${ }^{501}$

While a small government that maximises liberty and freedom may have great rhetorical appeal in America, something that Regan took advantage of, it is a purely theoretical proposition without precedent in an advanced democracy with divergent interests. Skowronek concludes,

'It is not clear how a more thoroughgoing pursuit of the conservative project could, as a practical matter, reconcile and manage the demands now routinely placed on the American state. ${ }^{502}$

The Tea Party has been influential in boosting the Republican Party following the 2008 election. But it has not all been positive for the Republican Party, as Theda Skocpol and Vanessa Williamson argue:

'For the Republican Party, the Tea Party cuts both ways. Certainly, its enthusiasm and resources fuel the GOP. But the story is more complex because the Tea Party is not just a booster organisation for Any-Old-Republicans. Tea Party activists at the grass roots and the right-wing advocates roving the national landscape with billionaire backing have designs on the Republican Party. They want to remake it into much more uncompromising and ideologically principled force. ${ }^{.503}$

\footnotetext{
500 lbid, p.189.

501 lbid, pp.189-190.

502 lbid, p. 190.

503 Theda Skocpol and Vanessa Williamson, The Tea Party and the Remaking of Republican Conservatism, p.155.
} 
As the Tea Party make inroads into the Republican Party, they push it further and further to the right which only appeals to an older, white vote. Because of the drive for ideological purity, the Republican chance of retaking the White House actually diminishes.

Overall, Skocpol and Williamson argue that the Tea Party has pulled the Republican Party sharply toward the right, and 'shifted US public debates at a crucial juncture, blunting the reformist force of Barack Obama. ${ }^{, 504}$ When looking forward, perhaps Senate Majority leader, Harry Reid's argument that, the Tea Party will disappear as soon as the economy gets better, is correct. ${ }^{505}$ Not only will the Tea Party's argument diminish when the economy improves, Tea Party candidates extreme and uncompromising position on abortion has also meant the Republican Party has failed to capitalise and win several key Senate races. Because of the Tea Party it can be argued that the Democratic Party has held onto the Senate in difficult electoral circumstances in 2010 and 2012. Out of the four options that Skowronek identifies, this would have to be the least likely to occur.

\section{A Pre-emptive or Reconstructive president? - Obama's future prospects} at the beginning of his second term.

Skowronek makes an interesting point when he states:

'The typology is not rigidly deterministic in the sense that every candidate is pegged in one box or another from the get-go; it is, rather, an interactive set of political relationships framing problems and probabilities as they have been manifested historically. Presidents tend to play at the margins of these types. They seek to solve the problems presented by these situations, to test the possibilities and stretch for new resolutions. ${ }^{, 506}$

At the beginning of Obama's second term, there is no definitive answer as to whether Obama will end up being remembered as a pre-emptive or reconstructive president. However, when comparing the reconstruction of

\footnotetext{
504 Ibid, p.205.

505 Ibid, p. 189

506 Stephen Skowronek, Presidential Leadership in Political Time: Reprise and Reappraisal, p.167.
} 
Reagan to Obama, no one can doubt that, like Reagan, Obama has created a new governing coalition. Obama has also passed historic healthcare reform, a reform that presidents have been seeking to pass for a century, and he prevented American economy sliding into a depression in 2009. Obama would also save the United States Auto Industry and slowly but surely the American economy is starting to grow again and unemployment is beginning to drop. Obama entered the White House with America's reputation around the world at its lowest point since the Vietnam War. Obama has concluded the war in Iraq and also has an exit strategy to draw down combat troops in Afghanistan by 2014. America's reputation around the world today is improving, and the world, once again looks to America to lead. While the threat of terrorism can never be ruled out, Obama, with the killing of Osama Bin Laden and the targeting of other Al Qaeda leaders, has severely restricted their operations around the world.

Obama's presidency in this regard is just as reconstructive as Reagan's, but due to the nature and age of the political system, there is not the same potential as Jefferson, Jackson and Lincoln, had to change the structure of government. Skowronek is correct in his third response that the nature of political reconstruction has certainly changed since the early presidents managed to reconstruct and change the very structure of democracy in the Union. However, Obama stands out above the other presidents of reconstruction for another reason, as he was the first African-American elected to the presidency and in one hundred years from now, the 2008 Presidential election and election of Obama will stand out like a beacon of light, in the progress of America and the progress to form a more perfect union. The partisan bickering and petty squabbles will be forgotten and Obama will be remembered for steering America through a great recession, extracting his country out of two wars, and for passing historic healthcare reforms - reforms that will help create a fairer America.

At the beginning of the second term, Obama has further options to cement his transformative potential. Through immigration reform and gun control 
reform, Obama can change the nature of debate in Washington and move forward to find solutions to the nation's problems. Obama's second term, beginning with his second inaugural address has signalled and cemented a rhetorical change in America, with a renewed focus on equality for all. The new progressive coalition is cementing a new norm in Washington, despite at time of fierce partisanship by elements of the Republican Party.

As the first African-American elected president, Obama's presidency was already full of potent symbolism. Millions of Americans voted for the first time, with the highest turnout in the 2008 election for decades. With Obama as their torch bearer, African American and minorities had found their voice. This in itself is reconstructive, as millions of minorities in America have the example of Obama to follow: that they too have the potential to one day become president of the United States. Like Reagan, Obama has given millions of Americans hope that the nation's best days are ahead of them and with one statement he symbolised this potential: 'Yes We Can!' The optimist in me certainly believes that Obama will be remembered in twenty years' time, as the sixth president of reconstruction according to Skowronek's recurring model of presidential authority. 


\section{Chapter Seven: The great experiment moving forward}

'Tonight, more than 200 years after a former colony won the right to determine its own destiny, the task of perfecting our union moves forward. It moves forward because of you. It moves forward because you reaffirmed the spirit that has triumphed over war and depression; the spirit that has lifted this country from the depths from despair to the great heights of hope - the belief that while each of us will pursue our own individual dreams, we are an American family, and we rise or fall together, as one nation, and as one people. ${ }^{507}$

President Barack Obama, 2012 Election night address

In conclusion, presidential leadership scholar Stephen Skowronek has largely been successful in devising a prism in which to understand presidential leadership, for to understand the modern presidency we first must understand parallels of the historic presidency. ${ }^{508}$ Although one must be careful not to make sweeping generalisations and assumptions when grouping presidents, it is clear that no matter how you do categorise them, there can be no doubt that presidents disrupt the political system around them. Their challenge is to justify that disruption and the change it brings. In one way or another, each incumbent must speak in a timely fashion to the state of the federal government's basic commitments of ideology and interest and suggest how proposed actions will bear on them. Presidents will face different challenges in doing this, insofar as each confronts pressure on those commitments from events, from the passage of time, and from the impact of prior leadership efforts. ${ }^{509}$ According to Skowronek, the president who forms an enduring governing coalition has more in common with the founder of earlier coalitions than with other presidents of his own era. For example, FDR has more in common with

\footnotetext{
${ }^{507}$ Barack Obama, 'Remarks by the President on Election Night,' 7 November 2012, www.whitehouse.govt/the-press-office/2012/11/07/remarks-president-election-night, (Assessed 9.11.2012).

${ }^{508}$ Peri E. Arnold, 'Determinism and Contingency in Skowronek's Political Time', Polity, Vol. 27, No. 3, 1995, pp.497.

${ }^{509}$ Stephen Skowronek, Presidential Leadership in Political Time: Reprise and Reappraisal,), p.83.
} 
Andrew Jackson and Ronald Reagan, compared to Harry Truman or Dwight Eisenhower. ${ }^{510}$ Skowronek's recurring model of presidential authority is the clearest model that has been developed to date where a president from the twentieth century can be accurately compared to a president from the nineteenth century; and when comparing two or more presidents a model must be used that enables one to sweep across political time. However, one must be cautious, as there is potential danger in setting aside specific events drawn from the 237 year history of the United States to force leaders into distinct boxes, from which they and we cannot escape.

Obama and Reagan were both elected to the presidency in uncertain times, in not only America, but around the world. In 1980 Reagan successfully repudiated the presidency of Carter and had framed him as someone ineffective to deal with America's problems. Obama in 2008 replaced a president who had put Americans into war in both Iraq and Afghanistan and George W. Bush had no exit strategy for American troops. By the 2008 election, the American economy was on life support, with major banking institutions failing and the American motor industry on the brink of collapse. Also in 2008, as in 1980, American's reputation around the world was at an all-time low. Like Reagan, Obama brought hope and change to the White House. While Reagan's catch cry was 'Morning in America,' Obama's message of 'Hope and Change,' was all about creating a new trajectory for America. Both presidents were able to pass major legislation and both were elected and re-elected by a new governing coalition. While both presidents made mistakes and have regrets, no one can doubt that the nature of the debate changed in Washington during their presidency. Because of these two presidents, American politics has evolved for the better - despite both being from different sides of the political spectrum.

While it is still too early to definitively conclude whether history will remember Barack Obama as a reconstructive leader or a preemptive

${ }^{510}$ Ibid. 
leader, it is my belief that Obama, like Reagan, brought a message of change to Washington. Also, like Reagan, Obama was able to bring together a new electoral coalition that saw him win the presidency in 2008 and win re-election in 2012. The coalition made of up Hispanics, African Americans, women and the young is unlike any coalition previously aligned to elect a president in United States history. While it is too early to conclude whether Obama has managed to create an enduring governing coalition, his ability to construct and maintain this electoral coalition throughout his turbulent first term is reconstructive in itself. There are promising signs for advocates of an Obama reconstruction with upwards of 80,000 Obama supporters stating that they are willing to run for public office because of Obama's presidency. ${ }^{511}$ Even if only a small fraction to these supporters decide to run and make it to public office it will be because of Obama's example, just as many conservatives in public office cite Reagan as the reason why they entered public office. Those candidates will be in office to defend and extend Obama's record for many years to come - that in itself is highly reconstructive.

The election of Barack Obama as the first African-American president was historic and that alone will go down in history as a transformational event that made millions of Americans believe that one day they too could achieve the impossible and lead the most powerful country in the world. Obama will face many new challenges over the next four years which will be centered on domestic issues. By 2016, the American economy is expected to be in better shape. Obama must work to create jobs and improve the deficit and ultimately create a stronger economy to help ensure another Democrat wins the White House in 2016, if he wants to further consolidate hi immediate legacy. Pre-emptive presidents usually aren't succeeded by members of their own party, but reconstructive presidents often are. If another Democrat can win the White House and take the oath of office in January 2017 , that will be the strongest indication that, at least for the Democrats, it is 'morning again' in America. The Age

\footnotetext{
${ }^{511}$ Michael Scherer, '2012 Person of the Year: Barack Obama, the President, Time Magazine, 19 December 2012, www.poy.time.com/2012/12/19/person-of-the-year-barack-obama, (Assessed 20 December 2012).
} 
of Reagan will be over, and the Age of Obama will have begun. ${ }^{512}$ Obama has four years to make that happen and if he can secure comprehensive immigration reform, Obama's achievements will outshine Reagan's achievements and surely the torch will be passed to the age of Obama.

Joe Klein in Time Magazine argues that Obama's second inaugural has brought about the end of the Reagan era:

'The speech confirmed the November results: that a political party tethered to a white, regional, rural base no longer has the electoral firepower to govern the country...The President has demonstrated in recent weeks that he now has a working majority in the House of Representatives for many of his initiatives. Tax rates have been increased with Republican votes, for the first time in 20 years. Hurricane relief for the Northeast was passed with a majority of Democrats and a minority of Republicans. The debt-ceiling gimmick has been postponed, and perhaps shelved, by Republican leaders who see the handwriting on the wall. Gun control will be a difficult achievement, as the National Rifle Association sways a great many Democratic legislators, but immigration reform is likely to pass with a similar bipartisan majority--Democrats plus a wise minority of Republicans--as the tax increases did. ${ }^{513}$

As the second term for Obama begins, it is clear that Obama has now woven equality into the United States social fabric with a renewed focus on equal rights for the gay community:

'The Reagan reaction to the events of the 1960s had come to an end. The welfare state would not be repealed. And while the fate of some social issues, like abortion rights and affirmative action, remains in doubt, equality has now been woven into the national fabric. ${ }^{.514}$

When analysing Obama's presidency against the set of criteria that Skowronek identified for a political transformation of American politics and society, it seems that Obama is well on his way to achieving that transformation. New Interests have secured a grip on power and that will be solidified with a Democratic victory in 2016 . The Republicans have

\footnotetext{
512 Jack M. Balkin, 'What it will take for Barack Obama to become the next FDR,' in The Atlantic, November 2012, www.theatlantic.com/politics/archive/2012/11/what-it-will-take-for-obama-to-becomethe-next-fdr/264195, (Assessed 21 November 2012).

${ }^{513}$ Joe Klein, 'The Ice is Breaking', in Time Magazine, 4 February 2013, http://www.time.com/time/magazine/article/0,9171,2134496,00.html, (Assessed 5 February 2013). ${ }^{514}$ Ibid.
} 
even abandoned their veto on tax rises. If Obama's second term can escape the major sorts of scandal that hamstrung Clinton's second term in the late 1990s, then Obama and his progressive coalition will endure and Obama will likely be remembered as the sixth president of reconstruction.

While the optimist in me sees a path to an Obama reconstruction, there is still a possibility that Obama will be classified as a pre-emptive president. When Obama entered the White House in 2009 he was not able to fully repudiate the Reagan era. Obama inherited wars in Iraq and Afghanistan and as stated earlier, his reconstructive potential was also diminished on the economic front when he came out in support for a financial bailout negotiated in the dying days of the Bush administration. This limited Obama's position to argue for a complete repudiation of the Bush administration and the dominant political discourse articulated by Reagan so successfully in the 1980 s. ${ }^{515}$ According to Skowronek's theory, Obama is only the second opposition president to assume the office since the Reagan reconstruction and no second round opposition leader has successfully reconstructed American government and politics. ${ }^{516}$

Finally, perhaps the most potent legacy of the Obama presidency, which cannot be disputed, is that in ten years' time, many Americans will not remember what the unemployment rate was when Obama assumed office or what it was when he left. The partisan bickering that dominated for much of Obama's first term will have faded into memory, but what will shine through from the Obama presidency is opportunity. Americans will never forget how Obama 'changed the limits of possibility for generations to come. ${ }^{517}$ Today there are ten year old African-American, Hispanic and Asian-American children all over the United States who believe, that because of the Obama presidency, they too can become president one day. That in itself is hugely reconstructive and by being elected President, Obama has achieved something more potent than any other

\footnotetext{
${ }^{515}$ Stephen Skowronek, Presidential Leadership in Political Time: Reprise and Reappraisal, p.180.

${ }^{516}$ Ibid, p.177.

${ }^{517}$ Liz Granderson, 'How Obama made opportunity real in America', in CNN, 21 January 2013, www.edition.cnn.com/2013/01/21/opinion/granderson-obama-change/index.html, (Assessed 24 January 2013).
} 
reconstructive presidents could have ever achieved. By forging his path, he has completed Lincoln's. 


\section{Bibliography}

Abbott, P. (2004). Borges's Encyclopedia and Classification in Presidential Studies. Presidential Studies Quarterly, 34(4), 709-731.

ABC News. (n.d.). End of Presidency Approval Rating. Retrieved April 22, 2012, from ABC News: http://abcnews.go.com/sections/politics/DailyNews/poll_clintonlegacy010117.html

Abdullah, H. (2012, October 30). Looking presidential: The optics of leadership during a disaster. Retrieved November 14, 2012, from CNN:

http://edition.cnn.com/2012/10/29/politics/looking-presidential/index.html?iref=allsearch

Abdullah, H. (2012, September 18). Secretly taped comments put Romeny back on defence. Retrieved November 14, 2012, from CNN: http://edition.cnn.com/2012/09/18/politics/romneyfallout/index.html?iref=allsearch

Abdullah, H. (2012, November 10). With their big political win, the new American electorate has arrived. Retrieved November 11, 2012, from CNN: http://edition.cnn.com/2012/11/09/politics/demographic-politicalpower/index.html?iref=allsearch

Aberbach, J. D., \& Rockman, B. A. (December 1999). Hard Times for Presidential Leadership? (And How Would We Know?). Presidential Studies Quarterly, 29(4), 757-777.

Abraham Lincoln Online. (n.d.). Gettysburg Address. Retrieved February 27, 2013, from Abraham Lincoln Online - Speeches and Writings:

http://www.abrahamlincolnonline.org/lincoln/speeches/gettysburg.htm

Acosta, J. (2012, July 26). Romney's Olympics false start. Retrieved November 14, 2012, from CNN: http://politicalticker.blogs.cnn.com/2012/07/26/romneys-olympics-falsestart/?iref=allsearch

Acosta, J. (2012, July 31). Was Romney's trip 'a great success' or gaffe-filled disaster? Retrieved November 14, 2012, from CNN: http://edition.cnn.com/2012/07/31/politics/romney-tripsuccess-disaster/index.html?iref=allsearch

Alter, J. (2010). The Promise: President Obama Year One. London: Simon \& Schuster.

Arnold, P. E. (Spring 1995). Determinism and Contingency in Skowronek's Political Time. Polity, 27(3), 497-508.

Avlon, J. (2012, November 13). Election a call for purple politics. Retrieved November 20, 2012, from CNN: http://edition.cnn.com/2012/11/12/opinion/avlon-politicalmoderation/index.html?iref=allsearch

Babay, E. (2011, May 2). Crowds Rejoice at White House after news of Bin Laden's death. Retrieved April 28, 2012, from Washington Examiner:

http://washingtonexaminer.com/local/dc/2011/05/crowds-rejoice-white-house-after-newsbin-ladens-death/113539 
Baker, P. (2012, November 7). Obama Wins a Clear Victory, but Balance of Power is Unchanged in Washington. Retrieved November 9, 2012, from The New York Times:

http://www.nytimes.com/2012/11/08/us/politics/a-divided-nation-keeps-the-statusquo.html?_r=0

Balkin, J. M. (2012, November 1). What it will take for Barack Obama to become the next FDR.

Retrieved November 21, 2012, from The Atlantic:

http://www.theatlantic.com/politics/archive/2012/11/what-it-will-take-for-barack-obamato-become-the-next-fdr/264195/

Balkin, J. M. (2012, October 24). Why the GOP should fear a Romney Presidency. Retrieved November 21, 2012, from The Atlantic:

http://www.theatlantic.com/politics/archive/2012/10/why-the-gop-should-fear-a-romneypresidency/263918/

Barabak, M. (2011, September 9). Reagan takes on mythological status. The Dominion Post, p. B2.

Barack Obama Timeline. (2008, December). Barack Obama Timeline. Retrieved February 23, 2012, from Barack Obama Timeline: http://barack-obama-timeline.com/

Barber, J. D. (2009). The Presidential Character: Predicting Performance in the White House Fourth Edition. New York : Pearson Longman.

Beland, D., \& Waddan, A. (2006). The Social Policies Presidents Make: Pre-Emptive Leadership under Nixon and Clinton. Political Studies, 54, 65-83.

Benedetto, R. (2011, January 20). Reagan and Obama - Comparing Two Presidents. Retrieved May 27, 2011, from Fox News: www.foxnews.com/opinion/2011/01/20/reagan-obama-talepresidents

Benedetto, R. (2011, January 20). Reagan and Obama - Comparing Two Presidents. Retrieved May 27, 2011, from Fox News: http://www.foxnews.com/opinion/2011/01/20/reagan-obamatale-presidents/

Bennett, W. J. (2012, November 14). Republicans lost the culture war. Retrieved November 20, 2012, from CNN: http://edition.cnn.com/2012/11/14/opinion/bennett-gopelection/index.html?iref=allsearch

Berry, M. F., \& Gottheimer, J. (2010). Power in Words: The Stories Behing Barack Obama's Speeches, From the State House to the White House. Boston: Beacon Press.

Bevan, T., \& Cannon, C. M. (2012, November 7). 21 Reasons for Obama's Victory and Romney's Defeat. Retrieved November 9, 2012, from Real Clear Politics: http://www.realclearpolitics.com/articles/2012/11/07/21_reasons_for_obamas_victory_an d_romneys_defeat_116090.html

Blackmon, D. A. (2012, November 25). Republicans face unexpected challenges in coastal South amid shrinking white vote. Retrieved November 26, 2012, from The Washington Post: http://www.washingtonpost.com/politics/republicans-face-unexpected-challenges-in- 
coastal-south-amid-shrinking-white-vote/2012/11/23/02cbda58-336a-11e2-bb9b288a310849ee_story.html

Blackmon, D. A. (2012, November 25). Republicans face unexpected challenges in coastal South amid shrinking white vote. Retrieved November 26, 2012, from The Washington Post: http://articles.washingtonpost.com/2012-11-24/politics/35511999_1_white-studentswhite-voters-black-voters

Bosch, A. (200). Reagan An American Story. New York: TV Books.

Brinkley ed., D. (2007). The Reagan Diaries. New York: HarperCollins.

Broder, D. S. (1984, October 22). Enounter Leaves Reagan on Course. The Washington Post, p. 1.

Brown, L. (1993). The New Shorter Oxford English Dictionary on Historical Principles. Oxford: Clarendon Press.

Bruce, M. (2012, March 3). Obama's Weekly Address: Defending the auto bailout. Retrieved April 28, 2012, from ABC News: http://abcnews.go.com/blogs/politics/2012/03/0bamas-weeklyaddress-defending-the-auto-bailout/

Burns, J. M. (1978). Leadership. New York: Harper and Row.

Burns, J. M. (2003). Transforming Leadership. New York: Grove Press.

Burns, J. M. (2006). Running Alone: Presidential Leadership JFK to Bush II. New York: Basic Books.

Busch, A. E. (2005). Reagan's Victory: The Presidential Election of 1980 and the Rise of the Right. Lawrence: Kansas University Press.

Caesar, J. W., Busch, A. E., \& Pitney Jr,, J. J. (2011). Epic Journey: The 2008 Elections and American Politics Post 2010 Election Update. Plymouth: Rowman \& Littlefield.

Cannon, L. (2000). President Reagan: The Role of a Lifetime. New York: BBS Books.

Carville, J. (2009). 40 More Years: How the Democrats will rule the Next Generation. New York: Simon \& Schuster.

Carville, J. (2012, November 10). Carville: GOP routed by reality. Retrieved November 12, 2012, from CNN: http://edition.cnn.com/2012/11/09/opinion/carville-buckwalter-pozaelection/index.html?iref=allsearch

CNN. (2012, November 7). 2012 Exit Poll Results. Retrieved November 17, 2012, from CNN: http://edition.cnn.com/election/2012/results/race/president

CNN. (2012, September 19). Romney doesn't back away from message caught on secret tape. Retrieved November 14, 2012, from CNN: www.edition.cnn.com/2012/69/18/politics/campaign-wrap/index.html

CNN Political Ticker. (2013, January 16). CNN. Retrieved February 4, 2013, from CNN/Time Poll: Slight dip in support for gun control measures in last month: 
ttp://politicalticker.blogs.cnn.com/2013/01/16/cnntime-poll-slight-dip-in-support-for-guncontrol-measures-in-last-month/?iref=allsearch

Cohen, T. (2012, October 23). It all shows: debates do matter in 2012. Retrieved November 11, 2012, from CNN: http://edition.cnn.com/2012/10/23/politics/debatesmatter/index.html?iref=allsearch

Cohen, T. (2013, January 21). Obama's speech ties current issues to founding principles. Retrieved January 22, 2013, from CNN: http://edition.cnn.com/2013/01/21/politics/obamainauguration-speech/index.html?iref=allsearch

Cohen, T., \& Mears, B. (2012, June 29). Emotions high after Supreme Court upholds healthcare law. Retrieved October 26, 2012, from CNN: www.cnn.com/2012/06/28/politics/supreme-courthealth-ruling/index/htm

Commission on Presidential Debates. (2009). October 21, 1984 Debate Transcript: The ReaganMondale Presidential Debate. Retrieved March 6, 2012, from Commission on Presidential Debates: http://www.debates.org/index.php?page=october-21-1984-debate-transcript.html

Commission on Presidential Debates. (n.d.). October 28, 1980, Debate Transcript: The Carter-Reagan Presidential Debate. Retrieved March 6, 2012, from Commission on Presidential Debates: http://www.debates.org/index.php?page=october-28-1980-debate-transcript

Crockett, D. A. (2000). The President as Opposition Leader. Presidential Studies Quarterly, 30(2), 245274.

Crowley, C. (2012, October 29). Crowley: Sandy introduces big unknown into campaign. Retrieved November 14, 2012, from CNN: http://edition.cnn.com/2012/10/29/politics/crowley-sandypolitics/index.html?iref=allsearch

Daily Telegraph. (2011, May 2). Osama Bin Laden Killed: Barack Obama Speech in Full. Retrieved April 28, 2012, from Daily Telegraph: http://www.telegraph.co.uk/news/worldnews/barackobama/8487354/Osama-bin-Ladenkilled-Barack-Obamas-speech-in-full.html

Dickinson, M. J. (December 2009). We All Want a Revolution: Neustadt, New Institutionalism, and the Future of Presidency Research. Presidential Studies Quarterly, 39(4), 736-770.

Dorrien, G. (2012). The Obama Question: A Progressive Perspective. Lanham, Maryland: Rowman \& Littlefield.

D'Souza, D. (1999). Ronald Reagan: How an Ordinary Man became an Extraordinary Leader. New York: Touchstone.

Duffy, M., \& Scherer, M. (2011, January 27). The Role Model: What Obama sees in Reagan. Retrieved May 27, 2011, from Time: www.time.com/time/politics/article/0,8599,2044579,00.html

Edwards III, G. C. (January 2004). In Memoriam: Richard E. Neustadt. PS: Political Science and Politics, 37(1), 125-127. 
Eisenhower, D. (2008). Leadership Quotes. Retrieved April 4, 2012, from Motivating Quotes: www.motivatingquotes.com/leadership.htm

Ellington, L. (n.d.). Presidential Power and the Modern Presidents - by Richard Neustadt. Retrieved March 14, 2012, from Regis University: http://academic.regis.edu/jriley/414\%20Power\%20to\%20Persuade.htm

Fahrenthold, D. A., \& Wilgoren, D. (2013, January 22). Obama calls for greater equality for all. Retrieved January 22, 2013, from The Washington Post: http://www.washingtonpost.com/national/inauguration/2013-inauguration-waitingwatching-bearing-witness/2013/01/21/7bc849ce-63b6-11e2-b84d21c7b65985ee_story.html

Fahrenthold, D., \& Wilgorer, D. (2012, January 20). Santorum finished 34 votes ahead of Romney in new lowa tally. Retrieved November 23, 2012, from Washington Post:

www.washingtonpost.com/politics/report-santorum-finished-34-votes-ahead-of-romney-innew-iowa-tally-votes-from-8-precincts-missing/2012/01/19.html

Fox, L. (2011, December 3). Herman Cain Drops ouf of Race for President. Retrieved November 23, 2012, from US News: www.usnews.com/news/articles/2011/12/03/herman-cain-drops-outof-race-for-presidency

Frank, J. A. (2011). Obama on the Couch: Inside the Mind of the President. New York: Free Press.

Friedman, T. L. (2012, November 7). Hope and Change: Part 2. Retrieved November 9, 2012, from The New York Times: http://www.nytimes.com/2012/11/07/opinion/friedman-hope-andchange-part-two.html

Gergen, D. (2012, April 28). What's wrong with American Politics. Retrieved April 29, 2012, from CNN: http://edition.cnn.com/2012/04/27/opinion/gergen-polarizedpolitics/index.html?iref=allsearch

Gergen, D. (2013, January 19). Obama 2.0: Smarter, tougher - but wiser? Retrieved January 2013, 2013, from CNN: http://edition.cnn.com/2013/01/18/opinion/gergen-obamatwo/index.html?iref=allsearch

Gergen, D. (2013, January 23). Obama's historic speech deepens divisions. Retrieved January 24, 2013, from CNN: http://edition.cnn.com/2013/01/23/opinion/gergen-obamahistory/index.html?iref=allsearch

Gibbs, N. (2004, June 14). The All-American President. Time Magazine, pp. 28-41.

Goldman, R. (2012, October 2). Romney comes out swinging. Retrieved November 14, 2012, from ABC News: www.abcnews.go.com/politics/OTUS/mitt-romney-siwinging-presidential-debate

Granderson, L. (2012, November 8). Obama's critics, repudiated at last. Retrieved November 9 , 2012, from CNN: http://edition.cnn.com/2012/11/07/opinion/granderson-obamareelection/index.html?iref=allsearch 
Granderson, L. (2013, January 21). How Obama made opportunity real in America. Retrieved January 24, 2013, from CNN: http://edition.cnn.com/2013/01/21/opinion/granderson-obamachange/index.html?iref=allsearch

Greenberg, S. B. (1996). Middle Class Dreams: The Politics and Power of the New American Majority. New Haven : Yale University Press.

Greenstein, F. I. (2009). The Presidential Difference: Leadership Style from FDR to Barack Obama. Princeton: Princeton University Press.

Grunwald, M. (2009, January 26). One Trillion Dollars. Time Magazine, pp. 12-18.

Grunwald, M. (2012). The New New Deal: The Hidden Story of Change in the Obama Period. New York: Simon and Schuster.

Grunwald, M. (2012, November 19). Why the GOP will double down on a losing strategy. Time Magazine, pp. 74-77.

Hamby, P., Preston, M., \& Steinhauser, P. (2012, October 4). 5 things we learned from the presidential debate. Retrieved November 11, 2012, from CNN: http://edition.cnn.com/2012/10/04/politics/debate-5-thingslearned/index.html?iref=allsearch

Hamiltion, A. (1904). The Works of Alexander Hamilton (Vol. 10). (H. C. Lodge, Ed.) New York: Putman.

HaN, L. C. (2011). New Direction in the American Presidency. New York : Routledge.

Hargrove, E. C. (1998). The President as Leader: Appealing to the Better Angels of our Nature. Lawerence, Kansas: University Press of Kansas.

Hargrove, E. C. (2001). Presidential Power and Political Science. Presidential Studies Quarterly, 31(2), 245-261.

Hargrove, E. C. (June 2001). Presidential Power and Political Science. Presidential Studies Quarterly, 31(2), 245-261.

Harris, D. B. (Spring 1997). Dwight Eisenhower and the New Deal: The Politics of Preemption. Presidential Studies Quarterly, 27(2), 333-342.

Hayward, S. F. (2001). The Age of Reagan: The Fall of the Old Liberal Order 1964-1980. New York: Three Rivers Press.

Hayward, S. F. (2009). The Age of Reagan: The Conservative Counterrevolution 1980-1989. New York: Three Rivers Press.

Heclo, H. (2008). The Mixed Legacies of Ronald Reagan. Presidential Studies Quarterly, 38(4), 555574.

Heilemann, J., \& Halperin, M. (2010). Race of a Lifetime: How Obama won the White House. London: Viking Press. 
Hoekstra, D. J. (September 1999). The Politics of Politics: Skowronek and Presidential Research. Presidential Studies Quarterly, 29(3), 657-671.

Jacobs, L. R., \& Skocpol, T. (2010). Health Care Reform and American Politics. New York: Oxford University Press.

Jefferson, T. (1955). The Works of Thomas Jefferson. (P. L. Ford, Ed.) New York: Putnum.

Johansson, J. (2005). Two Titans: Muldoon, Lange and Leadership. Wellington: Dunmore Publishing.

Johansson, J. (2009). The Politics of Possibility: Leadership in Changing Times. Wellington: Dunmore Publishing.

Johansson, J. (2010). Obama In Political Time: Presidential Leadership in the 21st Century. Fulbright Speech.

Johansson, J. (2012, November 3-9). Across the great divide. New Zealand Listener, pp. 20-25.

Johnson, L. B. (1966). Pulbic Papers of the Presidents: Lyndon Baines Johnson. Washington DC: Government Printing Office.

Jones, V. (2013, January 23). Obama Speech: Anti-government era is over. Retrieved January 24, 2013, from CNN: http://edition.cnn.com/2013/01/22/opinion/jones-obamaspeech/index.html?iref=allsearch

Jr, P. F. (2004). Presidential Campaigns: From George Washington to George W. Bush. New York: Oxford University Press.

Jr., A. M. (1999). The Cycles of American History. New York: Mariner Books.

Kahn, J. (2004, June 8). Ronald Reagan launched his political career using Berkeley campus as a target. Retrieved April 22, 2012, from Berkeley: http://www.berkeley.edu/news/media/releases/2004/06/08_reagan.shtml

Kamarck, E. (2012, November 7). Five things Obama must do. Retrieved November 9, 2012, from CNN: http://edition.cnn.com/2012/11/07/opinion/kamarck-fivethings/index.html?iref=allsearch

Kaye, A. (2013, February 1). Reagan is not the solution to the GOP's Problem; Reagan is the Problem. Retrieved February 5, 2013, from US News: http://www.usnews.com/opinion/blogs/ansonkaye/2013/02/01/ronald-reagan-is-the-gops-problem-not-its-solution_print.html

Kennedy, D. M. (2012, November 7). Obama's victory won't transform America. Retrieved November 9, 2012, from CNN: http://edition.cnn.com/2012/11/07/opinion/kennedy-obamavictory/index.html?iref=allsearch

Kennedy, E. M. (2009). True Compass. London: Little Brown.

Killough, A. (2012, July 21). Team Obama: Romney trip and 'embarrassing disaster'. Retrieved November 14, 2012, from CNN: http://politicalticker.blogs.cnn.com/2012/07/31/teamobama-romney-trip-an-embarrassing-disaster/?iref=allsearch 
King, J. (2012, September 19). King: For Romney, how bad is this? Retrieved November 14, 2012, from CNN: http://edition.cnn.com/2012/09/18/politics/king-romney-how-bad/index.html

Klaidman, D. (2012, November 19). The Fortunate One. Newsweek, pp. 28-33.

Klein, J. (2009, May 4). The Rock Builder. Time Magazine, pp. 16-19.

Klein, J. (2012, November 19). Obama's Mandate for Moderation. Time Magazine, pp. 27-29.

Kloppenberg, J. T. (2011). Reagan Obama: Dreams, Hope, and the American Political Tradition. Princeton: Princeton University Press.

Kovaleski, S. (2008, July 7). Obama's Organizing Years, Guiding Others and Finding Himself. Retrieved April 7, 2012, from The New York Times:

http://www.nytimes.com/2008/07/07/us/politics/07community.html?pagewanted=all\&_r= 0

Krauthammer, C. (2013, January 24). Obama unbound - our president wants to undo everything Reagan ever did. Retrieved February 5, 2013, from Fox News:

http://www.foxnews.com/opinion/2013/01/24/obama-unbound-our-president-wants-toundo-everything-reagan-ever-did/

Kuhn, D. P. (2009, October 14). Like Obama, Reagan was adored by his Party's base. Retrieved May 27, 2011, from Real Clear Politics:

www.realclearpolitics.com/articles/2009/10/14/like_obama_reagan_was_adored_by_his_p artys_base.html

Laing, M. (April 2012). Towards a Pragmatic Presidency? Exploring the Waning of Political Time. Polity, 44(2), 234-259.

Library of Congress. (2009). My Fellow Americans: Presidential Inaugural Addresses From Geogre Washington to Barack Obama. St Petersburg, Florida: Red and Black Publishers.

Logan, E. (2011). At this Defining Moment. New York: New York University Press.

Lothian, D., Yellin, J., \& Cohen, T. (2013, January 29). Now is the time to move on immigration, Obama says. Retrieved January 30, 2013, from CNN:

http://edition.cnn.com/2013/01/29/politics/immigration-reform/index.html?iref=allsearch

Lotian, D., Yellin, J., \& Cohen, T. (2013, January 29). Now's the time to move on Immigration Reform. Retrieved February 4, 2013, from CNN:

http://edition.cnn.com/2013/01/29/politics/immigration-reform/index.html?iref=allsearch

Manners, A. (2010, December 6). Reviewing "Presidential Leadership in Political Time". Retrieved September 1, 2011, from Veep Critique:

http://veepcritique.blogspot.co.nz/2010/12/reviewing-presidential-leadership-in.html

Mardell, M. (2012, July 27). Boris Johnson chides Mitt Romney over London Olympics. Retrieved November 16, 2012, from BBC News: http://www.bbc.co.uk/news/world-us-canada19007127 
Mayer, J., \& McManus, D. (1988). Landslide: The Unmaking of the President 1984-1988. London: Collins Press.

Mieczkowski, Y. (2001). The Routledge Historical Atlas of Presidential Elections. London: Routledge.

Milkis, S. M. (Spring 1995). What Politics do Presidents Make? Polity, 17(3), 485-534.

Milkis, S. M., \& Nelson, M. (2008). The American Presidency Origins and Development 1776-2007. Washington DC: CQ Press.

Miller. (2010). Andrew Jackson: Impact and Legacy. Retrieved January 13, 2012, from Miller Centre: http://millercentre.org/president/jackson/essays/biography/9

Miller, M. (2012, November 7). Obamacare gets its vindication. Retrieved November 9, 2012, from The Washington Post: http://www.washingtonpost.com/opinions/matt-miller-obamacare-isvindicated/2012/11/07/2a33b842-28a5-11e2-bab2-eda299503684_story.html

Monticello. (2010). Brief Biography of Thomas Jefferson. Retrieved January 1, 2012, from Monticello: http://www.monticello.org/site/jefferson/brief-biography-thomas-jefferson

Morris, D. (2010, October 20). The New Republican Right. Retrieved April 28, 2012, from Real Clear Politics:

http://www.realclearpolitics.com/articles/2010/10/20/the_new_republican_right_107653.h tml

Morris, E. (1999). Dutch: A Memoir of Ronald Reagan. London: HarperCollins.

Moser, B. (2012, November 7). Obama Wins the Future. Retrieved November 9, 2012, from The American Future: http://prospect.org/article/obama-wins-future

MSNBC. (n.d.). Senator Kennedy Endorses Obama. Retrieved October 2010, 2012, from MSNBC 2008 Election News: http://msnbc.msn.com/id/22873162/nz/politics-decision_08/t/sen-kennedyendorses-barack-obama/

Murray, S. (2008, January 17). Obama's Reagan Comparison Sparks Debate. Retrieved November 24, 2012, from Washington Post: http://voices.washingtonpost.com/44/2008/01/obamasreagan-comparison-spark-1.html

National Museum of American History. (n.d.). Abraham Lincoln . Retrieved February 27, 2013, from National Museum of American History: http://americanhistory.si.edu/presidency/timeline/pres_era/3_677.html

Navarrette, R. (2012, November 10). How GOP can attract Latino voters. Retrieved November 20, 2012, from CNN: http://edition.cnn.com/2012/11/09/opinion/navarrette-latinovote/index.html?iref=allsearch

Nelson, M. (2010, March 28). Neustadt's Presidential Power at 50. Retrieved March 14, 2012, from The Chronicle of Higher Education: http://chronicle.com/article/NeustadtPresidential/64816/

Neustadt, R. E. (1990). Presidential Power and the Modern Presidents. New York: The Free Press. 
Nichols, C., \& Myers, A. S. (2010). Exploiting the Opportunity for Reconstructive Leadership: Presidential Responses to Enervated Political Regimes. American Politics Research, 38(5), 806-841.

Noonan, P. (2001). When Character was King: A Story of Ronald Reagan. New York: Pengiun Books.

Noorani, A. (2012, November 9). Both parties must lead on immigration. Retrieved November 20, 2012, from CNN: http://edition.cnn.com/2012/11/08/opinion/noorani-immigrationelection/index.html?iref=allsearch

Obama for America. (2012). The President's Record on Job Creation. Retrieved October 26, 2012, from Barack Obama: http://www.barackobama.com/record/economy?source-footer-nav

Obama, B. (1995). Dreams from My Father. New York: Three Rivers Press.

Obama, B. (2006). The Audacity of Hope. New York: Random House.

Obama, B. (2008, March 18). A More Perfect Union. Retrieved October 16, 2012, from Barack Obama: http://www.barackobama.com/2008/03/18/remarks_of_Senator_barack_obama_53.php

Obama, B. (2008). Change We Can Believe in - Barack Obama's Plan to Renew America's Promise. New York: Three Rivers Press.

Obama, B. (2009, June 4). Obama's Speech in Cairo. Retrieved April 28, 2012, from The New York Times:

http://www.nytimes.com/2009/06/04/us/politics/04obama.text.html?pagewanted=all

Obama, B. (2009, January 21). President Obama's Inaugural Address. Retrieved March 5, 2013, from White House: http://www.whitehouse.gov/blog/inaugural-address/

Obama, B. (2011, February 28). Dedication to Ronald Wilson Reagan. USA Today: Special Centennial Edition - Reagan an American Icon, p. 29.

Obama, B. (2012, November 7). Remarks by the President on Election Night. Retrieved November 9, 2012, from White House: http://www.whitehouse.gov/the-pressoffice/2012/11/07/remarks-president-election-night

Obama, B. (2012, November 7). Remarks by the President on Election Night. Retrieved November 9, 2012, from White House: www.whitehouse.govt/the-press-office/2012/11/07/remarkspresident-election-night

Obama, B. (2013, January 29). Fixing Our Broken Immigration System so Everyone Plays by the Rules. Retrieved February 4, 2013, from White House: http://www.whitehouse.gov/the-pressoffice/2013/01/29/fact-sheet-fixing-our-broken-immigration-system-so-everyone-playsrules

Obama, B. (2013, January 21). Inaugural Address by President Barack Obama. Retrieved January 22, 2013, from White House: http://www.whitehouse.gov/the-press-

office/2013/01/21/inaugural-address-president-barack-obama 
Obama, B. (2013, January 21). Inaugural Address by President Barack Obama. Retrieved January 27, 2013, from White House: http://www.whitehouse.gov/the-pressoffice/2013/01/21/inaugural-address-president-barack-obama

Obama, B. (2013, January 16). Now is the Time. Retrieved February 4, 2013, from White House: http://www.whitehouse.gov/sites/default/files/docs/wh_now_is_the_time_full.pdf

Our Campaigns. (n.d.). 1984 Democratic Primaries. Retrieved October 17, 2012, from Our Campaigns: http://www.ourcampaigns.com/RaceDetail.html?RacelD=55208

Pallasch, A. M. (2008, March 16). Obama Denounces Rhetoric But Stands Behind his Pastor. Retrieved October 16, 2012, from Chicago Sun Times: http://www.suntimes.com/news/politics/obama/844447,CST-NWS-wright15.article

PBS. (2008). Online News House - Reagan Biography. Retrieved April 22, 2012, from PBS: http://www.pbs.org/newshour/biography_pages/reagan/biography.html

Phillips, K. (2008, January 8). The Clinton Camp Unbound. Retrieved October 16, 2012, from The Caucus Blog - New York Times: http://thecaucus.blogs.nytimes.com/2008/01/08/theclinton-camp-unbound/

Pika, J. A., \& Maltese, J. A. (2010). The Politics of the Presidency: Revised Seventh Edition. Washington DC: CQ Press.

Pios, R. M. (1994). Book Review: The Politics Presidents Make: Leadership from John Adams to George Bush. Political Science Quarterly, 109(1), 171-174.

Plouffe, D. (2009). The Audacity to Win. London : Viking Group.

Polling, G. (2011). Presidential Job Approval Centre. Retrieved December 28, 2011, from Gallup: http://www.gallup.com/poll/124922/presidential-approval-center.aspx

Rasmussen Reports. (2010). Health Care Law. Retrieved November 5, 2012, from Rasmussen: http://www.rasmussenreports.com/public_content/politics/current_events/healthcare/heal th_care_law

Reagan, R. (1990). An American Life. New York: Simon \& Schuster.

Reagan, R. (1990). Speaking My Mind: Selected Speeches. London: Hutchinson.

Reagan, R. (2008, June 1). A Time For Choosing Speech. Retrieved April 22, 2012, from Reagan Foundation: http://www.reaganfoundation.org

Remnick, D. (2010). The Bridge: The Life and Rise of Barack Obama. New York: Picador.

Renshon, S. A. (2012). Barack Obama and the Politics of Redemption. New York: Routledge.

Rich, F. (2012, November 9). Fantasyland: Denial has poisoned the GOP and threatens the rest of the country too. Retrieved November 12, 2012, from New York Magazine: http://nymag.com/news/frank-rich/gop-denial-2012-11/ 
Rockman, B. A., Rudalevige, A., \& Campbell, C. (2012). The Obama Presidency - Appraisals and Prospects. Washington DC: CQ Press.

Roosevelt, F. D. (1938-1950). The Public Papers and Addresses of Franklin D. Roosevelt. (S. I. Rosenman, Ed.) New York: Random House.

Rothkopf, D. (2013, January 22). Obama's America, better than what Founders imagined. Retrieved January 24, 2013, from CNN: http://edition.cnn.com/2013/01/21/opinion/rothkopf-betteramerica/index.html?iref=allsearch

Sabato, L. J. (2010). The Year of Obama: How Barack Obama won the White House. New York: Longman Pearson.

Scherer , M., \& Duffy, M. (2011, February 7). The Role Model. Time Magazine, pp. 12-17.

Scherer, M. (2012, December 31). 2012 Person of the Year: Barack Obama. Time Magazine, pp. 2453.

Schier, S. E. (2011). Barack Obama in the White House: Transforming America. Lanham, Maryland: Rowman \& Littlefield Publishers.

Shirley, C. (2005). Reagan's Revolution: The Untold Story of the Campaigned that Started it all. Nashville: Nelson Current.

Shirley, C. (2010). Rendezvous with Destiny: Ronald Reagan and the Campaign that Changed America. Wilmington: ISI Books.

Silverleib, A. (2012, November 7). Analysis: Obama's new Democratic majority. Retrieved November 9, 2012, from CNN: http://edition.cnn.com/2012/11/07/politics/exit-pollsanalysis/index.html?iref=allsearch

Silverleib, A. (2012, March 8). Super Tuesday. Retrieved November 23, 2012, from CNN: www.cnn.com/2012/03/06/politics/super-tuesday/index.html

Sinderbrand, R. (2012, November 7). Analysis: Obama won with a better ground game. Retrieved November 9, 2012, from CNN: http://edition.cnn.com/2012/11/07/politics/analysis-whyobama-won/index.html?iref=allsearch

Skocpol, T. (2012). Obama and America's Political Future. Cambridge: Harvard University Press.

Skocpol, T., \& Jacobs, L. R. (2011). Reaching for a New Deal. New York: Russell Sage Foundation.

Skocpol, T., \& Williamson, V. (2012). The Tea Party and the remaking of Republican Conservatism. New York: Oxford University Press.

Skowronek, S. (1997). The Politics Presidents Mate: Leadership from John Adams to Bill Clinton. Cambridge: Harvard Universtiy Press.

Skowronek, S. (2011). Presidential Leadership in Political Time: Reprise and Reappraisal. Lawerence, Kansas: University Press of Kansas. 
Skowronek, S. (Spring 1995). Response. Polity, 27(3), 517-534.

Smith, R. N. (2011, February 7). The Reagan Revelation. Time Magazine, pp. 18-21.

Stanley, T. (2012, November 7). Romney couldn't overcome contradictions. Retrieved November 11, 2012, from CNN: http://edition.cnn.com/2012/11/07/opinion/stanley-romneyhistory/index.html?iref=allsearch

Steinhauser, P. (2012, October 30). 5 things to watch in hurricane-wracked campaign. Retrieved October 14, 2012, from CNN: http://edition.cnn.com/2012/10/29/politics/sandy-politics-5things/index.html?iref=allsearch

Steinhauser, P. (2012, November 8). Five things we learned on Election Night. Retrieved November 11, 2012, from CNN: http://edition.cnn.com/2012/11/07/politics/5-things-electionnight/index.html?iref=allsearch

Stengel, R., Scherer, M., \& Jones, R. (2012, December 19). Setting the Stage for a Second Term. Retrieved December 20, 2012, from Time Magazine: http://poy.time.com/2012/12/19/setting-the-stage-for-a-second-term/\#ixzz2Fk5ZOE4E

Stewart, G. (2013, January 22). Obama finally meets Machiavelli. Retrieved January 24, 2013, from CNN: http://edition.cnn.com/2013/01/21/opinion/stewart-obama-inauguralspeech/index.html?iref=allsearch

Stuckey, M. (Fall 2000). The Presidecy and Political Leadership. Rhetoric and Public Affairs, 3, 452454.

The American Presidency Project. (2008, January 5). Democratic Presidential Candidates Debate in Manchester, New Hampshire. Retrieved October 16, 2012, from The American Presidency Project: http://www.presidency.ucsb.edu/ws/index.php?pid=76224

The New York Times. (2010, August 31). President Obama's Address on Iraq. Retrieved April 28, 2012, from The New York Times: http://www.nytimes.com/2010/09/01/world/01obamatext.html?_r=1\&pagewanted=1\&ref=world

The New York Times. (n.d.). State By State Primary Results. Retrieved November 23, 2012, from The New York Times: www.nytimes.com/2012/primaries/calendar.html

Thomas, G. (2008). Yes We Can - A Biography of Barack Obama. New York: Fiewel and Friends.

Thurber, J. A. (2011). Obama in Office. Boulder: Paradigm Publishers.

Todd, C., \& Gawiser, S. (2009). How Barack Obama Won: A State-by-state Guide to the Historic 2008 Presidential Election. New York: Vintage Books.

Troy, G. (2005). Morning in America. Princeton: Princeton University Press.

Tulis, J. K. (1987). The Rhetorical Presidency. Princeton: Princeton University Press.

Tygiel, J. (2006). Ronald Reagan and the Triumph of American Conservatism. New York: Pearson Longman. 
United States Government. (2009). About the Recovery Act. Retrieved April 28, 2012, from Recovery: http://www.recorvery.gov/About/Pages/The_Act.aspx

United States Government. (2009). How the Funds are Allocated. Retrieved April 28, 2008, from Recovery Act: http://www.recovery.gov/Transparency/fundingoverview/pages/fundingbreakdown.aspx

US Election Atlas. (n.d.). 1980 Presidential Election Results. Retrieved October 4, 2012, from US Election Atlas: http://uselectionatlas.org/RESULTS/

Valelly, R. (2003, October 31). An Overlooked Theory on Presidential Politics. Retrieved September 1, 2011, from The Chronicle of Higher Education: www.umn.edu/pre/law/articles_advice/PoliSci_Overlooked.htm

Von Drehle, D. (2012, November 19). For Obama, Survival is the new Winning. Time Magazine, pp. 32-39.

Waddan, D. B. (2006). The Social Policies Presidents Make: Pre-Emptive Leadership Under Nixon and Clinton. Political Studies, 54, 65-83.

Wayne, S. J. (2011). Presidential Character and Judgment: Obama's Afganistan and Health Care Decisions. Presidential Studies Quarterly, 41(2), 291-306.

White, J. K. (2012). Barack obama's America: How New Conceptions of Race, Family and Religion ended the Reagan Era. Ann Arbor: University of Michigan Press.

Whitney, D. C. (2009). The American Presidents. New York: Reader's Digest.

Wilmerding Jr, L. (December 1960). Presidential Power: The Politics of Leadership - Review. Political Science Quarterly, 75(4), 597-599.

Wirthlin, D. (2004). The Greatest Communicator: What Ronald Reagan taught me about Politics, Leadership and Life. Hoboken: Wiley.

Wolffe, R. (2009). Renegade: The Making of Barack Obama. London: Virgin Books.

Young, J. S. (Spring 1995). Power and Purpose in The Politics Presidents Make. Polity, 509-516.

Zakaria, F. (2012, January 19). Obama the Strategist. Retrieved April 28, 2012, from Global Public Square: http://globalpublicsquare.blogs.cnn.com/2012/01/19/zakaria-obama-thestrategist/?iref=allsearch

Zakaria, F. (2012, January 30). The Strategist. Time Magazine, pp. 14-23.

Zeleny, J. (2012, January 10). Romney wins GOP Primary in New Hampshire. Retrieved November 23, 2012, from The New York Times: www.nytimes.com/2012/01/11/us/politics/mitt-romneywins-in-new-hampshire-republican-primary.html

Zelizer, J. (2012, November 12). How progress is possible in Obama's second term. Retrieved November 20, 2012, from CNN: http://edition.cnn.com/2012/11/12/opinion/zelizer-obamaprogress/index.html?iref=allsearch 
Zelizer, J. (2012, October 29). How Sandy will test Obama, Romney. Retrieved November 14, 2012, from CNN: http://edition.cnn.com/2012/10/29/opinion/zelizer-weathercampaign/index.html?iref=allsearch

Zelizer, J. (2013, January 21). Obama's speech: Learning from Lincoln, Wilson, FDR. Retrieved January 22, 2013, from CNN: http://edition.cnn.com/2013/01/20/opinion/zelizer-obamaspeech/index.html?iref=allsearch

Zernike, K. (2012, October 31). One Result of Hurricane: Bipartisanship Flows. Retrieved November 14, 2012, from The New York Times: http://www.nytimes.com/2012/11/01/nyregion/instunning-about-face-chris-christie-heaps-praise-on-obama.html 